UNITED STATES DEPARTMENT OF THE INTERIOR

Harold L. Ickes, Secretary

U. GEOLOGICAL SURVEY

W. C. Mendenhall, Director

\title{
Bulletin 926
}

\section{MINERAL RESOURCES \\ OF ALASKA}

\section{REPORT ON PROGRESS OF INVESTIGATIONS IN 1939}

\author{
PAPERS BY
}

PHILIP S. SMITH, FRED H. MOFFIT AND F. F. BARNES

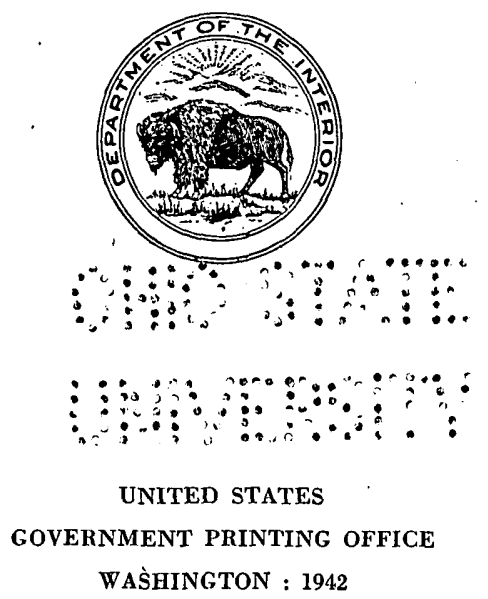


Os

ice

16. 220

Copy\%

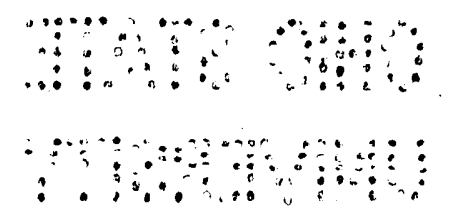




\section{CONTENTS}

[The letters in parentheses preceding the titles are those used to designate the papers for advance publication]

(A) Mineral industry of Alaska in 1939, by Philip S. Smith.

(B) Geology of the Gerstle River district, Alaska, with a report on the Black Rapids Glacier, by Fred H. Moffit.

(C) Occurences of molybdenum minerals in Alaska, by Philip S. Smith ...

(D) Geology of the Portage Pass area, Alaska, by F. F. Barnes.......

\section{ILLUSTRATIONS}

Plate 1. Map of Alaska, showing areas covered by selected available reports and maps of Alaska.......................... In pocket

2. Topographic reconnaissance map of the Gerstle River district, Alaska.... . . . . . . . . . . . .

3. Geologic reconnaissance map of the Gerstle River district. In pocket

4. View southeast across Jarvis Creek Glacier from mountain top 3 miles east of Rapids Roadhouse.

5. $A$, Smooth, round-topped mountains east of Johnson River near northern border of highland area; $B$, Donnelly Dome from a point 3 miles to the southwest ....................

6. $A$, Bed of white quartz fragments at base of Tertiary coalbearing deposits near head of Little Gold Creek; $B$, White quartz bed that forms base of Tertiary deposits near head of Little Gold Creek

7. $A$, Beds of coal in sandstone and sandy shale on small tributary of Jarvis Creek west of Little Gold Creek; $B$, Nenana gravel on Macomber Creek a short distance below mouth of Old Channel Creek . 
Plate 13. Regional map showing general relations of Portage Pass area,

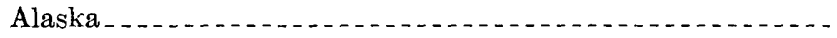

14. A, East slope of Portage Shoulder from head of Passage Canal; $B$, View west from Portage Shoulder down Portage Valley - -

15. South slope of Portage Shoulder.....

16. Geologic map of the Portage Pass area . . . . . . . . . .

17. $A$, Breccial of argillite fragments in matrix of graywacke on west slope of Portage Shoulder; $B$, Lower part of Portage Glacier, from Turnagain Shoulder

18. Névé fields and upper part of Portage Glacier, from Portage Shoulder

19. Whittier Glacier, as seen from Passage Canal: $A$, In 1914; $B$, In 1940

20. View across head of Passage Canal from the southeast, showing J.earnard Glacier: $A$, In $1914 ; B$, In 1940

21. $A$, Debris-covered ice ridges below Learnard Glacier, as seen from foot of Portage Shoulder in 1914; $B$, West slope of Portage Shoulder, showing large fold in beds of slate and graywacke.

Figure 1. Trends of mineral production of Alaska, 1890-1939

2. Trend of value of gold production of Alaska, 1880-1939 . . . .

3. Copper produced from Alaska mines, 1900-1939, and fluctuations in the price of copper during that period.

4. Index map of part of Alaska showing the location of the Gerstle River district.

5. Map of drainage basin of Black Rapids Glacier as surveyed by J. W. Bagley in 1910

6. Lower part of Black Rapids Glacier as surveyed by T. W. Ranta in 1937

7. Index map showing location of Portage Pass area......... 
UNITED STATES DEPARTMENT OF THE INTERIOR

Harold L. Ickes, Secretary

GEOLOGICAL SURVEY

W. C. Mendenhall, Director

\section{Bulletin 926-A}

\section{MINERAL INDUSTRY OF ALASKA IN 1939}

BY

PHILIP S. SMITH

Mineral Resources of Alaska, 1939

(Pages 1-97)

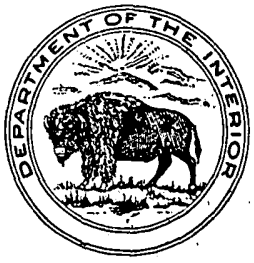

UNITED STATES

GOVERNMEN'T PRINTING OFFICE

WASHINGTON : 1941 



\section{CONTENTS}

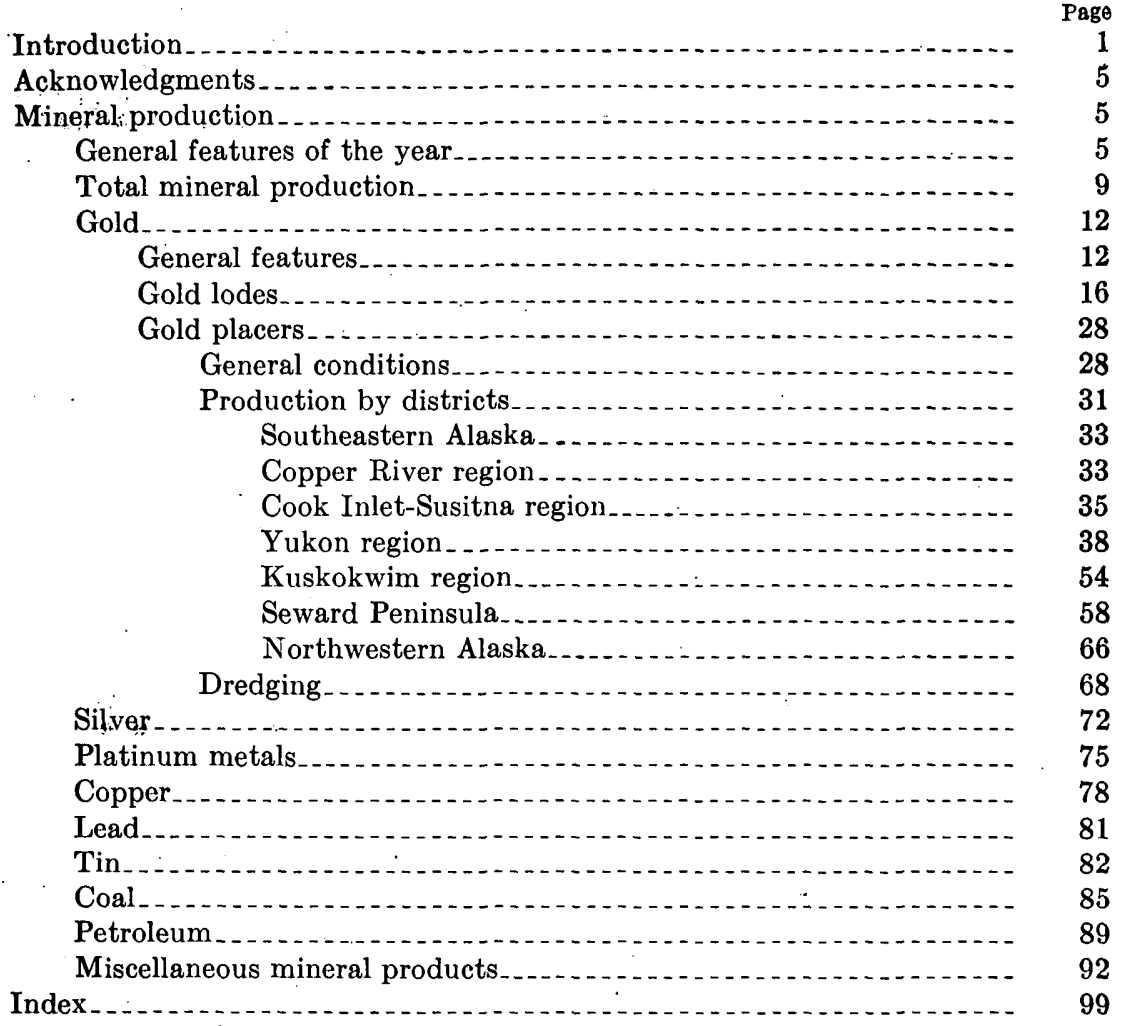

Selected list of Geological Survey publications on Alaska_ On back of map in pocket

\section{ILLUSTRATIONS}

Plate 1. Map of Alaska, showing areas covered by selected available reports and maps of Alaska...........................

FigdRE 1. Trends of mineral production of Alaska, 1890-1939

2. Trend of value of gold production of Alaska, 1880-1939..... 14

3. Copper produced from Alaska mines, 1900-1939, and fluctuations in the price of copper during that period 


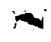

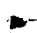

$\lambda$

$\sim$

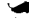

$j$

A 


\title{
MINERAL INDUSTRY OF ALASKA IN 1939
}

\author{
By Philip S. Smith ${ }^{1}$
}

\section{INTRODUCTION}

The presentation of a yearly record of the Alaska mineral industry is a continuing service that has been rendered by the Geological Survey from almost the earliest years of extensive mining in Alaska, and the present report, for 1939, is the thirty-sixth of this series. ${ }^{2}$ Such a record, especially when supplemented by the statistics for the preceding years, not only affords an authoritative summary of current and past conditions but also indicates trends that are of significance in suggesting the lines along which future developments of the industry are likely to proceed. These reports therefore serve miners, prospectors, and businessmen concerned with Alaska affairs as useful historical records, statements of contemporary conditions, and starting points on which some conjectures concerning future operations may be predicated.

To obtain the information recorded in these reports the Geological Survey, in addition to its other investigations of mineral resources, conducts an annual canvass of the entire mineral industry of Alaska. The collection of the facts requisite for the preparation of these annual statements involves difficulties, because the great size of the Territory, the diversity of its mineral products, and the large number but small size of many of the enterprises make it impracticable without undue delay and expense to gather all the desired information at first hand. The information used is therefore derived from many sources, which necessarily vary in reliability and completeness. Efforts are made, however, to reduce all the statements to a comparable basis and to

\footnotetext{
1 The canvass of producers, the tabulation of their replies, and general assistance in all phases of the office work connected with the preparation of the statistics set forth in this report have been carried through effectively by Kathleen S. Waldron, of the Alaskan branch of the Geological Survey.

2 The other volumes of this series, commencing with that for 1904 , are Bulletins 259 , $284,314,345,379,442,480,520,542,392,622,642,662,692,712,722,739,755,773$, $783,792,810,813,824,836,844-A, 857-A, 864-A, 868-A, 880-A, 897-A, 910-A$, and 917-A. The reports for 1902 and 1903 were included with other "contributions to economic geology" in Bulletins 213 and 225 .
} 
give only those that appear to be well substantiated. Among the most reliable sources of information are the geologists and engineers who are sent out each year by the Geological Survey to conduct surveys in different parts of Alaska and who acquire not only much accurate information regarding the mineral production of the regions in which they work but also general information by contact with miners and operators in the course of their travels to and from the field. Members of other Government organizations-for instance, the Bureau of Mines, the Bureau of the Mint, The Alaska Railroad, the Bureau of Foreign and Domestic Commerce, and the Customs Service-in the course of their regular duties collect many data which are extremely valuable in these studies and the use of which avoids unnecessary duplication in collecting records. Most of the banks, express companies, and other business organizations in Alaska collect for their own use data regarding mineral commodities of their particular districts. Some of these data are extremely pertinent to the general inquiry conducted by the Geological Survey, and through the cordial cooperation of many of these companies important facts have been made available to the Survey, though some of this information is confidential and is not released for publication. Most of the larger Alaska newspapers and certain papers published in the States that feature Alaska matters are courteously sent by their publishers to the Geological Survey, and from these and the technical and scientific periodicals are gleaned many items regarding new developments.

In addition to all these general sources, the Geological Survey each year sends out hundreds of schedules-one to every person or company known to be engaged in mining in Alaska-on which are questions regarding the mining developments and production of each individual property during the year. These schedules, when filled out by the operators, constitute a most authoritative record. Unfortunately, however, not all of them are returned by the operators, and even some of the operators who return them have not all the specific data desired, misunderstand the inquiries, or reply in such a manner that the answers may not be correctly interpreted when the schedules are edited. It is gratifying evidence of the general appreciation of these annual summaries that so many of the operators cooperate fully and cordially with the Geological Survey by furnishing the information called for on the schedules as well as volunteering much other pertinent information.

It is apparent, however, that facts collected from one source, although of themselves strictly accurate, are likely to be computed or stated on a different basis from equally reliable reports received from another source, so that considerable editing and revision must be 
done to bring all to one standard. It is not possible to know exactly all the corrections that should be applied in order to reduce the reports of production to a strictly uniform standard. However, though some uncertainties necessarily remain, it is believed that they do not have significant effect on the results expressed and that the report is consistent within itself and with the other reports of this series which record the statistics of mineral production.

The restriction of the statistics in this report to those relating to production should be stressed, so that the reader will realize that while the statistics are comparable among themselves, they necessarily differ from those published by some of the other Government bureaus, because these are primarily records of production, whereas those issued by the Bureau of the Mint, for instance, relate to receipts at the offices of that Bureau, those issued by the Customs Service relate to shipments recorded at its stations, and those issued by other organizations may be computed on still other bases. The term "production," however, is rather indefinite because it may refer to the raw ore as it is broken from the ledge, or the metal content of the placer gravel before it has been sluiced, or it may be applied to any of the later stages that intervene before the final product is disposed of in usable form. Thus, the miner produced so much ore, the millman so much concentrates, the smelter so much metal of. varying degrees of purity, the refiner so much pure metal. Between each of these stages there are inevitable losses of the valuable metals contained in the material treated, so that at no two stages is the amount "produced" the same. The cost would far exceed the value of the results for the Geological Survey to attempt to collect records as to the quantities of the different mineral commodities produced at each of these several stages. Consequently, it has been necessary to adopt the stage that seemed to represent one of the common determinable and significant steps. . For most materials this has been considered to be the stage when the true recoverable content of valuable minerals can be closely determined and the material is in shape to be disposed of on that basis. In other words, the metals contained in the rock but lost in the tailings would not be considered "produced," but ore mined, though not milled or smelted, would be credited with the metallic content that could reasonably be expected to be recovered from it after such treatments. Unless there are obvious inconsistencies the individual reports showing the quantities of minerals produced are accepted as final.

Much difference between statements from different sources arises also through various methods of computing the value of the different mineral commodities. It has been the standard practice in 
these volumes to base all computations of values on the average selling price for the year and not on the prices actually received by the individual producers. Obviously, this method of computation dis-regards the amount received by individual mines, but it is believed to afford a more useful representation of the industry as a whole. Thus the reports of the operators of small placer mines, who sold their gold at a discount in local trade, or those of the larger producers, who may have made deductions for shipping, insurance, and other expenses incident to handling their product, were so edited that the full value of the gold produced was recorded. Because of this method of computing the values of the different commodities, if for no other reason, the statistics necessarily differ greatly from those that might be collected for tax or similar purposes.

It is the constant aim of the compilers to make these annual summaries of mineral production as helpful, accurate, and adequate as possible. The Geological Survey therefore bespeaks the continued cooperation of all persons concerned in the Alaska mineral industry and urges them to communicate any information that may lead to this desired end. It should be emphasized that facts relating to individual properties are regarded as strictly confidential. The Geological Survey does not use any information that is furnished in a way that will disclose the production of individual plants, nor allow access to its records in any way disadvantageous either to the individuals who furnish the information or those to whom it relates. So scrupulously is this policy followed that in this volume it has been necesșary to combine or group together certain districts or products so that the production of an individual may not be disclosed.

The foregoing statements, emphasizing as they do the scope and contents of these ainnual summaries of the mineral industry of Alaska, should not cause the reader to overlook the fact that these annual summaries contribute but part of the service the Geological Survey furnishes the public regarding Alaska. Indeed the greater part of the publications of the Geological Survey on Alaska describe in considerable detail the results of intensive examinations in the field by its technical staff of individual tracts of the Territory, such as specific mining camps or districts. Already several hundred such reports, illustrated by maps and pictures, have been issued to describe the topography, geology, and mineral deposits of the selected areas. In order that the more significant of these reports and maps that are available for sale or other distribution by the Government may be made known to those who may be interested, an index map, which shows graphically the areas covered by these publications, is included in this volume as plate 1 (in pocket). A list, by titles, is printed on the back of the map. 


\section{ACKNOWLEDGMENTS}

Among the private individuals and companies who have been especially courteous in supplying information of general significance outside that pertaining to their own operations may be mentioned the Alaska Weekly, the Mining World, and Volney Richmond, of the Northern Commercial Co., of Seattle, Wash., and the agents of this company, especially J. W. Farrell at Hot Springs and J. B. Knight at Eagle; Ralph and Carl Lomen, of Seattle and Nome; the Alaska Juneau Gold Mining Co., the Daily Alaska Empire, the B. M. Behrends Bank, J. J. Connors, and J. J. Hillard, of Juneau; Paul Sorensen of the Hirst-Chichagof Mining Co., of Kimshan Cove, and Jack Littlepage, of Chichagof; the Ketchikan Alaska Chronicle and the First National Bank, of Ketchikan; Sidney Anderson, of Hyder; the Cordova Daily Times, of Cordova; the First Bank of Valdez; Carl Whitham, of Chitina; Elwyn Swetmann and the Seward Weekly Gateway, of Seward; the Bank of Alaska, the First National Bank, W. E. Dunkle, Walter G. Culver, David Strandberg, the Anchorage Weekly Times, and A. A. Shonbeck, of Anchorage; B. H. Mayfield, of Talkeetna; Frank H. Waskey, of Dillingham; Charles Naughton, of Kodiak; A. W. Amero, of Beaver; the First National Bank, R. B. Earling and other officers of the Fairbanks Department of the United States Smelting, Refining \& Mining Co., the Fairbanks Daily News Miner, the Alaska Miner, and G. E. Jennings, of Fairbanks; John McCandlish, of Livengood; the Miners and Merchants Bank and Harry Donnelley, of Flat; Frank Speljack, of Ophir; J. W. Wick, of Russian Mission; J. L. Jean, of Goodnews Bay; Charles Johnston, of the Goodnews Bay Mining Co., of Platinum; the Nome Nugget, the Nome Department of the United States Smelting, Refining \& Mining Co., G. R. Jackson of the Miners and Merchants Bank of Alaska, and C. W. Thornton, of Nome; Arthur W. Johnson, of Haycock; E. M. Marx; of Teller; and Lewis Lloyd, of Shungnak.

\section{MINERAL PRODUCTION}

\section{GENERAL FEATURES OF THE YEAR}

The total value of the Alaska mineral production in 1939 was $\$ 25,296,000$. This was furnished by a number of different mineral products, but gold accounts for about 92 percent. Compared with the mineral production of 1938 , the output in 1939 was $\$ 3,311,000$, or about $111 / 2$ percent less. This decrease was due largely to the almost complete cessation of the copper-mining industry in Alaska, which in 1938 yielded copper worth nearly $\$ 3,000,000$. In comparing the mineral production of 1939 with that of 1938 it should be remembered that in 
1938 the Alaska production was exceedingly high, having been surpassed only in the 3 years of the World War, 1915-17, when unprecedented demand for certain war materials raised prices of mineral commodities far above normal.

The total production of minerals from the Territory in 1939 , as stated, reflects the complex interaction of many different factors, some favorable and others adverse; some affecting a single commodity and others applying to the industry as a whole. Those factors affecting a single kind of product will be discussed in later pages where the commodity in question is treated specifically. Here it is proposed to refer briefly to some of the factors that had general application.

Among the general conditions that affected the mining industry of Alaska as well as the rest of the world in 1939 was the general increase in prices of all mineral commodities, except gold, that prevailed that year as compared with 1938. The price of gold in the 2 years remained constant. As such a large share of the Alaska mineral production is supplied by gold, the slight increase in selling prices of the other mineral substances did not increase the "valuee "of the total "production of that year more than a few tens of thousands of dollars above what it would have been had the prices remained the same as they were in 1938.

Up to July 1, 1939, the price of silver that qualified for purchase by the Government under Executive order was 64.64 cents an ounce. After that date, by a later Executive order, the charge for services and seigniorage was decreased from 50 to 45 percent, with the result that the producer received somewhat more than 71 cents an ounce for his silver. The average price for the year of silver purchased by the Government was therefore approximately 67.9 cents. As apparently all Alaska silver was eligiblë for purchase by the Government under this order, the price thus set has been used in the computations in this report rather than 39.08 cents, which was the average price ${ }^{3}$ of silver that did not thus qualify. The average price of copper in 1939, according to the Bureau of Mines, was 10.4 cents a pound, and, according to the Engineering and Mining Journal, 10.965. These prices for copper may be contrasted with the price of 10 cents a pound that prevailed in 1938. During January 1939 the average price of copper was about 11 cents a pound, but it gradually declined until in June it was approximately 9.75 cents. Then, with the mounting disquiet in Europe, the price of copper steadily climbed until in October, November, and December it stood nearly stationary at approximately 12.25 cents. The

\footnotetext{
$\checkmark$ The prices quoted for the various mineral commodities in 1939 , unless otherwise stated, are based on statistics published by the Engineering and Mining Journal.
} 
average price of the platinum metals produced from Alaska mines in 1939 has been computed by the Geological Survey as $\$ 36.61$ an ounce, as compared with $\$ 35.71$ for 1938 . These prices for the platinum. metals differ somewhat from the average prices given by the Bureau of Mines or the Engineering and Mining Journal, because the diverse composition of the Alaska product is not the same as the average of the platinum metals from other sources. The general price for fine platinum in the States throughout the first 8 months of 1939 was fairly constant at $\$ 35$ a troy ounce, but for the last 4 months of that year it advanced to about $\$ 40$.

The general selling price of lead for the year, according to the Bureau of Mines, was about 4.7 cents a pound, or ${ }_{j}$ according to the Engineering and Mining Journal, about 5.05 cents. The trend in the selling price for lead during the year was in general comparable with that for copper in that during the early months there was a general decrease to May, after which date the price rose, until during the last 4 months it was practically stationary at the highest rate for the year.

Tin, which sold at an average price of 42.3 cents a pound during 1938, brought, according to the Engineering and Mining Journal, slightly more than 50 cents during 1939 . This average price resulted from a rather gradual increase in price during the first 8 months of the year, which was succeeded by a sudden rise to the high point of the year during September and a decrease during the last 3 months. The average selling price of antimony in 1939 was 12.36 cents a pound, as against 12.35 cents in 1938. During 1939, according to the Engineering and Mining Journal, there was a more or less continuous upward trend in the price of antimony, from about 11.25 cents a pound in February to 14 cents a pound during the last 3 months of the year. The price of Alaska coal is determined by local conditions, and in this report the average price adopted by the Geological Survey for 1939 has been taken as $\$ 4$ a ton, as against a price of $\$ 3.90$ for 1938 .

In general, labor conditions throughout the Territory were satisfactory during 1939. The strictly seasonal character of much of the employment in Alaska necessarily causes a heavy demand for competent workers during the summer, but this is followed by a heavy lay-off of personnel during the winter. This, however, is a well-recognized condition, so that it causes little disruption of the normal economics of the region, and those that do not fill continuing jobs either leave the Territory for the winter or employ that time in prospecting or in attending to their own affairs.

There were many signs. of increased interest in Alaskan developments that affected many lines of activities. The establishment of new Army 
and Navy bases at several widely separated areas attracted attention to the country and afforded new sources of employment. The favorable reports from the Government's colonization project near Matanuska corrected the erroneous impression formerly held by many that Alaska held no attractions of this sort for settlers. The low rates of interest that money commanded in enterprises in the States have led investors increasingly to look to Alaska as a promising field in which some of their funds may be utilized. Among such enterprises mining has received an especially large share of attention. The Government itself has done much, through the Reconstruction Finance Corporation, to assist in financing meritorious mining ventures, and, in addition to credits it had made heretofore, it approved in 1939 allocation of more than a million dollars for one of the projects in the Livengood district.

Certain of the minerals that have been mined at least intermittently in the past were not mined in 1939. For example, there was no production of petroleum products from the oil wells near Katalla or elsewhere in the Territory, no marble from the quarries on Prince of Wales Island in southeastern Alaska, and no chromite from the deposits in the southern part of Kenai Peninsula. To this list might be added a number of other mineral commodities that in the past have been mined from Alaska deposits. None of the deposits at the places specifically named have been exhausted, and the cessation of production from them is regarded as due solely to extraneous causes, which doubtless will not long prevail.

The foregoing outline of the general features of the year 1939 not only shows clearly that has the record for that year been good but also holds out encouraging prospects for the future. Although this optimism is probably very well justified, it seems desirable to interject a word of caution to those who might be carried away by the glamor that distance always gives to things with which we are not fully acquainted and who might thus be tempted to feel that Alaska is waiting to disclose its bounty to the chance seeker. Such dreamers should realize that for more than a third of a century hardy pioneers, who are at least somewhat experienced in mining, have toiled over most of the more accessible parts of Alaska, seeking its riches. A novice should therefore be warned that much more is required in finding a workable deposit than a mere desire for wealth, and that the chances of finding bonanza deposits that merely await the summons of the newcomer to disclose their treasures are extremely poor. It is expensive and not the job for a novice to get far off the beaten tracks in the search of new areas for prospecting. Although large parts of Alaska remain almost unknown and unexplored, other parts, especially those along 
the main avenues of communication, have lost most of their frontier characteristics, and their facilities compare favorably with those of many parts of the States proper. In many of these areas large, stable mining enterprises have already been built up, and there is the constant tendency to undertake operations on a larger scale than formerly, so that the unit cost of the work may be kept at a low figure. That mining may be done in parts of Alaska at an extremely low cost has been demonstrated by the past performances of many of its mines. This is especially true of one of its lode mines in southeastern Alaska, where costs are below those of any comparable enterprise in the world. This tendency to operate in larger units marks a distinct departure from the old days, when the search for mineral deposits was directed mainly toward the discovery of small rich deposits that could be worked by relatively crude methods and with little outlay of capital. Today, by far the larger part of all the mineral production of Alaska comes from mines utilizing extensive equipment to handle large volumes of relatively low-grade material. The modern prospector is therefore not limited in his search to small rich stringers or concentrations but may well direct his attention to finding deposits that appear to hold promise of yielding large quantities of average or even low-grade ore. Such a prospector, however, must realize that unless he has extensive technical or financial ability he is not fitted to carry through the development of such properties to a producing stage, and so if he places an excessive value on his discoveries he jeopardizes benefits to himself and to the mining industry, because the value of his service in finding a prospective deposit is usually but a small part of the heavy outlays and intricate planning that will be required for testing the property adequately and bringing it successfully into production.

In subsequent pages, in describing the individual mineral commodities, additional statements will be made as to specific factors that advanced or retarded certain developments in each of them, as well as general information given on the accomplishments during the year.

\section{TOTAL MINERAL PRODUCTION}

From the time of the earliest records of mining in Alaska to the end of 1939 minerals to the value of over $\$ 803,000,000$, or more than 111 times the purchase price of the Territory, have been produced by its mines. The distribution of this large total among the individual years is set forth in the following table and is graphically represented by the curves in figure 1. From this table and diagram it is evident that prior to 1899 the annual production ranged from negligible 
amounts to a maximum of less than $\$ 3,000,000$. After the discovery of the Canadian Klondike and the entrance of a swarm of prospectors and miners into Alaska the production quickly mounted, until in 1906 it reached a high point that marks the mining of many of the rich placers in the Nome and Fairbanks regions. For the next 8 years the annual production fluctuated somewhat but ranged around $\$ 20$,000,000 . Then it mounted by leaps until it reached a maximum of more than $\$ 48,000,000$ in 1916 . This rapid increase was due to the growth of copper production under the stimulus of the World War, when prices advanced to unprecedented heights. By 1919 the war stimulation was over, and the annual production from Alaska dropped again to about $\$ 20,000,000$. During the post-war period Alaska suffered through the fact that in the States scales of wages and opportunities for the employment of capital seemed to offer more advantages, and as a result there was more or less fluctuation in the mineral output. Between 1929 and 1933 production dropped from $\$ 16,000,000$ to slightly more than $\$ 10,000,000$. In 1934 , owing largely to the advance in the price of gold, it approached $\$ 17,000,000$, and later, with the continued high price of gold and general stimulation of mining, it has swiftly mounted to the high point in 1938 of over $\$ 28,600,000$ and has averaged nearly $\$ 25,000,000$ a year.

Value of total mineral production of Alaska, by years, 1880-1939

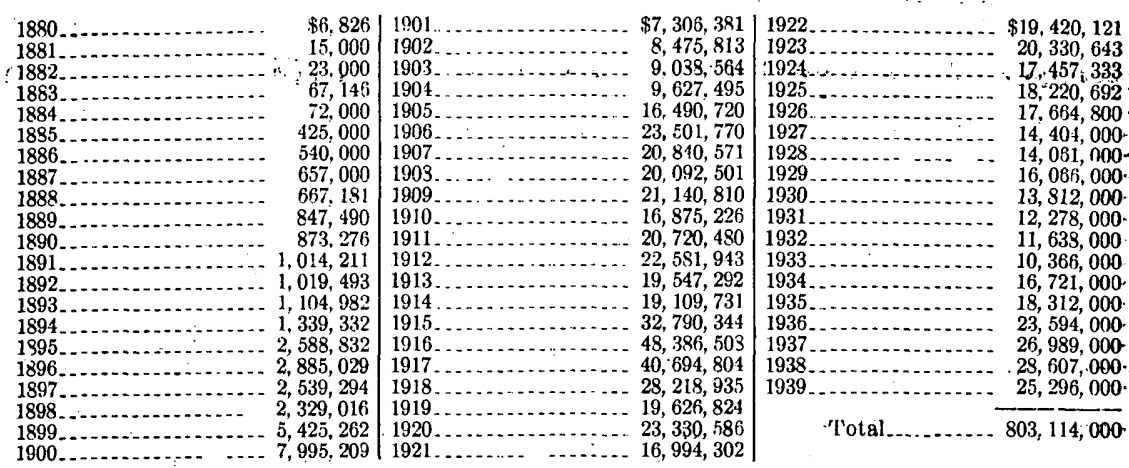

$\therefore$ Nore $-\$ 37,305$ for coal produced prior to 1890 has been; credited to 1890 , as :data are not:ayailable for distributing the value by years.

In the table on page 12 the value of the total mineral production from. Alaska is distributed among the various metals and nonmetallic products. From the table it will be seen that gold accounted for more than 66 percent of the total value of the mineral production and that gold and copper together accounted for more than 95 percent. 


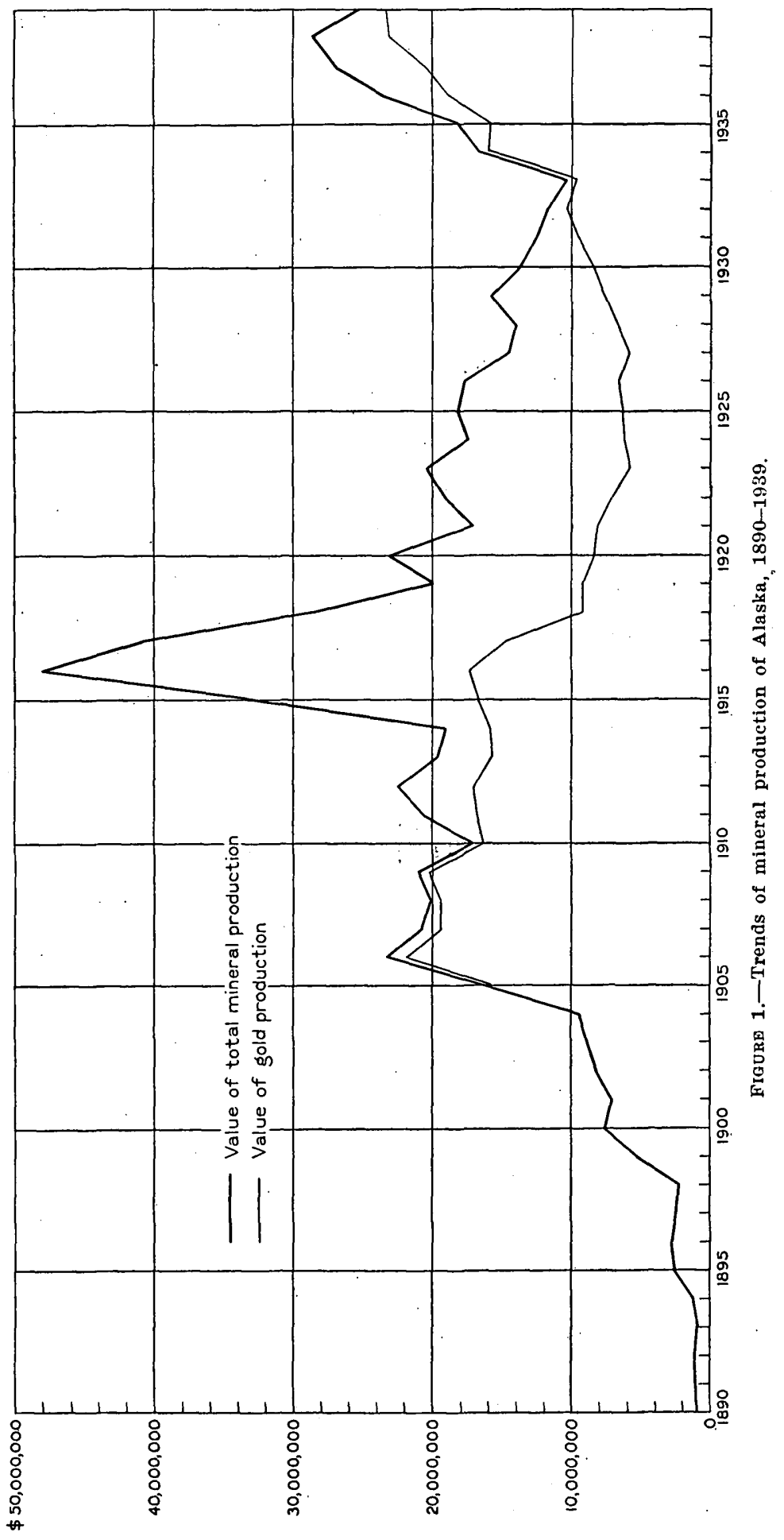


Total value of mineral production of Alaska, by substances, 1880-1939

Gold $\$ 535,936,003$

Copper $227,408,400$

Silver

$13,622,000$

Coal $12,209,460$

Lead.

$2,588,600$

Tin $1,583,800$

Other mineral products (including platinum miıerals)

9,$765 ; 800$

Total

$\Rightarrow$

Each mineral product is discussed in more detail in the following pages, in which are set down such facts as are available regarding the amount of each product, the places from which it came, and any new developments. The following summary table shows the production for 1939 and 1938, distributed by quantity and value among the main kinds of substances, so that a comparison between the 2 years may be readily made. From this table it is apparent that there was an increase in the quantity and value of gold and miscellaneous mineral products and a slight increase in the value of the lead produced in 1939 but a decrease in both the quantity and value of the output of copper, silver, platinum metals, tin, and coal in 1939.

Mineral output of Alaska, 1939 and 1938

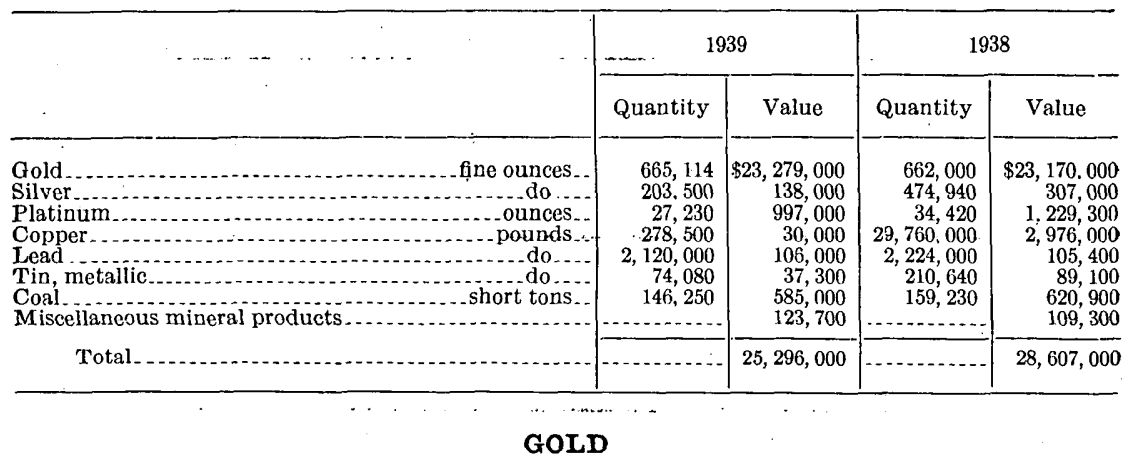

GENERAL FEATURES

Throughout 1939 the price of gold remained fixed officially at $\$ 35$ an ounce, the same as it has been since 1933. It should be borne in mind, however, in all comparisons made with the records of the earlier years that the value of gold produced prior to 1934 has been computed on the then prevailing price of approximately $\$ 20.67$ an ounce, or only about 60 percent of the present price. The value of the gold production of Alaska in 1939. was $\$ 23,279,000$, as against $\$ 23,170,000$ in 1938 , an increase of $\$ 109,000$. This marks an all-time high record, the near- 
est approach to it prior to 1938 being in 1906 when the value of the gold production was $\$ 22,036,794$. Although in value the gold produced in 1939 exceeded that of any other year, in quantity the production did not come up to that of any of the years between 1905 and 1917, when the price of gold was lower.

Gold produced in Alaska, 1880-1939

\begin{tabular}{|c|c|c|c|c|}
\hline \multirow{2}{*}{ Year } & \multirow{2}{*}{ Fine ounces } & \multicolumn{3}{|c|}{ Value } \\
\hline & & Total & Placer mines & Lode mines \\
\hline $\begin{array}{l}1880-19 \\
1900\end{array}$ & $\begin{array}{r}1,153,889 \\
381,921 \\
348,300 \\
403,206 \\
423,185 \\
440,938 \\
766,550 \\
1,066,030 \\
936,043 \\
933,290 \\
987,417 \\
780,131 \\
815,276 \\
829,436 \\
755,947 \\
762,596 \\
807,966 \\
834,068 \\
709,049 \\
458,641 \\
455,984 \\
404,683 \\
390,558 \\
359,057 \\
289,539 \\
304,072 \\
307,679 \\
324,450 \\
286,720 \\
331,140 \\
375,438 \\
410,020 \\
459,900 \\
493,860 \\
469,286 \\
457,343 \\
445,429 \\
526,660 \\
582,085 \\
662,000 \\
665,114 \\
4\end{array}$ & $\begin{array}{r}\$ 23,853,000 \\
7,895,000 \\
7,200,000 \\
8,335,000 \\
8,748,000 \\
9,115,000 \\
15,846,000 \\
22,036,794 \\
19,349,743 \\
19,292,818 \\
20,411,716 \\
16,126,749 \\
16,853,256 \\
17,145,951 \\
15,626,813 \\
15,764,259 \\
16,702,144 \\
17,241,713 \\
14,657,353 \\
9,480,952 \\
9,426,029 \\
8,365,560 \\
8,073,540 \\
7,422,235 \\
5,985,314 \\
6,285,724 \\
6,360,281 \\
6,707,000 \\
5,927,000 \\
6,845,000 \\
7,761,000 \\
8,476,000 \\
9,507,000 \\
10,209,000 \\
9,701,000 \\
16,007,000 \\
15,940,000 \\
18,433,000 \\
20,373,000 \\
23,170,000 \\
23,279,000\end{array}$ & $\begin{array}{r}\$ 8,692,000 \\
5,623,000 \\
4,980,000 \\
5,887,000 \\
6,010,090 \\
6,025,000 \\
12,340,000 \\
18,607,000 \\
16,491,000 \\
15,888,000 \\
16,252,638 \\
11,984,806 \\
12,540,000 \\
11,990,000 \\
10,680,000 \\
10,730,000 \\
10,480,000 \\
11,140,000 \\
9,810,000 \\
5,900,000 \\
4,970,000 \\
3,873,000 \\
4,226,000 \\
4,395,000 \\
3,608,500 \\
3,564,000 \\
3,223,000 \\
3,769,000 \\
2,982,000 \\
3,347,000 \\
4,117,000 \\
4,837,000 \\
4,842,000 \\
5,522,000 \\
5,152,000 \\
8,955,000 \\
9,703,000 \\
11,328,000 \\
12,655,000 \\
14,897,000 \\
16,058,000\end{array}$ & $\begin{array}{r}\$ 15,161,000 \\
2,272,000 \\
2,220,000 \\
2,448,000 \\
2,738,000 \\
3,090,000 \\
3,506,000 \\
3,429.794 \\
2,858,743 \\
3,404,818 \\
4,159,078 \\
4,141,943 \\
4,313,256 \\
5,155.951 \\
4,946,813 \\
5,034,259 \\
6,222,144 \\
6,101,713 \\
4,847,353 \\
3,580,952 \\
4,456,029 \\
4,492,560 \\
3,847,540 \\
3,027,235 \\
2,376,814 \\
2,721,724 \\
3,137,281 \\
2,938,000 \\
2,945,000 \\
3,498,000 \\
3,644,000 \\
3,639,000 \\
4,665,000 \\
4,687,000 \\
4,549,000 \\
7,052,000 \\
6,237,000 \\
7,105,000 \\
7,718,000 \\
8,273,000 \\
7,221,000\end{array}$ \\
\hline Total. & $23,594,896$ & $535,936,000$ & $348,074,000$ & $187,862,000$ \\
\hline
\end{tabular}

The general trend of gold mining in Alaska since 1880 is graphically represented by one of the curves in figure 2. From 1880 to 1884 only negligible amounts of gold were produced. Then the curve of production gradually steepened, until in 1895 the former production nearly doubled, and this remained fairly constant until 1900, when the great increase marking the discovery of the rich deposits near Nome carried the value of the annual output of gold to about $\$ 8,000,000$, near which it remained until 1904 . From 1880 to 1904 the curve of gold produced practically coincides with the curve for the value of the total mineral production of Alaska. From 


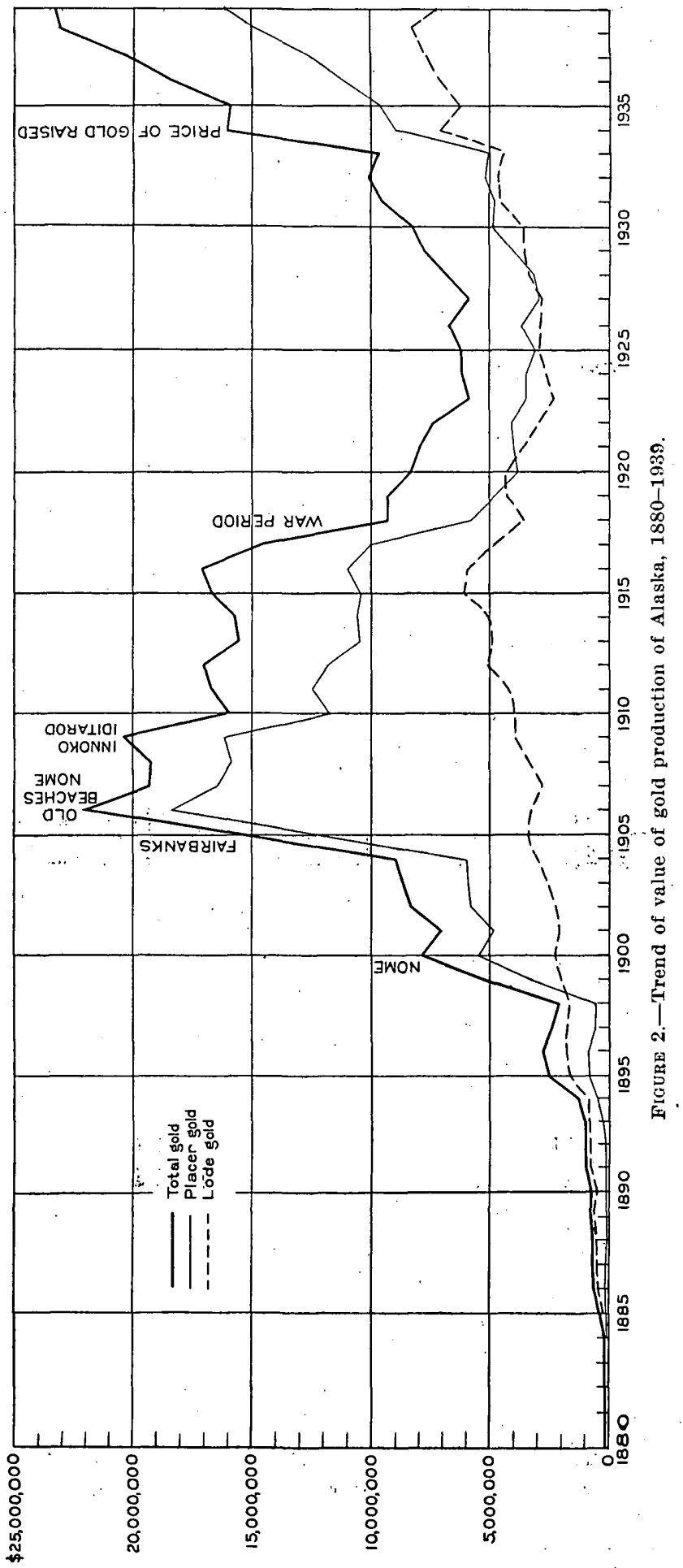

2 
1.904 to 1906 there was an abrupt increase in gold production, marking the boom periods of many of the placer camps. From the peak of 1906 there was a gradual decline for the next 10 years, and during the period of the World War there followed a rather rapid decrease to less than $\$ 10,000,000$ a year. During the post-war period from 1920 to 1927 there was a still further decline in Alaska gold production, and it touched new lows in 1923 and 1927, when it was less than $\$ 6,000,000$ a year. Since 1927 there has been in general a marked increase in the value and quantity of gold produced, until in 1934 the rise in the unit price of gold, coupled with the stimulation of gold mining that had been in progress, so increased the value of the production that in 1939 it exceeded that of the boom days of gold production in the Territory.

There are two principal types of deposits from which the gold is recovered-lodes and placers. The lodes are the mineralized veins cr masses of ore in the country rock that were in general formed through deep-seated geologic processes and represent material in place. The placers are deposits of sand and gravel which have been worn from the hard rocks in their general vicinity and in which the loose grains of gold or other valuable minerals have been more or less concentrated by surficial geologic processes that were effective because of some distinctive physical or chemical property of the material thus concentrated.

The table on page 13 shows the amount and value of the gold: produced annually for the last:40 years, the total amount that thas been produced since gold mining began in the Territory in 1880, and the value of the gold that has been derived from each of the two principal types of gold mines. The annual production for each year from 1880 and the sources, from 1884, are also shown graphically in figure 2. Of the $\$ 535,936,000$ in gold that has been produced from Alaska mines $\$ 348,074,000$ or about 65 percent, has come from placers and $\$ 187,862$,1000 or about 35 percent, from lodes. In the past the relation between the outputs from these two sources has: varied -widely. Thus up to 1898 the lode production was greater than that from the placers. Then 'ensued a period' of more than 20 years when the annual placer production far exceeded that from the lodes. From 1919 to 1933 the production was about evenly distributed between the two sources. Since then, with the growth in the mining of extensive low-tenor placer deposits by highly mechanized plants, the production of gold from the placers has exceeded that from the lodes, so that for a number of years the ratio of production from these two sources has been about 3 to 2 . There is reason to believe that the current rates of production are by no means rates that may not be maintained or exceeded in succeeding 
years. Although obviously the output of placer gold may be expected to lessen as time goes on, there is no evidence yet that such a point is near at hand, and increasing production from the lode mines may be predicted with all confidence.

\section{GOLD LODES}

Alaska lode mines in 1939 yielded $\$ 7,221,000$ in gold, or $\$ 1,052,000$ less than in 1938 , when the production was $\$ 8,273,000$. The gold derived from the lodes was about 31 percent of the entire gold production of the Territory, or somewhat less than the proportion in 1938. The lode gold was recovered from widely distributed mines, but approximately 70 percent came from mines in southeastern Alaska, as shown in the following table:

Gold produced from gold-lode mines in Alaska in 1999, by districts

\begin{tabular}{|c|c|c|}
\hline & $\begin{array}{c}\text { Fine } \\
\text { ounces }\end{array}$ & Value \\
\hline 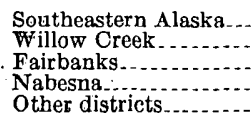 & $\begin{array}{r}145,628 \\
38,229 \\
15,714 \\
2,543 \\
4,200\end{array}$ & $\begin{array}{r}\$ 5,097,000 \\
1,338,000 \\
550,000 \\
89,000 \\
147,000\end{array}$ \\
\hline Total & 206,314 & $7,221,000$ \\
\hline
\end{tabular}

Of the Alaska lode-gold mines, the properties of the Alaska Juneau Gold Mining Co. in southeastern Alaska are by far the largest, and that company alone produced about five-eighths of the total lode-gold output of the Territory in 1939. The magnitude of the company's mining operations is set forth in its published report to its stockholders, ${ }^{4}$ from which the following statements are abstracted: The total rock mined and trammed to the mill in 1939 was 4,648,060 tons. Of this amount $2,270,342$ tons of coarse tailings were rejected, and $2,377,718$ tons were fine-milled. The average gold content of all the material mined during 1938 was 0.0352 ounce to the ton. The amount of gold in that part of the rock that was rejected was about 0.0066 ounce to the ton, and the gold content of the rock that was further treated was about 0.0625 ounce to the ton. Of this content 0.0083 ounce to the ton was lost during the treatment, 0.0454 ounce was recovered as bullion, and 0.0088 ounce was recovered in the concentrates, which were subsequently smelted. The following table, compiled from the published reports of the Alaska Junean Gold Mining Co., summarizes the mining record of this company since the beginning of its operations in 1893.

\footnotetext{
4 Alaska Juneau Gold Mining Co., 25th Ann. Rept., for the year ended December 31, 1939.
} 
Production of Alaska Juneau mine, 189s-19s9

\begin{tabular}{|c|c|c|c|c|c|c|c|}
\hline \multirow[b]{2}{*}{ Year } & \multicolumn{3}{|c|}{ Ore (tons) } & \multicolumn{4}{|c|}{ Metals recovered } \\
\hline & Total & $\begin{array}{l}\text { Fine } \\
\text { milled }\end{array}$ & $\begin{array}{l}\text { Coarse } \\
\text { tailings } \\
\text { rejected }\end{array}$ & $\begin{array}{l}\text { Gold } \\
\text { (ounces) }\end{array}$ & $\begin{array}{c}\text { Silver } \\
\text { (ounces) }\end{array}$ & $\begin{array}{l}\text { Lead } \\
\text { (pounds) }\end{array}$ & $\begin{array}{c}\text { Total } \\
\text { value } 1\end{array}$ \\
\hline $\begin{array}{l}1893-1913 \\
1914-15 \\
1916 \\
1917 \\
1918 \\
1919 \\
1920 \\
1921 \\
1922 \\
1923 \\
1924 \\
1925 \\
1926 \\
1927 \\
1928 \\
1930 \\
1931 \\
1932 \\
1933 \\
1934 \\
1935 \\
1936 \\
1937 \\
1938\end{array}$ & $\begin{array}{r}507,254 \\
242,328 \\
180,113 \\
677,410 \\
592,218 \\
692,895 \\
942,870 \\
1,613,600 \\
2,310,550 \\
2,476,240 \\
3,068,190 \\
3,481,780 \\
3,829,700 \\
4,267,810 \\
3,718,140 \\
3,836,440 \\
3,924,460 \\
4,162,350 \\
4,001,630 \\
4,085,960 \\
4,302,600 \\
3,729,660 \\
4,366,800 \\
4,442,760 \\
4,663,880 \\
4,648,060\end{array}$ & $\begin{array}{r}330,278 \\
239,918 \\
180,113 \\
677,410 \\
574,285 \\
616,302 \\
637,321 \\
904,323 \\
1,108,559 \\
1,134,759 \\
1,367,528 \\
1,537,884 \\
1,649,678 \\
1,839,695 \\
1,795,191 \\
2,020,470 \\
2,066,239 \\
2,298,998 \\
2,414,469 \\
2,466,832 \\
2,387,138 \\
2,091,475 \\
2,462,046 \\
2,251,079 \\
2,478,928 \\
2,377,718\end{array}$ & \begin{tabular}{r}
176,976 \\
2,410 \\
\hdashline 17,933 \\
76,593 \\
305,549 \\
709,277 \\
$1,201,991$ \\
$1,341,481$ \\
$1,700,662$ \\
$1,943,896$ \\
$2,180,022$ \\
$2,428,115$ \\
$1,922,949$ \\
$1,815,970$ \\
$1,858,221$ \\
$1,863,352$ \\
$1,587,161$ \\
$1,619,128$ \\
$1,915,462$ \\
$1,638,185$ \\
$1,904,754$ \\
$2,191,681$ \\
$2,184,952$ \\
$2,270,342$
\end{tabular} & $\begin{array}{r}34,240 \\
12,175 \\
5,565 \\
20,767 \\
20,809 \\
24,141 \\
35,456 \\
46,914 \\
62,707 \\
69,047 \\
92,277 \\
98,213 \\
93,423 \\
112,653 \\
152,047 \\
164,993 \\
163,312 \\
179,532 \\
151,578 \\
150,967 \\
128,015 \\
118,998 \\
149,235 \\
151,671 \\
148,103 \\
129,012\end{array}$ & $\begin{array}{r}(2) \\
6,192 \\
2,844 \\
12,248 \\
11,828 \\
16,431 \\
23,348 \\
40,619 \\
49,405 \\
41,876 \\
63,191 \\
55,971 \\
52,333 \\
61,232 \\
77,591 \\
90,635 \\
-97,607 \\
118,508 \\
94,519 \\
109,483 \\
86,458 \\
77,787 \\
101,591 \\
120,691 \\
121,473 \\
111,494\end{array}$ & $\begin{array}{r}(2) \\
117,031 \\
61,068 \\
296,179 \\
273,297 \\
359,762 \\
487,574 \\
550,913 \\
687,315 \\
755,423 \\
1,256,857 \\
1,288,974 \\
1,300,915 \\
1,513,306 \\
2,038,655 \\
2,501,832 \\
2,640,771 \\
3,309,176 \\
2,509,263 \\
2,299,777 \\
1,662,894 \\
1,455,167 \\
2,102,594 \\
1,980,405 \\
2,152,714 \\
2,040,280\end{array}$ & $\begin{array}{r}\$ 707,730 \\
261,326 \\
121,379 \\
460,666 \\
459,445 \\
542,714 \\
781,390 \\
1,035,251 \\
1,388,679 \\
1,514,774 \\
2,055,782 \\
2,184,384 \\
2,067,837 \\
2,463,262 \\
3,316,019 \\
3,627,247 \\
3,551,950 \\
3,879,839 \\
3,236,183 \\
3,960,166 \\
4,582,559 \\
4,281,110 \\
5,400,621 \\
5,516,414 \\
5,364,488 \\
4,695,537\end{array}$ \\
\hline Total & $74,765,698$ & $39,908,636$ & $34,857,062$ & $2,515,850$ & $1,645,355$ & $35,642,142$ & $67,466,752$ \\
\hline
\end{tabular}

1 Based on company's valuation.

Lost in tailings.

The cost of mining in 1939, as stated by the company, was 37.8 cents for each ton of ore trammed to the mill, the cost of milling was 24.4 cents, and all other marketing costs and expenses amounted to 11.4 cents, making the entire operating cost for each ton of ore trammed only 73.6 cents. This indicates the exceedingly efficient. operation in handling a deposit of this low-grade type, which could have been brought about only through capable management and the adoption of every technical means for maintaining and stimulating production in all stages of the enterprise.

The output of gold from this company's property in 1939 was nearly $\$ 670,000$ less than in 1938 , owing mainly to the somewhat lower tenor of the ore mined. Operating costs were maintained at essentially the same figure during the 2 years, so the lower production was reflected almost directly in operating profit. No interruptions due to labor conditions occurred during the year; in fact the superintendent reported that at all times there was an abundance of unskilled labor, though the supply of skilled workers was limited. Readjustments upward of general wage rates were made during the year. The superintendent reported that during 1939 more than 40,000 linear feet of underground openings were made, and more than 58,400 square feet of stope area was cut out. 'The development and preparatory work 
in opening up the extension of the property in the old Perseverance ground was continued with such good effect that during 1939 about 44 percent of the ore milled by the company came from this part of the property. In the mill experimental work demonstrated that further recovery of values from the coarser tailings was not practicable. without regrinding. Additional tube mills were therefore installed, and the mill is now equipped so that about half the ore milled will betreated by flotation, either as slimes or reground tailings.

At several places in the northern part of southeastern Alaska, which: for convenience may here be considered extensions of the Juneau district, some lode mining and prospecting was in progress in 1939 . The greatest amount of lode gold from these more remote parts of the district came from the property of the Alaska Empire Gold MiningCo., which is situated a short distance north of Hawk Inlet, Admiralty Island, and is some 20 miles southwest of Juneau. It has long been. productive on a small scale, and reports are common that attempts arebeing made to increase materially the scope of the operations. So faras reported to the Geological Survey, no productive lode mining was: in progress on the property of the Admiralty-Alaska Gold Mining Co. on Funter Bay, Admiralty Island, a few miles farther north.

The second most productive lode-gold district in southeastern Alaska: is situated on the west coast of Chichagof Island, some 75 miles southwest of Juneau. In this district the two principal mines are the properties of the Hirst-Chichagof Mining Co., at the head of Kimshan Cove, some 65 miles northwest of Sitka, and the Chichagoff Mining Co., near Klag Bay, a few miles to the southeast. These mines have long been large and consistent producers and appear capable of maintaining that record for many years more. At the Hirst-Chichagof, developinent and undérground work is being carried on at an especially active rate and with marked success. At the Chichagoff mine there has recently been a reorganization and change in management during which underground development has been slowed down and the production has come mainly from rehandling and treatment of tailings. produced in earlier years. The mineralization at these mines, as well as the geologic and structural features shown at other places throughout the district, encourages expectation that extension of the known ore bodies or the finding of new ones is to be sought with considerable assurance of success. The Geological Survey consequently has been making a rather intensive study of the district during the field seasons: of 1938 and 1939 under the direction of $J$. C. Reed. A report ${ }^{\circ}$ is now in course of publication setting forth the results of this work, which includes descriptions of all the mines and prospects in the district, with

\footnotetext{
- Reed, J. C., and Coats, R. R., Geology and ore deposits of the Chichagof mining district,
} Alaska: U. S. Geol. Survey Bull. 929 (in preparation). 
interpretations of the facts of geologic significance that they disclose and suggestions that should be helpful to prospectors and miners in this district. It is said that the results of this work have enabled some of the operators to plan and carry out developments that have led to the discovery of valuable ore shoots.

In addition to the two larger mines in the Chichagof district, there were more than a score of smaller mines and prospects on which some work was in progress. The largest prduction from any of these other properties came from the Apex-El Nido Mining Co., near the northern tip of Chichagof Island not far inland from Lisianski Inlet. At this mine a crew of a dozen men were engaged during most of the open season. The principal new installation at this place in 1939 was the addition to the milling equipment of three Denver flotation machines. Work was discontinued in September but, according to present plans, will be resumed as early in 1940 as is practicable.

The Ketchikan district of southeastern. Alaska, as the term is here used, embraces the entire southern and western part of the region. In the past it has contained scores of lode-mining properties that in the aggregate have yielded gold to the value of more than a million and a quarter dollars. At the present time the most active mining in the district is being done in three principal areas, namely, near the east coast of Prince of Wales Island, some 40 miles or so west of Ketchikan; near Helm Bay, Cleveland Peninsula, some 25 miles north of Ketchikan; and a lesser amount on Revillagigedo Island, some 16 to 18 miles east of Ketchikan.

According to the reports received by the Geological Survey, the largest production from the area on Prince of Wales Island came from properties of the Alaska Gold \& Metals Co., of the Flagstaff Mining. Co., and of Wendall Dawson; all of which are near the western limit of Kasaan Bay or its southern extension, Twelvemile Arm, or from Nelson \& Tift mine, which is near McLean Arm, on the east coast of Prince of Wales, a few miles north of the southern tip of the island. The ore of the Salt Chuck mine of the Alaska Gold \& Metals Co. is a basic rock heavily impregnated with sulphides carrying some gold and considerable copper, which are recovered by smelting. The particularly unique feature of this ore is that, in addition to the gold and copper, it carries considerable quantities of palladium, one of the group of platinum metals. In fact this is practically the only known source of lode palladium in commercial quantities in the United. States. Further mention of this occurrence will be made under the subject, "Platinum metals," on page $7 \dot{5}$. At the Flagstafl mine, which is situated on Granite Mountain at the head of Karta Bay, some 20 men were "employed;" principally on surface construction, including road building. A new 25-ton mill was installed during the season and 
was put into operation in September. The use of the old mill of 10-ton capacity was continued even after the new mill was running. Work at the Dawson property, near Hollis, was carried on at about the same rate as during the immediately preceding years. The Nelson \& Tift mine is reported to have installed a new 28 -ton ball mill on its property during the year. The mine is said to be developed mainly by an adit approximately 1,100 feet long. Difficulties in treatment of the ore and delays incident to the installation of the new equipment and for road building prevented as large production as had been made in the preceding years. The valuable materials of the ore are recovered by amalgamation, tabling, and flotation.

In the area near Helm Bay, north of Ketchikan, only a few small properties are reported to have been active. Of these, the two principal producers were the old Gold Standard and the Blue Jay. The main item of news as to developments at the Blue Jay mine is that during 1939 a 25 -ton ball mill was installed with necessary accessories, such as classifier, plates, and concentrators. This seems to show clearly that the property will be opened up on an enlarged scale in the near future.

Still farther north of Ketchikan and actually in the Wrangell district, some development work is reported to have been done on the Maid of Mexico mine, on Kupreanof Island. Somewhat more than 1,000 feet of tunneling and other underground excavation has been done, and the showings are said to have encouraged the owners to such an extent that they propose to install a mill on the property in the near future.

In the area east of Ketchikan practically the only mining work that is known to have been in progress was on certain of the old properties adjacent to Thorne Arm. This work does not appear to have involved much new underground development but was directed toward obtaining additional financing and in rehabilitating one of the old mills.

In the Hyder district, which includes a considerable tract of country at the head of Portland Canal, in southeastern Alaska, no extensive lode development was in progress, and even the sudden increase of interest in prospecting that was earlier awakened by the great increase in the price of gold seems to have practically died out. So far as the Geological Survey is informed, only desultory prospecting was in progress at a few of the properties that a few years before had been active, and no significant amounts of ore or concentrates were shipped from any of them during 1939.

The Willow Creek district, at the head of Cook Inlet, has long been the second most productive lode-gold district in the Territory and has produced gold worth more than $\$ 10,370,000$ since lode mining started there in 1909 . Mining was in progress in 1939 at several camps 
scattered through the district, but the three largest producing mines were the Independence mine, of the Alaska-Pacific Consolidated Mining Co., near the head of Fishhook Creek; the Willow Creek mine, of the Conwest Exploration Co., on Craigie Creek; and the Fern mine, of the Fern Gold Leasing Co., near Archangel Creek. In addition, lode-gold production was reported from the Gold Cord, the Gold Bullion, and the Mabel mines, as well as from smaller properties where the season's work was little more than prospecting and the carrying on of preparatory examinations.

The Alaska-Pacific Consolidated Mining Co.'s property embraced the former holdings of several independent companies in the neighborhood, which were being brought into a unified plan of development as rapidly as conditions permitted. Thorough integration of all the operations has not yet been accomplished, but the completion of new, modern mills at central points to receive ore from most of the underground openings has done much to simplify and facilitate operations. These mills are equipped with 50-ton Marcy ball mills, and the values in the crushed ore are recovered by amalgamation and flotation. An old Lane Chilian mill of 25-ton capacity was also in service during most of the open season. Underground developments during the year at this property consisted in sinking the main shaft some 200 feet to the 1,100-foot level and turning off drifts about 500 feet long in both directions on that level, as well as driving many other crosscut stopes and drifts throughout the mine. The management estimates that altogether there are now some 8 miles of underground openings on the property.

At the Willow Creek mine the new management continued extensive underground developments and explorations. As a result of this work the faulted-off portion of its main vein was discovered to the west of the point at which it had been cut off and a new low levelthe so-called 725 foot level-partly opened up. The finding of ore at this greater depth should do much to dispel the belief formerly held by some that the ore in this part of the mine extended only to very shallow depths. The ore is treated in a 40-ton Marcy mill, much of the gold being recovered by amalgamation and the rest by cyaniding of the flotation concentrates. The tailings from the cyanide treatment are sent to a smelter in the States. Some of the tailings from the flotation treatment are retreated in the company's own leaching plant.

Work at the Fern mine was carried on during 1939 at an accelerated rate. The capacity of the mill was increased so that it is now rated as capable of handling about 30 tons of ore a day. During the year a tunnel about 2,000 feet long was driven to tap the vein at a considerable depth below the present workings and to afford a cheap 
means of transporting the ore from the mine to the mill. An automatic mechanical mucker was installed to facilitate handling the ore and waste, and the use of an electric locomotive speeds up tramming operations. The quality of the ore in the lower levels of the mine has continued to be as good as it was in the higher levels, so that the outlook for the mine appears to improve as developments progress.

The third most productive of the Alaska lode-gold districts that are listed separately in this report, was that in the vicinity of Fairbanks. In fact, the production of this district in 1939 was more than $\$ 120,000$ greater than in 1938 , which up to that time exceeded the production of any other of the 28 years that lode mining had been in progress in that camp.

There are two principal producing lode-gold areas more or less close to Fairbanks; one embraces the country adjacent to Pedro Dome and lies 15 to 20 miles north and east of the town, and the other embraces parts of Ester Dome and lies 6 to 10 miles west of the town. In the Pedro Dome area the larger producing mines lie outside the borders of the quartz diorite mass that forms the higher parts of Pedro Dome, in the old metamorphic schists that have been intruded by that mass and affected by it. The three largest producing mines in this area are those of the Cleary Hill Mines Co., the McCarty mine, and that of the $\mathrm{Hi} \mathrm{Yu}$ Mining Co., but at a dozen smaller properties in the same general area some mining or prospecting was actively in progress.

The McCarty property, which is situated near the divide at the head of Fairbanks Creek, was leased by the Fairbanks Department of the United States Smelting, Refining \& Mining Co. Exploration of the deposits and milling of the resulting ore were prosecuted vigorously throughout most of 1939 . During that time some 465 feet of drifts and crosscuts and nearly 400 feet of raises were driven. The ore was treated in a two-stamp Nissen mill with plates and crusher. The tailings were impounded for retreatment, should such a course prove desirable. No public announcement has been made by the company as to its intentions regarding continuation of the work at this place. The careful manner in which each step of the work was carried out should afford valuable records as to all phases of the occurrence of mineralization in this part of the district and as to the cost of getting the product into salable form.

At the Cleary Hills mines production was continued throughout 1939 at a somewhat higher rate than during the preceding year. Much of the company's activity, however, seems to have been directed toward exploration of its ground and solving some of the complex structural problems caused by the various faults that have dislocated the ore bodies: These studies seem to have cleared up some of the relation- 
-ships and to have disclosed some relatively accessible ore that had been missed in the earlier work. Much still remains to be done before a complete understanding of the ore bodies is attained, and in the meantime the operators are proceeding cautiously before -embarking on any extensive scheme of development that might sentail a heavy outlay.

The other principal mine in the eastern area of the Fairbanks rlistrict is the Hi $\mathrm{Yu}$ mine, on Too Much Gold Creek, a tributary of Fairbanks Creek. During 1939 some 15 to 18 men on the average were employed at this property on surface and underground improvements and operations. A number of difficult structural problems have faced the company in its search for the continuation of its ore bodies beyond the point where they are cut off by faulting. The lack of readily recognized markers, the small size of the vein, and the weakness of the wall rocks introduce difficulties in their quest that are hard to surmount. Progress was made, however, in the search for rore so that the mill could be kept running much of the time. The mill has two batteries of five stamps each. Much of the free gold is recovered in the mortars or on the plates of these batteries, but some of it, as well as that contained in the sulphides, is saved in the flotation units. The concentrates from the flotation cells are shipped to smelters in the States.

In the Ester Dome area of the Fairbanks district the development of gold lodes continued at essentially the same places but rather less vigorously than heretofore. The great activity that took place in 1938 at the old Ryan lode, near the head of St. Patrick Creek, was suspended during most of 1939 . Cessation of the work at this property is believed to be only temporary, and there is every indication that in 1940 it will be prosecuted even more vigorously than heretofore. In fact, before the close of 1939 a small crew of men was reported to have resumed underground work at the mine, and the construction of additional buildings for the surface plant was said to be in progress. Other properties in the Ester Dome area that reported some lode gold production in 1939 were those of the Mohawk Mining Co. and Pete Nickoloff on the northern slopes of the Dome. In addition there were half a dozen or more smaller mines and prospects widely scattered at various places on Ester Dome that individually yielded but a small amount of lode gold in 1939 but collectively contributed considerable gold to swell the total of the district.

The fourth most productive Alaska lode-gold district is that in the valley of the Nabesna River. In this district, at the present time, there is only one producing mine, that of the Nabesna Mining Corporation. The Survey under its regular practice would not be permitted to disclose the production of a single mine, but, as this company 
itself publishes for its stockholders a complete analysis of its operations, that restriction is removed. The following statements are, therefore, abstracted from the quarterly reports of the company. The noteworthy event of the year at this property was the very great falling off in production as compared with 1938. Many factors interacted to bring about this situation. Part may be attributed to the handicaps caused by the fire early in January which destroyed the compressor plant. More serious, however, was the failure to develop sufficient reserves of ore. As a result of these and other causes the company is reported to have mined and sent to the mill about 5,000 tons of ore, to have made some 1,630 lineal feet of underground openings, and to have bored 3,364 feet of diamond drill hole.

Among the lode-gold districts that are grouped together in the table on page 16 under the heading "Other districts," the most productive, named in the order of output, are the vicinity of the Kantishna district, on the northern slopes of the Alaska Range; Kenai Peninsula, including the Nuka Bay: area, the area south of Hope, and the hills north of Girdwood; the Nixon Fork district, in the Kuskokwim region; the vicinity of Valdez and other parts of the Prince William Sound region; and a few districts widely scattered through other parts of central and western Alaska, the gross output of which totaled only a few thousand dollars in gold. In practically every one of these districts the production in 1939 came from a single mine, so that to avoid disclosing the individual output it has been necessary to combine the statistics.

The producing lode mine in the Kantishna district is that of the Red Top Mining Co., whose active work was in progress on the Banjo claim, near the head of Lucky Gulch, a small tributary to Eureka Creek from the north. A new management had taken over the property late in 1938, so that much of 1939 was spent in building adequate surface facilities and in making other preparations for opening the mine. Some of this work was much hampered by an exceptionally early and heavy snowfall in August, which tied up transportation temporarily and necessitated diversion of personnel from production work to break the blocked roads. In spile of these difficulties and those that are always incident to opening up a new mining property, the operators considered the progress satisfactory and the results fully up to their expectation.

The principal districts in the Kenai Peninsula district in which some lode-gold production was reported in 1939 were Nuka Bay, Moose Pass-Hope, and Girdwood. The Nuka Bay district embraces. country near the extreme southern part of Kenai Peninsula; the Moose Pass-Hope district embraces much of the country lying north of the Moose Pass station, on the Alaska Railroad, and extending to. 
the old settlements of Hope and Sunrise, on Turnagain Arm; the Girdwood district lies just north of Kenai Peninsula, extending a few miles northward from the shores of Turnagain Arm. The entire belt of rocks in which the deposits of these three districts occur, and which extends even over into parts of the Valdez district, is dominantly a deformed series of slate and graywacke, which has been intruded locally by igneous dikes that are currently referred to as "greenstones." The veins occupy fractures of rather irregular form and moderate extent, and their gold content is largely free gold, though sulphides are by no means uncommon. Little information is available on new lode-gold developments in any of these districts in the Kenai region, and it seems likely that no new developments of other than local significance occurred in any of them. In all the areas the mines are small, only a few men being employed in each, and most of the equipment is of a simple type.

In the Nuka Bay district there are perhaps half a dozen properties on which some work was done during the year, but at only three of them was the work much more than casual prospecting. These three were the Nukalaska Mining Co., the Alaska Hills Mining Co., and the Sonny Fox Mining Co. Heavy snow slides during the winter of 1938-39 damaged some of the surface equipment at the Nukalaska property, but in spite of the delays required for these repairs the operators were able to extend the long crosscut they had.been driving about 350 feet.

Farther north on Kenai Peninsula, in the Moose Pass-Hope disirict, and, in fact, at intervals all the way between Seward and Moose Pass are small gold-lode properties at which more or less prospecting is kept up and from some of which small amounts of lode gold are obtained each year. Most of the operators of these properties fail to supply much information on their season's work, possibly feeling that it is too small to be of other than personal interest. This feeling is not warranted, because it is significant that mineralization has been proved to be widespread throughout much of this area, and it is desirable to have a full record of the results of any work that has been done in order to discover workable deposits there and to open them up. So far as the Geological Survey is informed the properties in the district at which most active work was done during 1939 were the old Gilpatrick and Oracle mines, near the divide between Quarti and Canyon Creeks, and the New Hope, Nearhouse, and Hirshey properties, near Palmer Creek.

In the Girdwood district, north of Turnagain Arm, the principal area in which some development of gold lodes was in progress in 1939 was near the head of Crow Creek, a tributary of Glacier Creek. The only mine in this camp is the Monarch-Jewel mine, of the Crow Creek 
Gold Corporation, under the management of H. I. Staser. No firsthand information has been received by the Geological Survey as tothe year's progress at this property, but it is currently reported that. work was carried on at about the same rate as during the immediately preceding years.

In the Kuskokwim Valley the only producing lode-mining area is: in the vicinity of Nixon Fork, north of Berry Landing. The principal producing mines in this area are the Nixon Fork mine, operated by Mespelt \& Co., and the Southern Cross mine, of McGowan. \&Lind. Work at the Nixon Fork mine was continued throughout the year at about the same rate as heretofore, but the value of the output of gold recovered seems to have been somewhat more than in 1938 . Only a small crew is engaged on the property, and the general practice has been to do most of the underground work during the winter and get a sufficient stock of ore on hand to supply the mill during the open season. Then when water for milling becomes available the underground work is suspended, and the men are mainly busy in the mill or in preparing for the next winter's work. The mill is equipped with 10 gravity stamps, but its capacity is limited by the small supply of water that is available in a normal season. The Southern Cross mine is about a mile from the Mespelt property, in the same general geologic setting with relation to the contact of the quartz monzonite intrusive and the limestone country rock. Only a small amount of ore was producêd from this property during the year, and none: was milled.

Few details regarding the lode-gold mining in progress in the Prince William Sound region in 1939 have been received by the Geological Survey direct from the operators there. From general sources it is apparent that the lode-gold production of the district was very much less than it has been in recent years. The principal mine in the district is the old Cliff mine, a short distance west of Valdez. Here much of the season of 1939 was spent in development work, which consisted largely in the unwatering of the mine to the 500 -foot level. The 'mill was in operation for only part of the season. 'At the Portage Bay Mining Co.'s property most of the surface plant was destroyed by snow slides, so that much of the open season was spent in repairing the damage, and less than a month was spent in productive mining. No productive mining is reported to have been in progress at the Ramsey-Rutherford, Mayfield, Culross, Granite, or Bettles Bay mines, which at times in the past have yielded considerable amounts of lode gold. At Pigot Bay a camp employing four or five men was maintained by C. W. Poy; but, so far as the Geological Survey:is informed, it did not prodüce any lode gold, and late in the season Mr. Poy left to resume the work at the Big Four 
mine, on Mineral Creek near Valdez, a property that he has been developing for a number of years.

In the Copper River region the only lode-gold mining in progress was that done by the Yellow Band Gold Mining Co., Inc., on its properties in the Bremner district. The property is in a developmental stage, so that much of the year was spent in the construction of the surface plant and its equipment. The major item of this construction was the building of a 4,800 -foot aerial tram and about $41 / 2$ miles of truck road from the end of the tram to the mill. Development work was continued in the opening up of the ore showings, and in the course of that work sufficient ore was taken out to keep the mill in operation intermittently for a period of about 2 months. The mine is equipped with a 50-ton Marcy ball mill and amalgamation plates and a concentration table. The concentrates from the table are fed back into the ball mill for regrinding.

In the Chulitna district, on the southern slopes of the Alaska Range near Broad Pass, an extensive gold-lode development was in progress under the direction of W. E. Dunkle. This property, known as the Golden Zone, or formerly as the Wells Bros. prospect, is situated on the West Fork of the Chulitna River some 10 miles west of the Colorado station on The Alaska Railroad. Work at this place has consisted mainly in constructing the necessary surface plant and equipment required for mining and milling an average of 100 tôns of ore a day." The ore is a cổmplex mixture of sulphides carrying some copper, silver, and lead in addition to gold, which is the principal valuable constituent. In mid-September, when the property was visited by the writer, the foundation of the mill was being poured, clearing for the foundation of the new power plant was well under way, and most of the other camp buildings, both at the base camp near the river and at the upper site near the mine, had been completed. It was evident that practically all of this preparatory work would be finished before the end of the year, so that the present plant would be in full operation early in 1940. It is understood that the present plant was designed to serve more or less as an experimental unit before attempting the full development that the property is believed to warrant.

Prospecting for gold lodes was continued at many other places throughout the Territory, though at none of them, so far as reported to the Geological Survey, was any ore mined or any gold produced except the little that may have been recovered in the course of testing the ore during development work. Among places of this sort the more significant were the Goodpaster district of the Yukon-Tanana region and a few widely scattered points in Seward Peninsula. 
In the Goodpaster district a crew of five to seven men was employed in prospecting and development work on veins that have been found in the vicinity of Tibbs Creek. It is understood that an extensive campaign of drilling will be undertaken to test the are: and the work will be continued throughout the winter of 1939-40 if such a course proves desirable. In Seward Peninsula some lode-gold mining was done at two or three places near the head of Snake River, some 20 miles north of Nome. Prospecting was continued on a small scale at Silver's prospect, near Solomon. More extensive developments were reported to have been started in the vicinity of Bluff, some 50 miles east of Nome, with a view to opening up some of the gold-lode deposits that have long been known to occur in that area. This project involves determination of a number of complex geologic features, as well as of ore-dressing practices, so that it will doubtless take considerable work before the operators can acquaint themselves adequately with the facts necessary for undertaking a well-planned program of development. It is also reported that some steps were taken looking to the reopening of the old Apollo and Sitka mines, on Unga Island, off the coast of the Alaska peninsula.

\section{GOLD PLACERS}

\section{GENERAL CONDITIONS}

Placer mining in Alaska in 1939 yielded gold worth $\$ 16,058,000$. This amount marks an increase in value of more than $\$ 1,160,000$ and in quantity of nearly 33,200 ounces over the output of the preceding year. In fact, the value of the placer production was greater than for any other year since 1909 and has been exceeded in only 3 years in the entire time that placer mining has been in progress in the Territory. In 2 of those years the excess was only $\$ 433,000$ and $\$ 194,000$, and in the third it was approximately $\$ 2,550,000$.

The annual production of placer gold and certain other data relating to Alaska's gold production are represented graphically in figure 2 (p. 14). From this diagram may be traced many of the changes that have taken place in the industry. Thus, in no year from the begimning of the industry in 1880 to 1899 did the production of placer gold amount to as much as $\$ 1,000,000$, and the average during that period was less than $\$ 280,000$. In 1899 there was a sudden increase, marking the discoveries of Nome and some of the camps in the upper Yukon Valley, which were soon followed by the discovery of Fairbanks and many of the other camps of the interior. The resulting golden period lasted through 1916, during which the annual yield of placer gold averaged more than $\$ 10,000,000$ and in 1906 reached the peak of approximately $\$ 18,600,000$. In 1918 , after the entry of the' United States into the World War, placer production dropped to about $\$ 6,000,000$, 
and in the 15 years from that time to 1933 it fluctuated between that amount and $\$ 3,000,000$. Since 1934, owing in part to the great increase in the price of gold and in part to the revived interest in placer mining, the value of the output has rapidly climbed each year until in 1939 it reached the high figure stated above.

The trend of placer mining in Alaska for the last few years has been toward the development of larger enterprises requiring the installation of expensive equipment, such as dredges, draglines, or other mechanical devices, and the mining of relatively low-grade deposits through careful control of costs. Such enterprises are not undertaken casually, nor can they be nmade productive the stimulation brought about by the increased price of gold there must necessarily be a considerable lag before the larger new enterprises become noteworthy producers. Small operations, which do not require such elaborate preparations, show less lag in attaining production. As a consequence, while many small placer-gold operations sprang up almost at once after the announcement of the: rise in the price of gold, only recently have any large undertakings that resulted from the stimulation become productive, and some of the larger ones have not yet come into full production. Conversieliy; when adverse factors arise they usually result first in shutting down: the small operators, who can more readily curtail work at their properties because the unavoidable charges on their investment are less. It is too soon, therefore, to gage accurately the results that some of the recent. acts relating to taxation, social security, and other matters will have on the placer-mining industry of the Territory, but already some of the small operators have reported that they found the additional expenses so burdensome that they were curtailing their activities. Obviously, before new enterprises are undertaken these additional items of expense will have to be figured in any estimates of the probable returns from the projects.

The stimulus of the high price of gold and unemployment in many businesses in the States have led many to think about turning to prospecting in Alaska as a means of improving their condition: To such it may not be amiss to offer the following comments. The life of the prospector has much that is attractive to a man who enjoys the simple life, working more or less as his own boss, when, where, and how he pleases, and with the allurement of possibly discovering a real prize as a result of his efforts. Such a career obviously should be undertaken only by the physically fit and those reasonably skilled in understanding Nature's secrets and the ways of acquiring what she has to offer. Prospecting is just as much a specialized business as farming or storekeeping, and outstanding success comes to few in 
any line of endeavor. Inevitably the life of the prospector is full of physical hardships and should not lightly be undertaken by the ordinary city dweller. It is believed, however, that Alaska still holds opportunities for the capable placer prospector to find tracts that, while not bonanzas, will well repay his best endeavors. It is still true that there are large tracts of Alaska that have not yet been thoroughly prospected or adequately examined, but it should not bs forgotten that all the readily accessible parts of Alaska have been at least traversed by prospectors and hunters in the past, so that the newcomer, unless he possesses keener insight or some other qualities that these earlier searchers lacked, is not likely to have his quest for fortune rewarded by stumbling on rich deposits they missed. None of the open unworked areas appear to give promise of holding bonanza deposits that can be won easily and cheaply. Necessarily, the individual's experience, enterprise, and desire will determine the sort of search he can undertake most successfully, but it must not be forgotten that it is of prime importance that the newcomer should at least be provided with sufficient funds to defray his living expenses during the time required to obtain employment or find a deposit that will afford some income. It must be remembered, too, that all costs in most parts of Alaska are higher than they are in communities of similar size in the States proper; that the season when there is need for the employment of many persons in most places, does not last more than 3 or 4 months; that for one dependent on his current earnings sufficient income must be procured during the short working season to tide over the 8 months or so when jobs are extremely scarce; and finally, should the venture not turn out as well as hoped, that return to the States necessitates a considerable outlay of money for transportation.

General conditions affecting placer-gold mining were on the whole normal throughout 1939, though obviously diverse conditions prevailed temporarily in different camps throughout the wide expanse of territory in which placer mining is done. For instance, operators in many parts of east-central Alaska, such as the Fortymile and Circle districts, western Kuskokwim region, and the Yentna district of the Cook Inlet-Susitna region, reported average or better than average supplies of water for mining. Other operators in the Tolovana, Iditarod, Koyukuk, and Fairbanks districts reported less than normal water supplies. In fact, in the Koyukuk, many of the streams were reported to stand at lower levels than had heretofore been recorded. Although the Fairbanks district is recorded among those deficient in water, this condition existed only in the earlier part of the season, because later there was at least normal precipitation. It is interesting in this connection to note that about the time that operators 
in the Fairbanks and Tolovana districts were complaining of shortage of water, miners in the Rampart and Bonnifield districts, only a relatively short distance northwest and south, respectively, of Fairbanks, reported an undesirably large amount of water. A like condition prevailed in the Koyukuk district, where, in spite of abnormally low water in most of the district, there was especially high water in parts of the Alatna River Valley. In making the foregoing generalizations the writer does not mean to imply that many of the miners, even in the areas considered to have average or better water supplies, were satisfied with the amounts available at their individual properties, for there is always the tendency of the operator not only to plan to use the entire available supply but also to overestimate that supply. Less dependence is now placed on the normal gravity supply of water by the larger operators and more and more reliance on the use of pumps to augment or even to replace that supply. Consequently, unless extremely adverse conditions arise, the total production of gold from the placers is increasingly less directly affected by shortage of precipitation than heretafore: This lessening dependence on climatic conditions holds true also for the so-called freeze-up and break-up, because with increased transportation facilities many of the miners can get to their properties earlier and remain on them later and thus make a longer working season. Then, too, the extensive use of thawing equipment at all of the larger properties makes it possible to lengthen the working season by starting earlier in the spring and closing later in the fall.

Labor conditions on the whole were satisfactory, and at all times there was an adequate supply of labor available, though often not of as skilled or dependable a type as when there were fewer transient workers. The anticipated difficulties in operating under the recently enacted wages and hours law turned out to be less than had been feared, because placer miners in Alaska and in some of the States were exempted from certain of the general provisions. The necessity for making certain exceptions for Alaska miners is obvious when one takes into consideration the shortness of the working season in the Alaska placer fields and the acute shortage of jobs during the period that these miners must of necessity be idle.

\section{PRODUCTION BY DISTRICTS}

The description given on pages 1-4 of the methods used in collecting and interpreting the information that forms the basis of this report indicates that it is more difficult to obtain accurate facts regarding the production of placer gold than regarding any of the other mineral commodities. This is due to the great number of small 
producers, who are widely scattered, many being in the most remote parts of the Territory. Frequently the gold they produce passes through many hands before it finally reaches a mint or assay office, so that a single lot is difficult to trace. It may appear in the reports of the individual and then lose its identity by being lumped with other gold by the storekeeper, who took it in exchange for supplies; it may be still further consolidated by the bank, perhaps in some distant district, to which it was sent by the merchant; and perhaps its course may be still further obscured by being shipped to another bank before being turned in to the mint; or the gold may be carried personally by the producer or sent by mail or express to its ultimate destination. Thus records from one source may entirely or partly duplicate those from other sources, whereas for other lots there may not be any definite records at all. Every reasonable effort has been made to check the information from different sources and to adjust recognized discrepancies so far as possible. As a result it is believed that the figures given for the total placer production are in accord with the actual facts. The distribution of this total among the different districts, however, is open to more serious errors, as gold produced in one district, unless reported to the Geological Survey by the original producer, may be credited to some other district through which it passed in the course of trade. In spite of the possibility of some error in the distribution of placer gold among the different regions, the following table has been prepared to show the comparative standing of the different regions as accurately as possible. It should be remembered that in this table, like all other tables in this volume that relate to production of gold in periods subsequent to 1934, all statements relating to the value of the gold are based on the present standard price of $\$ 35$ an ounce.

In the following table the different regions are arranged in geographic order from southeast to northwest. As has so long been the case, the largest amount of placer gold came from the Yukon basin and the next largest from Seward Peninsula. Placer mining in each of these main regions is discussed in some detail in the following pages, and the more notable events of the year are recorded for each region.

Value of placer gold produced in Alaska in 19.99 and 1998

\begin{tabular}{|c|c|c|}
\hline & 1939 & 1938 \\
\hline $\begin{array}{l}\text { Southeastern Alaska. } \\
\text { Copper River region } \\
\text { Cook Inlet-Susitna region and southwestern Alaska } \\
\text { Yukon Basin } \\
\text { Kuskokwim region } \\
\text { Seward Peninsula and northwestern Alaska }\end{array}$ & $\begin{array}{r}\$ 5,000 \\
146,000 \\
214,000 \\
10,810,000 \\
1,283,000 \\
3,600,000\end{array}$ & $\begin{array}{r}\$ 4,000 \\
132,000 \\
348,000 \\
10,123,000 \\
803,000 \\
3,487,000\end{array}$ \\
\hline$\therefore \quad$ Total & $16,058,000$ & $14,897,000$ \\
\hline
\end{tabular}


Although southeastern Alaska is rich in lodes of gold and other metals, its placers are of relatively small extent and yield only a little gold, because throughout most of the region the topography is mountainous, with precipitous slopes leading down from the crests of the ridges to the ocean waters or to the valley floors, thus affording little or no lodgment for detrital material. Furthermore, so much of the region was occupied in the relatively recent past by glaciers that there is an almost complete lack of deposits produced through the long-continued sorting action that is so essential for the formation of rich placers. Even along the coast there are almost no beaches where concentration has long been effective. In the lowlands of the larger streams, in some of which great amounts of detrital material have been dumped by past geologic processes, sorting action such as is conducive to the formation of rich placers has been relatively slight, and much of the material handled by the streams has not been subjected to weathering and similar processes, which unlock the mineral grains of different kinds and thus promote their separation through physical differences. There is, therefore, small likelihood that southeastern Alaska as a whole holds much promise as a placer region, though in a few places where special geologic conditions prevail there is a chance of finding in restricted tracts placers of value.

The entire placer production from southeastern Alaska in 1939 is estimated to have been worth only $\$ 5,000$, so that even the largest operations were small camps of two or three men each, who took out only enough gold to make a very modest grubstake. There are three areas in southeastern Alaska in which, in the past, placer mining has been active-near Juneau, in the valley of the Porcupine River, and on the beaches between Lituya Bay and Yakataga. No placer mining is reported to have been in progress in either the Juneau or the Porcupine districts in 1939. In the Lituya-Yakataga district placer mining was continued on about the same scale as for several years. The placers there are all of the beach type, exposed to the waves of the Pacific Ocean. This position, though in a measure favorable for concentration of the beach material, is in general disadvantageous, because only under suitable weather conditions can the placers be mined, and even then the use of extensive mechanical appliances is precluded by the necessity of removing them during times of storm.

COPPER RIVER REGION

In the Copper River Valley there are two principal areas and one minor area that have yielded placer gold, though a few small camps 
are widely scattered elsewhere throughout the river basin. The principal areas, named in order of their production, are the Nizina and Chistochina districts, and the minor area is the Nelchina district. The value of the placer gold produced from the Copper River region in 1939 was $\$ 146,000$, an increase of about $\$ 14,000$ over that from the same region in 1938. This is an especially encouraging record, because 1938 was a year of considerably better than average production.

The greater part of the gold from placers in the Nizina district came from the properties of the Nicolai Placer Mines, on Dan Creek, and of the Andrus estate, on Chititu and Rex Creeks. At least two other smaller camps were mining on Rex Creek. The larger enterprise, on Dan Creek, employed an average of 15 men during the open season. Mining is carried on there by hydraulicking an old channel on the northern slopes of Dan Creek above Boulder Creek. In the course of that work a number of nuggets of native copper were disclosed in the gravels. In 1939 one of the largest, if not the longest, masses of native copper that has been found in Alaska was found in the course of placer-gold mining at this property. This mass was estimated to weigh 3 tons. At the Chititu Mines 17 men were employed mining deposits in a bench of Rex Creek. Mining for the season on this property is reported to have started on April 15, an unusually early date for beginning work in this district.

The Chistochina district embraces a rather large indefinite area on the southern flanks of the Alaska Range at the head of the Copper River, extending for some 50 miles eastward from the Richardson Highway. The principal placer mining activity in this district was that of the Slate Creek Placers, Inc., which, under the management of J. M. Elmer, is developing a large number of claims on State Creek. Algren and associates were also reported to have been hydraulicking other claims on Slate Creek and on its tributary, Miller Gulch. No placer-gold production is reported to have come from the properties of the Middle Fork Mining Co., on Middle Fork of Chistochina River. On Ahtell Creek and its tributary, Grubstake Creek, which are tributary to Slana River, some hydraulicking was done by Lyons and associates. During the mining on this claim a promising-appearing gold-quartz lode is reported to have been uncovered.

In the Nelchina district, which is in the extreme western part of the Copper River region and is most conveniently approached by way of the Matanuska Valley, tributary to Cook Inlet, all the placer mining was done by a few small camps, consisting of only two or three men each. The mining centered mainly around Albert Creek, and the total production, although greater than in 1938, amounted to only a few thousand dollars. 
The Cook Inlet-Susitna region, as the ter mis used in this report, includes the placer camps in Kenai Peninsula and adjacent country, the Yentna-Cache Creek district, and the Valdez Creek district, near the head of the Susitna River. For convenience, the small placer production from southwestern Alaska has been included with that of the Cook Inlet-Susitna region. In parts of this region were some of the earliest and most productive of the gold-placer camps of this Territory. Many of these old camps have gradually played out and been superseded by camps that have sprung up in new areas, and many of these too have now waxed and waned. Of late years, however, there has been a marked increase in the placer-gold production of some of the districts, though in 1939 the value of the gold production, from the region seems to have fallen off, being more than $\$ 130,000$ less than that of 1938 . In making this estimate it should be stated that the writer feels that it is more likely to be an undervaluation for this than perhaps for any other Alaska placer region. The reason for this is that there are a great number of small producers widely scattered throughout a vast tract of country that is known to be mineralized, and that many of them do not supply the Geological Survey with first-hand information as to their season's work. As a result, such records as are obtained from other sources, such as banks, assay offices, and express shipments, may be interpreted incorrectly, so that due credit is not given to some of the gold that passes through their offices as really having come from this region.

In the relative order of their placer production in 1939 the districts in the Cook Inlet-Susitna region ranked as follows: YentnaCache Creek, Valdez Creek, Kenai Peninsula and vicinity, and other miscellaneous scattered small placer camps, including southwestern Alaska.

The most productive part of the Yentna-Cache Creek placer district centers around the Dutch and Peters Hills, which form part of the southern foothills of The Alaska Range and lie some 25 to 35 miles west of the stretch of the Alaska Railroad that lies between Talkeetna and Curry. In general the productive placer creeks flowing from these hills are tributaries of Peters, Cache, or Granite Creeks, all of which ultimately join Kahiltna River. Peters Creek. and its tributaries drain most of the eastern part of the area, and the main stream follows a circuitous course, first southeastward and then southward to its junction with Kahiltna River. Its principal tributaries on which placers were mined are Bird, Willow, and Poorman Creeks. Westward, across Kahiltna River on the eastern slopes of the mountain area in which Mount Fairview is one of the domi- 
nating peaks, are several other streams on which placer deposits occur. This tract, which is locally known as the Fairview area, is here considered as part of the Yentna-Cache Creek district. No mining is reported to have been in progress in 1939 on the main Tokichitna River or on any of its tributaries that lie to the north of Peters Creek and in part traverse or rise in the same group of hills that form the highlands in which that stream also rises. In this large district there are about 25 properties at which about 75 men were employed and some mining was done in 1939. Of these the largest producer in the valley of Peters Creek and its tributaries was the Spokane-Peters Mining Co.; in the Cache Creek area, the Cache Creek Mining Co.; and in the Fairview area, the mine of Devault, Devault \& Leitz, on Pass Creek.

In the Valdez Creek district, which lies some 125 miles north of Anchorage, near the head of the Susitna River, and about 50 miles in an air line east of the main line of the Alaska Railroad, prospecting for both lodes and placers has been going on for many years, but in 1939 work had been discontinued on the lodes; and only four or five placer camps were active. The two principal outfits mining in the district are Carlson and associates on the Folk bench claim and the Tunnell Mining Co. on the Joplin bench claim. At the Joplin claim the operators during the winter of 1938-39 completed a shaft 180 feet deep through the old high-level channel deposits to reach the pay gravels that will be mined by drifts. At the Folk claim mining was done by hydraulicking, and it proceeded along the same lines as had been followed in recent years. Claim No. 4 above, on Valdez Creek, was also mined on a small scale during 1939, and there was one outfit each on Lucky Gulch and White Creek. It may be of interest to note that mining on one of the claims in this districtwas carried on successfully by several native Indians, who have shown a real aptitude for the work and have made a good living through their efforts in recovering the placer gold.

The producing placer camps in the Kenai Peninsula region are mainly in the vicinity of the settlements of Hope, Sunrise, and Girdwood. In the area near Hope and Sunrise there are more than a dozen properties on which some productive mining was in progress. Although perhaps some of these may have changed management, they have been consistent though small producers for many years and seem still to return reasonable compensation for the work done on them. No notable new developments are reported to have been made in the area during 1939 , and mining seems to have gone ahead at about the same rate as during recent years. Among the places where mining or prospecting was specially active may be mentioned Mills Creek and nearby creeks, south of Sunrise, and Resurrection 
Creek and its tributaries, south of Hope. On Mills Creek were the Seward Placer Co. and the Moose Pass Placers, Inc. On Resurrection Creek were the outfits of the Hope Mining Co. and of Richards, Mathison, and associates, as well as two smaller camps on its tributaries, Palmer. and Bear Creekș. Perhaps the item that caused the most comment in the district was the extensive drilling campaign undertaken by N. C. Stines in that part of the valley of Kenai River between Cooper Creek and Russian River and near Canyon Creek and at Sixmile River near Sunrise. No details as to these projects have been made public, but the fact that the work is being directed by one so long and successfully identified with placer developments throughout the world gives good ground for assuming that the project will be thoroughly tested and that if development work is undertaken it will be carried out with technical skill and adequate financial support.

In the Girdwood district, which lies north of Turnagain Arm and includes the valley of Glacier Creek and its tributary Crow Creek and somewhat farther west the valley of Bird Creek, the largest producing camp was that of Peterson \& Mayfield, who were mining under lease part of the claims that heretofore have been developed by A. S. Erickson, about 4 miles north of the small settlement of Girdwood. Nearer the head of Crow Creek, Axel Lindblad and later Jack Wadman spent most of the season of 1939 in deadwork, getting the surface plant into shape and doing such prospecting and testing as would enable the owners to formulate a suitable plan for development.

A small production of placer gold is also reported to have come from a few scattered camps south and west of Kenai Peninsula. Of these camps, those that reported their work to the Geological Survey were in the vicinity of Lake Iliamna and on Kodiak Island. The only placer mining in the vicinity of Lake Iliamna is that of Fred Bowman, on Portage Creek. Mining at this place was not started until late in the season and consisted in hydraulicking the local stream gravels. On Kodiak Island the placer workings were confined almost exclusively to the beach and coastal plain deposits near Red River, on the southwestern coast of the island. Here at times as many as five to seven men employed their leisure time in simple hand methods of washing the gold from the sands. For all practical purposes it may be considered that no serious attempts to develop any of the potential placers of the region have been made, but that the amount of gold recovered by the desultory work done indicates that placer gold occurs there in quantities that would warrant a more thorough search for deposits that might be mined at a profit. 
YUKON REGION

The Yukon Valley embraces a tremendous extent of territory, and scattered through it from one end to the other are placer-gold camps. In the past gold has been reported from almost every stream in the entire basin, though the quantities in some have been so small as to be of no commercial significance. For convenience of description in this report, all the producing placer camps in this vast area have been grouped into more or less distinct tracts that are here called districts. It should be noted that the boundaries of these districts are by no means well defined and do not necessarily correspond to any of the legal subivisions, such as precincts or recording districts. In the main, the names here given to these districts have been chosen from some of the more prominent features occurring in them. The chief purpose of this grouping is to combine areas having in general similar interests and similar conditions and to separate those that are dissimilar. This results in throwing some large tracts together and in splitting up some other parts of the Yukon Valley into several small districts. In some places the boundaries of the different districts almost overlap; in others the boundaries of one district lie far from those of its nearest neighbor.

The placer gold from all the camps in the Yukon Valley in 1939 had a gross value of $\$ 10,810,000$ which is $\$ 687,000$ more than in 1938 , when the value was $\$ 10,123,000$. This large increase is not to be attributed to any specially favorable condition but is largely due to the coming into full production of several new enterprises that have been in the course of development during preceding years and to the more extensive utilization at many of the older properties of modernized mechanical equipment capable of handling larger volumes of placer material more effectively. It cannot be viewed as a mere temporary spurt resulting from some spectacularly rich finds but marks rather a rate that, under reasonably expectable conditions, will be maintained, if not bettered, in the next several years.

In the following table the districts are arranged in order of their placer production in 1939, and for comparison the production from the same districts in 1938 are given. The total is believed to be correct as stated, but the distribution of this total among the districts is open to some uncertainty, owing to the great number of small producers, their wide distribution, and the failure of some of them to supply the essential information. However, every reasonable precaution has been taken to guard against serious errors and to keep the estimates in accord with all the available facts, so that the figures stated are regarded for all practical purposes as accurate and comparable with similar figures for earlier years. 
Value of placer gold produced in Yukon Basin, 1939 and 1998, by districts

\begin{tabular}{|c|c|c|c|c|c|}
\hline District & 1939 & 1938 & District & 1939 & 1938 \\
\hline airb & \multirow{9}{*}{$\begin{array}{r}\$ 6,041,000 \\
1,398,000 \\
776,000 \\
638,000 \\
421,000 \\
396,000 \\
341,000 \\
226,000 \\
216,000\end{array}$} & \multirow{9}{*}{$\begin{array}{r}\$ 5,653,000 \\
1,477,000 \\
741,000 \\
629,000 \\
263,000 \\
372,000 \\
234,000 \\
241,000 \\
302,000\end{array}$} & \multirow{9}{*}{$\begin{array}{l}\text { Bonniffeld and Kantishna } \\
\text { Koyukuk } \\
\text { Rampart } \\
\text { Chisana } \\
\text { Eagle } \\
\text { Chandalar } \\
\text { Fort Gibbon } \\
\text { Total }\end{array}$} & \multirow{7}{*}{$\begin{array}{r}\$ 188,000 \\
92,000 \\
31,000 \\
20,000 \\
18,000 \\
8,000 \\
(1)\end{array}$} & \multirow{7}{*}{$\begin{array}{r}\$ 75,000 \\
59,000 \\
8,000 \\
29,000 \\
21,000 \\
3,000 \\
16,000\end{array}$} \\
\hline & & & & & \\
\hline Iditarod. & & & & & \\
\hline Innoko.- & & & & & \\
\hline Marshall & & & & & \\
\hline Hot Springs. & & & & & \\
\hline Fortymile & & & & & \\
\hline $\begin{array}{l}\text { Tolovana... } \\
\text { Ruby }\end{array}$ & & & & 10.810 .000 & $10,123,000$ \\
\hline & & & & & \\
\hline
\end{tabular}

1 Not shown separately.

The foregoing table presents in condensed form a comprehensive summary of the general placer-mining situation in the Yukor region in 1939 as contrasted with that in 1938. From this table it will be readily evident that the value of the output in 1939 was $\$ 687,000$ more than in 1938. The individual districts differed greatly in their contribution to the total for the region and also in the amount that each produced in the different years. On the whole, however, the increase was distributed among all of the large producing districts, and the only decreases recorded were relatively small or occurred in the smaller producing districts. Only five districts showed a falling off in their placer-gold production, and the total amount of their decrease was less than $\$ 200,000$. Information as to the principal happenings of the year in each district is given in more detail in the following pages. The order in which the districts are taken up corresponds to the order given in the above table, namely, in the order of the value of the placer-gold production in 1939.

The indefinite tract of country adjacent to Fairbanks, here called the Fairbanks district, has long been and still is the main placer district in Alaska. In 1939 it furnished nearly 56 percent of the placer gold produced from the entire Yukon region and approximately: three-eighths of the entire placer gold produced from Ala'ska placer mines in that year. This is an especially good showing, because in that district during most of the early part of the season there was less than the normal supply of water available for mining. Furthermore, several of the projects that are in the course of development have not yet reached the stage of making any returns in placer gold for the outlays of work and money that have been put into them. On all sides there was evidence of work in progress that was only preliminary to increasing the production another year. This is especially the situation with regard to the most extensive development.in progress in the district, which has already been vigorously under way for several years and will probably not come into production for still another year or so. 
The greatest amount of gold from the district was produced by the Fairbanks Exploration Department with its six dredges on Goldstream, Pedro, Cleary, and Ester Creeks, and its scattered small hydraulic plants. One other company, the Deadwood Mining Co., was engaged in dredging in the district. Its dredge is situated on Nome Creek, which, although considered by some as being in the Tolovana district, is treated in the Survey reports as part of the Fairbanks district. Considerable placer gold was also recovered by several other companies using hydraulic, open-cut, and drift mining methods. Placer gold recovered by the smaller operators, using other methods than dredging, came principally from Goldstream and its tributaries, Gilmore, First Chance, Nugget, Eldorado, and Happy Creeks; from Chatanika River and its side streams or their tributaries, Dome, Vault, Cleary, Wolf, Kokomo, Faith, and Sourdough Creeks; from Chena River and its side streams or their tributaries, Fairbanks, Pearl, Fish, and Palmer Creeks; and from Caribou Creek, a tributary of Salcha River. There were also smaller camps in the valleys of a number of the other streams, whose production, though individually only a few hundred or a few thousand dollars, in the aggregate swelled considerably the total production for the district.

The extensive mining project being carried on by the Fairbanks Exploration Department, embracing large tracts on Goldstream, Cleary and Ester Creeks, continued to be the outstanding placermining enterprise, not only in the Fairbanks district but throughout the Territory. The placer work of this company in 1939 is divisible into several more or less separate enterprises that are closely knit together in their broader aspects. Three of these enterprises embrace the mining in progress by three modern dredges on Goldstream and Pedro Creeks, two dredges on Cleary Creek and Chatanika River, and one dredge in the headwater of Ester Creek. The work on Goldstream and Cleary Creeks was essentially a continuation of the dredging that had been in progress on these streams for several years. At both of these projects water for mining was supplied mainly by a long ditch line that picked up its water far up the Chatanika River and led it by ditches, flumes, and gigantic siphons to the areas where it was put to work. The dredging on Ester Creek was essentially a continuation of the work that had been started in 1937 near the head of the creek and subsequently carried downstream as far as conditions permitted during each year. A fourth enterprise of major significance, though not yet yielding gold, was the continuation of the preparatory work that has been in progress for 5 years in removing the overburden and thawing the underlying gold-bearing gravels of an enormous tract on Cripple Creek, near its junction with Ester Creek. This project has required the re- 
moval of tens of millions of cubic yards of non-gold-bearing material and the installation of the devices requisite for supplying and distributing an adequate supply of water for the various hydraulic processes and the disposal of the waste products created thereby. Water for most of this development work is pumped from Chena Slough to a high ditch line nearby. By means of this ditch and accessory siphons the water is distributed to the different parts of the area as needed. The stripping part of this program has already been practically completed, and the thawing of the part of the area to be mined is well advanced.

During 1939 much of the removal of overburden which lay below the effective grade level that could be maintained for surface run-off was handled by a large dragline equipped with a boom 165 feet long from which a 12-yard bucket was swung. The material from the dragline is dumped on a conveyor system and disposed of at points a mile or so distant, where it will be out of the way of subsequent work: Late in the fall shipments of parts for a large dredge that is to be built for mining this area began to arrive at the point where they are to be assembled. Construction is to be expedited as much as possible, but it will be well into the summer of 1940 before the entire operation will be in full swing. A rather complete description of many of the mechanical features of this project has recently been published in one of the technical journals. ${ }^{6}$ Two other somewhat comparable pieces of preparatory work, although on a somewhat smaller scale, were also in progress by the Fairbanks Exploration Department on Fish Creek and near the junction of that stream and Fairbanks Creek and on Little Eldorado Creek. In the Fish CreekFairbanks Creek area the company had acquired the equipment and claims of most of the earlier operators in the tract, and it has been active for more than 2 years in unifying all its holdings in that neighborhood and bringing the whole tract into shape for mining as rapidly as practicable. Extensive stripping operations were carried on, and considerable progress was made in thawing the placer gravels. Essentially similar. work was done on the company's property on Little. Eldorado Creek.

In emphasizing the preparatory work that is in progress by the Fairbanks Exploration Department in the Cripple, Eldorado, and Fairbanks Creek areas, it should not be overlooked that a similar type of preparatory work, though by no means on as gigantic a scale, has been and is still in progress in the so-called producing areas on Goldstream, Cleary, and upper Ester Creeks. It takes the company at least 3 years to prepare a tract for dredging, as the

\footnotetext{
- Stripping 55 million cubic yards of Arctic orerburden: Mining World, vol. 2, pp. 2-8, February 1940.
} 
surface vegetation must be taken off, the overburden thawed and disposed of, and the frost in the gold-bearing gravel thoróughly removed before it can be excavated. All of these processes are going on simultaneously in different parts of these so-called producing areas as an integral part of each dredging project, and therefore they have not been counted separately in listing the major undertakings of the year by this company.

At several points in the Fairbanks district the company's holdings, either because of the isolation of the tracts or because they could not be reached handily by the dredges in their regular course, have been mined by small hydraulic plants. The principal operation of this sort is that near the junction of Goldstream and Gilmore Creeks, where a combination scraper and hydraulicking plant was mining throughout most of the open season on old gravels on the right side of the valley too high above the general grade of the valley floor to be reached by the dredges that have mined in the neighborhood.

In addition to these various enterprises carried on by the Fairbanks Exploration Department, which are now yielding placer gold or give definite assurance of returning gold in the immediate future, the company does an immense amount of drilling each year to test areas whose prospective values have not yet been determined. Many of these tests are carried on in places far removed from the Fairbanks district. In the Fairbanks district the principal place where prospecting work of this sort was done by the company in 1939 in areas not immediately adjacent to its older properties was in the western part of the Goldstream valley, in the vicinity of Sheep and Little Nugget Creeks.

In naming the creeks in the Fairbanks district from the valleys of which most of the placer gold came, it may not have been evident that in the main the greater number of these lie within a radius of 10 to 20 miles from Fairbanks. The occurrence of placers, however, is not restricted to this small tract; actually they are much more widespread throughout the district, and some of the isolated mining camps might be treated as separate districts or areas if it were not for the fact that such treatment would not have served any useful purpose, because, owing to the small number of operators in some of these camps, it would not have been permissible to record their production separately. How widely some of these outlying camps are scattered through the district may be learned from the following notes on some of those that are more than 20 miles from Fairbanks. The hydraulic plant of A. A. Zimmerman on Kokomo Creek, a tributary of the Chatanika River, some 25 miles in an air line northeast of Fairbanks, and another outfit belonging to the same operator on 
Sourdough Creek, some 50 miles northeast of Fairbanks, had a successful season. The dredge on Nome Creek, which was referred to on p. 40, is situated not far to the northwest of the camp on Sourdough Creek. This diredge was formerly used on Deadwood Creek in the Circle district-and hence the name of its operating company-but was moved and erected at its new site early in the season, so that by July 14 it was again in operation and continued dredging until November 4. The ground being dredged is said to be naturally thawed, so that the heavy outlay required for artificial thawing of most of the other deposits in the district is avoided. Two small camps were mining on Faith Creek, about 55 miles in an air line northeast of Fairbanks. About 65 miles east of Fairbanks, in the valley of Chena River, some placer mining was in progress near the head of the main stream and on Palmer and Shamrock Creeks. On Caribou Creek, a tributary of Salcha River, some 55 miles east of Fairbanks, the Caribou Gold Dredging Co. was busy during most of the open season in further testing of their placer claims and rechecking some of their earlier records. It is understood that the results of this new work were even more encouraging than those that had been made previously, so that definite steps were taken to arrange for the construction of a dredge, which will be put on the ground early in 1940. Even in so remote a camp as the old Tenderfoot or Richardson area, which lies some 75 miles east of Fairbanks, some placer mining was in progress, though according to reports it was on only a very small scale and yietded littlemore than an extremely modest grubstake.

Although the placer gold production from the Circle district in 1939 showed a falling off of about $\$ 79,000$ from the high mark set in 1938 , that decrease in value was only approximately 5 percent and is regarded as an entirely expectable fluctuation that might readily be accounted for by any one of several purely temporary causes. Considerably more than half of the output of placer gold from the Circle district in 1939 came from three dredges-on Coal and Woodchopper Creeks, in the extreme northeastern part of the district near Yukon River, and on Mammoth Creek in that part of the district near Mastodon Dome. Most of the dredges reported an especially satisfactory season in which there had been rather better than average working conditions, though at the Berry dredge some interruption resulted from a fire that took place in mid-September. As was noted on p. 40, the dredge of the Deadwood Mining Co., which was active in the Circle district in 1938, was no longer in operation there in 1939 but had been removed to Nome Creek, in the Fairbanks district. Operators mining with other equipment than dredges were working on almost every creek in the district. Many of these had installed 
draglines, bulldozers, and other mechanized equipment by which they were able to handle large quantities of placer material efficiently. Some effective work was also done with hydraulic plants.

Even many of the smaller camps using little mechanical equipment had good returns on their season's work. It is impracticable at this place to record all the creeks in the Circle district on which placer mining was in progress or to name the various operators. A rough estimate of the number of men employed in the mines of the district places the figure at between 300 and 400. Apparently there was more unemployment in this district during the height of the working season than in most of the other Alaska placer camps. Possibly this was due only to the remoteness of the camp, which made it difficult for those that could not find employment there to get away without assistance. The greatest production other than that from the dredges came from mines on Mastodon, Mammoth, Independence, Eagle, Ketchem, Portage, Porcupine, and Harrison Creeks, with smaller amounts from mines on Deadwood, Switch, Miller, Bottom Dollar, and Half Dollar Creeks. It was interesting, in compiling the impressions of various operators as to the amount of water available for mining during the season, to note the wide difference of opinion. Many reported better than normal amounts, although others stated that their operations were severely curtailed by a shortage during part of July and August. Those reporting an inadequate supply were mainly the smaller operators, who were generally dependent on local natural sources. There was a continuation of the drilling campaign by the Fairbanks Exploration Department, which was started in 1938 , but no public announcement has yet been given out as to the results of these tests.

Third place among the various placer districts of the Yukon region in 1939 continued to be held by the Iditarod district, which yielded some $\$ 776,000$ in gold as a result of the season's mining, or about $\$ 35,000$ more than in 1938. A considerable part of this total came from the dredges of the North American Dredging Co. and the J. E. Riley Investment Co., both of which were mining on Otter Creek not far from the town of Flat. Both of these dredges have been in service for a long. time in this general area. It is understood that new steel pontoons and much accessory equipment were brought in toward the close of the season to be used in almost completely rebuilding the hull and part of the machinery of the present North American dredge. The Riley dredge underwent a very thorough overhaul in 1938, so that it is now in shape for many more years of useful service. Altogether between 250 and 300 men, including those employed by the dredging companies, were employed in the placer mines in the Iditarod district. Specific de- 
tails regarding the work accomplished at many of the properties during the year have not been furnished the Geological Survey by the operators. It appears, however, that in the main, work was continued at most of the places where large camps had been established for some time and that there were no notable areas opened up in the district. At most of these larger camps, draglines, bulldozers, and other mechanical equipment enabled the miners to handle large amounts of placer material efficiently and economically. From general reports it was learned that climatic conditions were not quite as favorable during 1939 as they were in 1938, because the supplies of water were deficient during the early part of the season. Also, the season did not open quite as early in 1939 as it did in 1938. Though many of the larger camps had their work under way early in May, this did not equal the record set in 1938, when one camp started work on April 24-the earliest recorded date for starting this work in the history of the district. All of the larger camps are within a radius of about 10 miles of Flat, but many of the smaller one- or two-man camps are widely scattered at more remote points throughout the district. Among the largest producing camps in the district, exclusive of those of the dredging companies, are the following: On Otter Creek, Peter Miscovich; on Flat Creek, Durand \& Awe Bros. and Patrick Savage; on Slate Creek, Uotila and Ogriz; on Willow Creek, the Northland Development Co. and Iditarod Mining Co.; on Happy Creek, Olson \& Co.

Reports from the Innoko district indicate that the output of placer gold from that district in 1939 was about $\$ 9,000$ greater than in 1938 . As usual, a large part of the gold that was recovered came from the four dredges that are mining in the district. Two of these were on Ganes Creek and one each on Yankee and Little Creeks. The production from these dredges appears to have been practically identical in 1939 and 1938. Doubtless it would have been somewhat greater, but an unfortunate accident, which caused the sinking of the Holky dredge, cut nearly a month off its productive season. Happily the damage to the boat was not serious; it was raised and the necessary repairs will be made so that the dredge will be ready for a full season in 1940. The Innoko district, as referred to in these reports, embraces a very wide expanse of territory, including practically all that part of the valley of Innoko River that lies east of its junction with its tributary, Dishna River. In this great district there are three more or less distinct centers around which mining has developed. These are the country adjacent to the settlement of Ophir, near the head of Innoko River; an area near Tolstoi, some 25 miles northwest of Ophir; and an area in the extreme eastern part of the district, in 
the vicinity of the Cripple Creek Mountains. All of the dredges are in the Ophir area. The other principal mining companies in this area are Uotila and Hard and Eric Hard, on Ophir Creek; Matheson \& Savage, on Spruce Creek, a tributary of Yankee Creek; Frank Speljack, on Ganes Creek; and Vibe and Schwaesdall, on Spaulding Creek. In the Tolstoi area the principal placer production was by the Three Miners, Inc., on Esperanto Creek. In the Cripple Creek area the larger operators were the Cripple Creek Mining Co., on Cripple Creek, and Hard, Uotila, and Hansen, on Colorado Creek. In addition to these larger, more fully mechanized camps, there were several hydraulic outfits mining on a somewhat smaller scale but apparently having a highly successful season. There were also a number of very small camps using mainly hand methods and employing only one or two men each at widely scattered points throughout the entire district. In fact, it was apparent that mining and prospecting was much more active throughout the district in 1939 than it has been for several of the immediately preceding years.

An increase of about 66 percent over the previous year's production marked the production of placer gold from the Marshall district. in 1939. This increase from $\$ 263,000$ to $\$ 421,000$ raised the Marshall district from seventh place in the list of districts in the Yukon region in 1938, rated on the basis of their current production, to fifth place in 1939. This makes the third great increase in production in succession from this district, as in 1936 its placer gold production was estimated to have been only $\$ 72,000$. The Marshall district, as the name is used in this report, includes practically all of the western part of the Yukon Valley below Holy Cross and is somewhat more inclusive than the so-called Wade Hampton recording precinct. In this large area of relatively little placer mining or prospecting, activity was more or less localized at three points-one near Marshall, another in the vicinity of Kako Creek a short distance north of Russian Mission, and the third in the Stuyahok or Bonasila Valley. The greatest production in the immediate vicinity of the settlement of Marshall came from Willow and Disappointment Creeks, 10 to 15 miles southeast of Marshall. The largest camp on Willow Creek was that of Johnson \& Ostnes and on Disappointment Creek that of the Wilson Creek Mining Co., A. S. Erickson, manager. The Erickson company mined with a dragline and elevated sluice boxes and employed an average of 13 men throughout the season. In the vicinity of Kako Creek, which joins the Yukon some 50 miles due east of Marshall, the Yukon Mining Co. was mining throughout 1939 on Bobtail Creek, a tributary that joins Kako Creek about 4 miles from the Yukon. This company, mining with a dragline and dumping into elevated sluice boxes, employed an average of 12 men. 
Shortage of water during most of the season necessitated return of the water after it had been used once for sluicing; this, together with the early closing of the season in the fall, reduced the company's expected output considerably.

About 50 miles northeast of Marshall, but still in what is here considered within the Marshall district, in the valley of Flat Creek, a tributary of the Stuyahok River, itself a tributary of the Bonasila River, Vance Hitt and associates continued the work on the property that had been in progress for several years, and they feel that they have already proved enough placer ground ahead of them to assure the continuance of the project for many years. The mining is mainly done with draglines, and it afforded employment for a considerable crew.

The Hot Springs district, as the term is here used, consists of two rather widely separated tracts-one including the western part of the district from Tofty to Woodchopper Creek and extending as far west as American Creek, the other including the eastern part, which centers around Eureka Creek and is locally referred to as the Eureka Creek area. In spite of the fact that this district increased its production in 1939 over that of 1938 , when it held fifth place among the large producing districts of the Yukon district, it was forced to drop back in 1939 to sixth place among those districts. A considerable part of the gold from this district was recovered by dredging. The dredge was that of the American Creek Operating Co., on American Creek, in the extreme western part of the district. In the Tofty area the largest placer production, exclusive of that obtained by dredging, came from the properties of the Cleary Hill Mines Co., in the valley of Sullivan Creek, and of Adolph Bock, on Deep Creek. At the Cleary Hill claims mining is done with a dragline and bulldozer; at the Bock claims mining by drifting is the method used. Smaller production of placer gold in this area was reported by other operators on American; Woodchopper, Boulder, and Cache Creeks. In the Eureka area the largest production came from Omega Creek and the benches of Pioneer Creek, with smaller amounts from Rhode Island and Eureka Creeks, Glen Gulch, and McCaskey Bar. The large outfit on Omega Creek, the Montana Mining Co., is the only one in the Eureka area with a dragline equipment. The rest of the operations were more or less evenly divided as to production between drift and hydraulic methods. Altogether, approximately 125 men were employed in the various mining enterprises in the Hot Springs district. Apparently, this district had an insufficient supply of water for mining purposes during much of the season, and its output of placer gold was thereby curtailed. 
In the Fortymile district the exceedingly good showing made in 1938 was considerably surpassed by the output of gold in 1939, when $\$ 341,000$ was produced, as against $\$ 234,000$ in the earlier year. By far the greater part of this production comes from two dredgesthose of the North American Mines, Inc., on Wade Creek, and the Boundary Dredging Co., on Canyon Creek. The dredge on Canyon Creek was a new boat that was only completed late in 1938, so that the current season was its first full year of mining, and its performance was regarded as highly satisfactory. The dredges of the Alaska Gold Dredging Co., on Mosquito Fork, and of the Walker Fork Dredging Co., on Walker Fork, were idle in 1939. Both of these companies became involved in financial difficulties, and their holdings were taken over by the Northern Commercial Co. in November and December 1938, but as yet no plans have been announced as to what disposal will be made of them. Although many of the other districts in the Yukon region were hampered by a deficient supply of water for mining in the early part of the season, many of the camps in the Fortymile district reported a better than average water supply. In addition to the dredge production from Wade Creek, there were three or four other placer mines in operation on that creek. Other creeks on which considerable gold was recovered by hydraulicking or open-cut methods were Lost Chicken, Chicken, Myers Fork, and Dome Creeks, as well as a score of other creeks where one- and two-man camps made little more than modest grubstakes. The usual number of old-timers searched for gold at favorable localities along the bars of the Fortymile River, especially during periods of low water.

The Tolovana district, as that name is used in this report, embraces a considerable tract of country lying north and northwest of Fairbanks. In it the greatest placer mining activity centers around the settlement of Livengood, which is about 80 miles by automobile road from Fairbanks. Reports indicate that during the early part of the season and even into August supplies of water for mining or even for domestic use were woefully deficient, though later the fall rains in part relieved that shortage: The principal item of interest to miners, not only in the Tolovana district but in many of the placer camps throughout the Territory, related to the extensive mining project that was started to develop the entire area contiguous to Livengood Creek. This project had been under consideration for several years but had encountered various difficulties, which had blocked its being carried out. Finally, in late summer, word was received that the Reconstruction Finance Corporation had granted financial support to the Livengood Placers, Inc., for going ahead with the work. The project contemplates the driving of a long tunnel through the 
low divide at the head of Livengood Creek so as to afford a channel through which part of the waters of Hess Creek can be diverted into the valley of Livengood Creek, and thus make available for mining the remaining placer deposits in that valley. It is understood that subsequently the plan calls for the installation of a dredge for the actual mining of these placers. When this program is carried out it will mean the elimination of small operators throughout the main valley of Livengood Creek. Much of the mining on the tributaries of Livengood Creek and the Tolovana River, however, will still continue to be in the hands of the smaller operators. All the important placer deposits on the side streams seem to occur in those valleys that radiate from a more or less common center near Amy Dome. These include Lillian, Gertrude, Ruth, and Amy Creeks, which flow into Livengood Creek, and Olive Creek, which flows directly into the "Tolovana River. A lesser amount of placer gold comes from deposits near Wilbur Creek, a stream that is tributary to the Tolovana River from the south, not far from Livengood Creek. Producing placer camps were active on all these side streams during 1939 . In the main these camps used hydraulic methods of mining, but several of them had added tractors and other mechanical devices to aid in the work, either for handling tailings or other transportation work or for pumping, and at one property a dragline plant was in use. In former years much of the placer gold had been recovered by drifting methods, but in 1939, except at one camp on Livengood Creek, one on Lillian, and one on Lucky Creek, this method does not seem to have been used in the district.

The Ruby district, as described in this report, is a rather ill-defined area extending southward from the settlement at Ruby, on the Yukon, for 50 to 60 miles and including the settlement of Poorman and the various camps adjacent thereto. There are two principal centers of mining activity in the district-one near Long, about 25 miles south of Ruby, and the other near Poorman, some 25 miles farther south. The principal producing creeks in the area near Long are Long Creek and its tributaries, Flat and Greenstone Creeks. On tributaries to the Sulatna River, downstream from its junction with Long Creek but within what may be considered the Long area, there has been placer mining on Spruce and Trail Creeks. The largest producing company in the entire Ruby district is the Long Creek Mining Co., on Long Creek, some 20 miles south of the settlement of Ruby. This company has extensive equipment on the property and is operating with a dragline and two bulldozers. Of four other smaller outfits, mining by hydraulic methods or shoveling into the sluice boxes, three were on Long Creek proper and one on Flat Creek. On Trail Creek most of the season was spent in preparatory work pending the 
installation of a dragline, which the operators are said to expect to have in operation next year. In the area adjacent to Poorman there was rather less productive mining in 1939 than heretofore. This was in large measure due to the acquisition by Vance Hitt, under lease or by purchase, of almost all the claims on Poorman Creek, so that the properties would be handled as a unit and mined on a large scale by a dragline. It is understood that much of the new equipment has already been freighted to the ground and that a considerable part of the season of 1939 was spent in carrying through the necessary negotiations and clearing up the preparatory work so that there would be little delay in getting into full operation in 1940. The largest producing camp in the vicinity of Poorman in 1939 appears to have been that of the Timber Creek Mining Co., on Timber Creek, which joins Poorman Creek from the south about midway between the settlements of Poorman and Placerville. This deposit is mined by drifting methods and is one of the few mines of that type still operating in the district, though formerly most of the mines were of that kind. Some mining was also done on Moose Creek, but it is understood that much of Moose Creek has been acquired by Vance Hitt as part of the project noted above. Only a little mining was in progress on Tamarack Creek, a tributary of Sulatna River, some 6 miles northeast of Poorman.

In the table on p. 39 the production of the Bonnifield and Kantishna districts has been combined. This seemed to be necessary if, as promised by the Geological Survey, the records of individual producers were not to be disclosed. By far the greater part of the placer gold production in each of these districts comes from a single operator, so that merging them with those of the several small producers in the two districts effectually carries out that promise. The two districts, however, will be described separately in the following notes.

The term "Bonnifield district" is applied in this report to a rather indefinite tract on the northern flanks of the Alaska Range lying between the Nenana River on the west and the Delta River on the east. Throughout much of the mining area the bedrock consists of highly metamorphosed schists cut by granitic intrusives. The camps in the district are widely scattered. The production in 1939 from this district showed an increase over that of the preceding year. The only large mine in the district is that of the Triple $\mathrm{X}$ Placers, on Moose Creek, a tributary of Nenana River, about 7 miles from the station of Ferry, on the Alaska Railroad. This property, under the management of E. W. Pringle, is being mined by a unique device patented by Messrs. Becker and Hopkins. This device is often referred to as a "one-bucket dredge," and the writer has been 
in somewhat of a quandary as to whether it should be classified in the tables accompanying this report among the dredges or among other mining operations. As the correct determination of the answer to this question is of little significance, except in this report, it really matters little what classification is adopted, and the writer has not included it among the dredges that are listed on pages 70-71. The single digging bucket has a rated capacity of $11 / 2$ cubic yards and operates from a boat with steel pontoons and from a boom about 25 feet long. The placer material is dumped from the bucket and slides into a trammel, from whence it feeds into the sluices, or the oversize goes to a conveyor belt and is rejected. The digging is done at the rate of about 2 buckets to the minute, and the rated capacity of the machine is 1,500 to 1,700 cubic yards a day, even in material containing a considerable number of boulders. The operators have an excellent opportunity for testing the efficiency of this machine as contrasted with a dragline, for the two are being used on the same property almost side by side. It is understood that the costs of operation of the dragline are more than three times those of this other machine. In addition to this large camp, the other producing placer camps in the district were situated on Totatlanika River and its tributaries; on Homestake and Marguerite Creeks; on Grubstake Creek, a tributary of Tatlanika River; and on Portage Creek, which is a tributary of the West Fork of Little Delta River. Some drilling and testing of the gravels of Rex Creek, a tributary of California Creek, was started. This is regarded as an especially significant move, because, if sufficient yardage of workable ground can be found, the operators propose to go ahead in a large way to develop it.

In the Kantishna district there was a great revival of mining activity through the operations of the Caribou Mines, on Caribou Creek, a tributary of Bearpaw River, at a point some 10 miles north of the old Kantishna post office. Mining at this place is being done with a dragline equipped with a $11 / 2$-cubic yard bucket. This placer material is washed in a separate unit with tractor treads, so that it can be placed readily in a convenient position with respect to the digging equipment. The large boulders, of which there are a considerable number in the gravel, are rolled or carted aside, but the smaller ones pass through the trommel on the washing plant and are rejected at the lower end. Bulldozers and other necessary equipment are available to aid as required. A good landing field close to the mine enables ready servicing of the camp: by airplanes, but the heavy machinery and supplies were brought in from Lignite, a station on the Alaska Railroad, during the late spring over the old trail that follows more or less along the northern foothills of 
the Alaskan Range. Among the other places in the Kantishna district where some placer mining or prospecting was in progress in 1939 may be mentioned camps on Moose Creek and its tributary, Eureka Creek.

The Koyukuk district, as the term is here used, embraces a very large tract of country and consists of at least three rather widely separated areas in which placer gold has been mined. These areas are the Indian River-Hughes area, in the central part of the Koyukuk Valley; the Hogatza River area, somewhat north of Hughes and embracing country north of the Koyukuk River; and the upper Koyukuk area, which includes that part of the Koyukuk Valley lying north and northeast of Bettles and the country near Wiseman. Much the larger part of the present placer production from the Koyukuk district now comes from the upper Koyukuk and Hughes areas. In the northern Koyukuk area mining was much hampered by the extreme dryness of the season. In fact, many of the streams were at such low stages that great difficulty was experienced in getting supplies of food upstream as far as Alatna. The most gold came from placers in the immediate vicinity of Wiseman, including those on Nolan and Archibald Creeks, but there were nearly 20 camps on many of the streams that were much more remote. For example, there were 3 camps on Hammond River, 2 on tributaries of Bettles River, 5 on tributaries to Middle Fork from Tramway Bar to Slate Creek, 3 on tributaries of Wild River, and 1 on Alatna River, exclusive of a few individual prospectors who did not report their work to the Geological Survey. It is understood that extensive equipment was already en route, before navigation closed, to mechanize one of the mining properties on Myrtle Creek that had been acquired recently by Schwaesdall \& Repo. It is believed that this will be the first attempt to put an efficient modern plant in this area, and when it is in operation it will probably be the most northern plant of its kind in Alaska.

In the Hughes-Indian River area of the Koyukuk Valley, the principal producing camp, and indeed the most productive of any in the Koyukuk district, was that of L. McGee, on Utopia Creek, one of the headwater tributaries of Indian River. This company is opening up two more or less separate tracts of ground at this place. The main camp, near the mouth of the creek, is equipped with a $1 \frac{1}{2}$-yard dragline and the necessary accessories for carrying on the work. :Some of the ground handled is said to be as much as 25 feet deep. About 4 miles upstream from this lower camp are the upper claims, which are being mined by hydraulicking. Work at these upper diggings was discontinued toward the end of August because of the shortage of water. Altogether, about 30 men are employed by this company. 
Although, so far as the Geological Survey is informed, there was no mining of placer gold in the Hogatza area during 1939, there was a very significant move under way to prospect part of that area. This work was being undertaken by the Fairbanks Exploration Department, which had a drill crew in the area during most of the open season and proposed to continue its examinations until it was satisfied as to the resources. No announcement has yet been made as to results of the work so far, but it has already attracted much. attention to this area, which has long been untouched.

Reports from the Rampart district indicate that the old camp. showed a greater increase in placer production than it has had in recent years. A large part of the increase is to be attributed to the increased use of mechanical equipment to replace hand labor or dependence on an abundance of water. The largest production from the district came from the property of Minook, Ltd., on Little Minook Creek. Digging is done with a $1 / 2$-yard power shovel aided by a heavy-duty bulldozer, and transportation from the shovel to the sluices is effected by two 4-yard motor trucks. Other operators reporting to the Geological Survey include 3 producers on Hunter Creek and one each on Little Minook and Florida Creeks. In the Troublesome. Creek area, which lies some distance east of the main Rampart district, oneoperator reports having done some mining on Quail Creek. In addition to the mines and prospects noted above, there were doubtless: a few others at widely scattered points in the district who did not report their season's activities to the Geological Survey.

The few reports of the season's activities in the Chisana district that have been received by the Geological Survey direct from the operators indicate that mining there was carried on during 1939 at very nearly- the same places but at a somewhat lower rate than in thepreceding year. As in the recent past, the principal camp in the district is that of the Nelson Mining Co., on Bonanza Creek, but there were smaller camps on that stream as well as on Little and Big Eldorado Creeks and Gold Run, a tributary of Glacier Creek. Probably not more than 20 men were mining in the district, and all of them used simple hydraulic or hand methods. As the district is: one of the less accessible Alaska placer areas it attracts the casual seeker for gold less than many of the more easily reached parts of the Territory.

The placer-gold production in the Eagle district for 1939, which came from essentially the same general area as in 1938, is estimated to have been worth $\$ 3,000$ less than the production for the preceding year. No notable new events were reported. About a dozen small camps were mining on different creeks in the district, but none of them employed more than five men, and many of them consisted 
of a single operator. The largest enterprise was that under the management of Casper Ellingen, on Fourth of July Creek, which joins the Yukon some 30 miles northwest of Eagle. The second most productive area in the Eagle district was the valley of the Seventymile River, where there were a number of camps not only along the main river but also in the valleys of its tributary streams, in Lucky Gulch and Fox, Crooked, Falls, Barney, and Alder Creeks. Smaller amounts of gold were recovered from placers in the valleys of American and Wolf Creeks.

In the past it has been the practice in these reports on the mineral industry of Alaska to include the production of the Chandalar district with that of the Koyukuk, because of the few operators in the Chandalar district. In recent years, however, placer production from this district increased to the point where that practice was no longer necessary. It is evident, however, that at best only a negligible amount of placer mining is in progress in this entire district and that even the largest of the camps consist of but one or two workers in addition to the owner. So far as the Geological Survey is informed, three outfits produced some placer gold in the Chandalar district in 1939. Two of these were on Big Creek, and the other was on Little Squaw Creek, a tributary of Lake Creek. Prospecting was in progress on Tobin Creek, but it is reported to have amounted to little more than groundsluicing off the overburden from some of the ground that will be mined later.

North of the Yukon River, in a rather indefinite tract that extends some 30 miles both to the east and to west of the settlement of Tanana, at the junction of the Tanana and Yukon Rivers, is a large area in which placer mining has been in progress from time to time at scattered camps. This tract for convenience has been called in these reports the Fort Gibbon district. In 1938 there were several camps in the district that were active mines and that in the aggregate produced placer gold to the value of $\$ 16,000$. Since then mining has dwindled until in 1939 there were so few operators that to disclose their production would have been contrary to the Geological Survey's policy of not publishing statistics that would reveal individual operations. Consequently in the table on p. 39 the production from this district has not been listed separately but has been merged with the records from other nearby areas. In this connection it may be said that in so doing the totals for the other districts to which these figures have been added have not been appreciably affected by this consolidation.

KUSKOKWIM REGTON

Included in the Kuskokwim region are four principal districts where gold placers were mined in 1939. For convenience of description they 
are here called the Mount McKinley, Georgetown, Tuluksak-Aniak, and Gooknews districts. 'The Mount. McKinley district, as the term is here used, embraces all the eastern part of the Kuskokwim Valley, but the placer mining in it is more or less localized around McGrath, Takotna, and Medfra. The Georgetown district is in the central part of the Kuskokwim Valley, and the settlement of Georgetown, on the Kuskokwim, about 45 miles in an air line south of Iditarod, is situated near the center of the southern border of the district. Although lying in the Kuskokwim drainage basin, the district actually has closer affiliation with the Iditarod district, to which it has better transportation facilities than to many of the Kuskokwim points. The Tuluksak-Aniak district is named from two rivers that traverse parts of it; the Tuluksak enters the Kuskokwim from the south some distance east of the settlement of Bethel, and the Aniak enters the Kuskokwim about 50 miles still farther upstream, to the east. Goodnews district takes its name from Goodnews Bay, a small indentation of the coast on the east side of Kuskokwim Bay, about 125 miles in an air line south of Bethel.

The production of placer gold in the Kuskokwim region in 1939 is estimated at $\$ 1,283,000$. This is nearly 60 percent more than the placer gold produced from the deposits in 1938.' In view of the enormous area included in the Kuskokwim region, the amount of the present production. is extremely small, but when it is remembered that there are probably less than 150 white miners in the whole region, that their activities are much handicapped by their remoteness from supplies, and that their expenses are consequently large and their funds small, the wonder is that the production is so much. From such geologic iniformation as is available regarding the Kuiskokwim region, it seems certain that there are areas in this region that well deserve more intensive investigation and that there is a fair probability that close examination and intelligent prospecting in the vast, totally unexplored areas that fall within its confines might disclose not only workable gold placers but also other valuable mineral deposits.

In the Mount McKinley district, as in the past, there were three main areas in which placer mining was in progress. These are the Moore Creek area, the Candle Creek area, and the Medfra area. The Moore Creek area lies some 50 miles southwest of McGrath and is near the head of Takotna River. At this place the largest placer camp is that of the Moore Creek Mining Co. This company is mining with a dragline and bulldozers, and, though details are lacking in the Geological Survey as to the results of the year's work, general information indicates that the company had an especially good season, though it was somewhat delayed at the beginning of the season by the slow disappearance of the preceding winter's snow. 
This handicap probably proved an advantage later, for as the snow melted it must have kept the water supply at a better stage than normal. Some development work was in progress on Willow Creek.

The second area in the Mount McKinley district includes Candle Creek, which is a tributary of the Takotna River, lying just west of McGrath. There has long been a small amount of placer mining in the valley of Candle Creek, and at one time a small dredge was used for mining the deposits in the eastern part of this valley. Late in 1937 and continuing through 1938 and 1939 a large tract adjacent to the old dredge has been mined with a dragline. About 25 men are employed on these claims under the general and direct management. of the Strandbergs. Judging from the amount of gold recovered, the results of the year's work must have been highly satisfactory.

The third area in the Mount McKinley district lies some 30 miles northeast of McGrath. The placer areas seem to center more or less around the flanks of the Nixon Fork Mountains, in which workable gold lodes have been discovered. No extensive placer deposits have been opened up in the area, and such placer mining as has been done has been carried on by one- or two-man camps. The principal stream on which there was placer mining in 1939 was Holmes Gulch, a small headwater tributary from the north to Hidden Creek.

Productive placer mining in the Georgetown district in 1939 appears to have been restricted to Donlin and Julian Creeks. Donlin Creek is a tributary of Crooked Creek, which joins the Kuskokwim a short distance downstream from Georgetown, and Julian Creek is a tributary of George River, which flows into the Kuskokwim immediately east of Georgetown. The mineralized areas on these streams lie only about 25 to 40 miles south and southeast of the town of Flat, in the Iditarod district, and as they are reached most easily from that district they might really be considered as outliers of the Iditarod deposits. They are about 25 miles in an air line northwest and northeast of Georgetown, on the Kuskokwim. No details have been received by the Geological Survey as to the season's accomplishments in either of these areas. From the lack of information it seems probable that mining was perhaps somewhat less active there than it had been recently and that no important new developments took place during the year.

In the Tuluksak-Aniak district the bulk of the placer gold production came from the property of the New York-Alaska Gold Dredging Co., in the vicinity of Bear Creek. This company operates two dredges, one with 4-foot buckets and the other with $21 / 2$-foot buckets and a dragline, together with the various accessories needed in the successful carrying out of its extensive plans: During 1939, in addi- 
tion to its directly productive work, the company completed its 4-mile ditch from Bear Creek and put into operation its hydroelectric plant on the Tuluksak and will utilize the power thus generated in running its dredges and other electrical equipment. The power plants on the dredges were converted from Diesel-electric to straight electric-driven machines. This new power equipment should greatly lessen the costs of operation from what they were formerly, when much of the gasoline used in the engines was transported by airplane from Bethel, on the Kuskokwim River, or had to be brought in by the much longer, circuitous overland route. The demonstrated success of this company and the value and extent of its holdings are encouraging it to consider seriously undertaking an even more extended program in this district in the future, and it is understood that the addition of another and larger dredge to its fleet is even now in contemplation.

In addition to the dredging operations on Bear Creek, there were several smaller mines in the general neighborhood. The largest of these seems to have been that of the Garrison Co., on Granite Creek, a tributary of Tuluksak River from the north. Some 10 miles or so south of Bear Creek is Marvel Dome, a prominent landmark on the highland that forms the divide between the eastward-flowing streams that ultimately join the Aniak River and the westward-flowing streams that, like the Tuluksak, join the Kuskokwim not far from Akiak or Bethel. A number of the streams that flow outward from Marvel Dome have placer deposits in their valleys, and several small mining camps are busy on them each year. .. In 1939 ; the targest $\ldots$ of these, in point of placer gold production, was the Marvel Creek Mining Co., which consists of Henry DuRand, Fritz Awe, and Luther Hess. This company had shipped in a dragline, tractor, bulldozer, and other equipment late in the fall of 1938 and had freighted them to the company's ground during the winter and spring so that they were in shape for use almost as early as they could be used in production mining. The success of the operation seems demonstrated by the amount of gold recovered. Marvel Creek is a tributary of Salmon River, which flows northward and eastward into the Aniak River, and that stream in turn joins the Kuskokwim about 75 miles in an air line northeast of Akiak. Another of the placer camps in the neighborhood of Marvel Dome was that of Kvamme \& Co., on Canyon Creek, under the management of Alfred Anderson. Canyon Creek is a small tributary of the Kwethluk River, which joins the Kuskokwim a short distance west of the settlement of Akiak. Several other small outfits of a few men each are reported to have been carrying on some mining in this same general area, but details regarding their work have not been furnished the Geological Survey, and apparently the total amount of gold they recovered was small. 
For some time after the discovery of the placer-platinum deposits of the Goodnews district, interest in the gold placers waned and almost ceased. Within the last 2 years, however, there has been a great revival in the search for gold placers and the development of those that appeared attractive. Perhaps the item of most significance in the development of gold placers in the district in 1939 was the highly successful season experienced by the Bristol Bay Mining Co. at its properties on Wattamuse Creek. This ground is being mined by a dredge that was built during 1938 . Unfortunately, soon after starting work in that year the dredge was badly damaged so that 1939 really was the first full season it was in productive operation. The second largest amount of placer-gold mining in the district in 1939 appears to have been done by the Goodnews Bay Mining Co. at its property on Snow Gulch, a small tributary to the East Fork of Arolic River. The mining of this placer is being done by a combination of hydraulic and dragline methods. On Kowkow Creek, which is also a tributary to Arolic River, the Kow Kow Mining Co. is mining with a dragline. Another stream in this same watershed on which mining was done is Butte Creek. Mining here is under the management of John Huff, who with a crew of 6 men is using a bulldozer in connection with hydraulicking. At this property part of the open season was lost for productive mining, owing to the need of constructing a 3 -mile ditch to bring water in from Trail Creek. Until the ground had settled, considerable trouble was experienced with the ditch holding, but by the end of the season this no longer was serious.

SEWARD PENINSULA

The production of placer gold from Seward Peninsula in 1939, including the production from northwestern Alaska, is estimated at $\$ 3,600,000$, or about $\$ 113,000$ more than in 1938 , itself a year of especially large production. The increase does not appear to have been made through unusually favorable conditions, and this portends well for the maintenance of the present rate of production for some time. In fact, to judge from the increased mining activity throughout the peninsula and the additional equipment being installed at many of the properties to replace the less effective and more costly manual labor that had hitherto been employed, it would seem entirely reasonable to expect that further increase in production is inevitable.

A large part of the gold recovered from Seward Peninsula placers is mined by dredges. In 1939 gold worth $\$ 2,922,000$, or slightly more than 81 percent of the placer output of the peninsula and northwestern Alaska, was mined by 21 dredges, one or more of which was active in practically every one of the larger districts of the peninsula. 
Additional data regarding dredge mining in this and other parts of Alaska are given on pages $68-72$.

In the relative order of their output of placer gold in 1939 the mining districts of Seward Peninsula stood as follows: Nome, Kougarok, Fairhaven (including Candle, Inmachuk, and Bear Creek areas), Council, Koyuk (including the areas adjacent to and east of the head of Norton Sound), Port Clarence, Solomon (including the Casadepaga River area), and Bluff. So much of the placer gold from some of these districts came from only one or two mines that it has not seemed advisable to publish estimates of the production of the separate districts, as it might disclose the output of individuals.

The outstanding placer enterprise in the Nome district, as well as in the whole of Seward Peninsula, and the second largest in the Territory continues to be that of the United States Smelting, Refining \& Mining Co., Nome Department. This company is operating three dredges in the valley of the Snake River and its tributaries, near Nome, and has extensive ditches, some of which are more than 20 miles long, and other equipment for properly conducting its work. Some notes on the operation of these dredges are given on page 70. The work of this company involves the dredging of extensive tracts of the coastal plain adjacent to Nome, in which ancient beaches occur at intervals inland from the present beach to the foot of the rock hills that rise steeply some 3 miles or more from the shores of Norton Sound. Much of the area to be mined is permanently frozen, so that considerable preparatory work has to be done in stripping and thawing it before it can be successfully mined by the company's dredges. All the various steps must therefore be carefully planned and coordinated, so that they progress in orderly fáshion without interference and at all times provide sufficient ground ahead of the dredges for uninterrupted work. Power for the operation of the dredges, as.well as for the many other purposes for which it is needed, is provided by the generation of electricity at a central plant through the use of fuel oil that is shipped in by tankers from the States. The large amounts of water used in the thawing operations, as well as for other purposes, are mainly supplied by long ditches, some of which have their intake far up in the hills to the north of Nome. These supplies, however, are supplemented by power pumps utilizing nearer sources of water. The high engineering efficiency and smooth running of this complex undertaking give abundant proof of the ability of the staff who outlined the plans and of the personnel who are so ably carrying them out. Approximately 250 men were employed in various phases of the company's work.

Three other dredging companies were operating the Nome district in the season of 1939-the Alaska Sunset Mines Co., on Sunset Creek; the Casa De Paga Gold Co., on Monument Creek, a tributary of Snake 
River; and the Osborne Dredging Co., near the junction of St. Michael and Osborn Creeks. The Sunset dredge was mining in the coastal plain area some 7 miles west of Nome. Mining at this place in 1939 was at a somewhat reduced rate as compared with that of the preceding year, and work was suspended rather earlier than usual in the fall. The Casa De Paga Gold Co.'s dredge was working all of the season on Monument Creek, a tributary of Snake River from the west. This work is regarded by the operators as practically finishing up all the dredging ground for their boat in the neighborhood, and the dredge is to be moved to a new site on Beaver Creek in time to be ready for the season of 1940. Beaver Creek is one of the streams tributary to Eldorado River, a large stream situated about midway between Nome and Solomon Rivers. Developments at this place will be watched with special interest, as heretofore in this part of the area no productive placers have been developed. The property of the Osborne Dredging Co. is situated on Osborne Creek, some 10 miles northeast of Nome. In 1939 its work was a continuation of that which has been in progress there for several years, though during that time the company has been reorganized and its name changed from the Greenstone Mines, Inc.

In addition to the dredges there were a number of open-cut and hydraulic mines on many of the creeks in the Nome district. No exact count was obtained as to the number of these properties, but apparently within a radius of 20 miles or so of Nome there were at least a score that were active during the season. Some of these, it is true, consisted of only a single miner or a miner and his partner, and many of them were mining during only part of the season and their output was but a modest grubstake. In the aggregate, however, these smaller mines produced more gold than some of the dredges. Among the larger of the mines using other methods of mining than dredging, may be mentioned the property of Ben F. Gillette, on the eastern slopes of Anvil Creek Valley, near Specimen Gulch. The ground is mined by hydraulicking and seems to represent one of the old highlevel channels of Anvil Creek. Search for the other channels of this sort was in progress at several other claims in the same general neighborhood.

The Kougarok district, as that term is used in this report, includes much of the central part of Seward Peninsula, being very vaguely delimited on the south by the Nome district, on the west by the Port Clarence district, on the north by the Inmachuk area of the Fairhaven district, and on the east by the Casadepaga area of the Solomon district. Recently, with the improved methods of mining by mechanized equipment, mining in the district has shown a great increase and does not yet appear to have. reached the expansion of which it is capable. There are two principal centers around which the most 
active work has been in progress. These are a northern area lying near the head of the Kougarok and embracing not only the main stream and its tributaries but even Dick Creek, which lies north of Kougarok River, and a southern area, which includes the country near Coffee Dome and stretches of the southern part of the Kougarok Valley. In addition there are a number of widely scattered camps throughout the district that in the aggregate yield considerable placer gold. Among these outlying areas may be included the Iron Creek area, which might perhaps be considered as an outlier of the Nome district, and the scattered camps on streams tributary to Noxapaga River, such as Buzzard, Goose, and Black Gulches. A large amount of gold that came from the Kougarok district was mined by the dredges of the Fox Bar Dredging Co., in the southern part of the Kougarok Valley, and of the Kougarok Consolidated Placers, Inc., near the head of that valley. The season's work at both these dredges seems to have resulted in a larger output of gold than heretofore. In the Iron Creek area a new dredge was erected during 1939 on claim No. 10 below, on Iron Creek, by Tolbert Scott. A new hull and superstructure were built, and machinery that formerly was used in a dredge on Arctic Creek in the Port Clarence district was installed. The bucket line is driven by a Diesel engine and has $2 \frac{1}{2}$ foot open connected buckets. So much of the open season was spent in assembling this dredge and in getting under way that it was productively mining only a short time. It should, however, have been well broken in, so that it may be in good running order for 1940. It is understood that parts for a new dredge to be built for mining on American Creek near Game Creek and Auburn Ravine, were freighted in to the property during the year and that the assembly of them had practically been completed, although not in time for the dredge to be used in 1939. It is, however, unwarranted to stress the activity indredging as the principal reason for the increase in mining activity in the Kougarok district. In fact, fully as much gold came from camps having other mining methods. These camps ranged from those with elaborate mechanical equipment and yielding tens of thousands of dollars worth of gold to camps in which a lone worker employed only crude hand methods. Among some of the larger producers using other than dredging methods may be mentioned Keenan \& Castleton, the Alaska Taylor Mining Corporation, Kougarok Consolidated Placers (dragline and hydraulic plants), and Mascot Mining Co., on Kougarok River; the Dahl Creek Mining Co., George Waldhelm, and Louis Nashenweng, on Dahl Creek; Bodis and associates, on Dick Creek; Lammers-Fitzpatrick Mining \& Exploration Co., on Buzzard Creek; and Barney Rolando, on Gem Creek.

277199-41- -5 
The placer gold mined in the Fairhaven district comes from three main tracts-near Candle, the Inmachuk River, and Bear Creek. Altogether more than 200 men were employed on different mining properties in this district in 1939. Candle Creek is a large tributary of the Kiwalik River from the West, close to the town of Candle. The principal mining operation in this part of the district is that of the Arctic Circle Exploration, Inc. This company has control of extensive tracts along Candle Creek, which include not only the lowlands along. the creek but also bench gravel high on the valley slopes. The different types of deposits necessarily must be mined by different methods, so that both dredging and hydraulicking are resorted to, and an extensive mechanical equipment is utilized. For the part that can be dredged, two dredges were used. The older of these was mining on claims Nos. 3 and 4 below, on Candle Creek, not far from the settlement of Candle, and the newer dredge, which was built in 1937, was on claims Nos. 16 and 17, above Candle Creek. Both dredges were somewhat handicapped during the early part of the season by being delayed while the ground ahead of them was being thawed. After this condition had been taken care of the dredges appear to have had an especially good season. In addition to production from its dredges, the company derives nearly a quarter of its output of placer gold from ground that is mined by hydraulicking and by the use of a dragiine and tractors. Most of the placer that is mined by the company by methods other than dredging is bench ground on claims Nos. 13-15, $3 \mathrm{~d}$ tier, on the western slopes of Candle Creek.

A few small one- and two-man camps were also established on. creeks adjacent to Candle. Of these may be mentioned those on Jump and Patterson Creeks. Farther south of Candle, on Quartz: Creek, which joins the Kiwalik River from the east, productive placer mining was done, and on Gold Run, which enters the Kiwalik River" from the west a few miles below Quartz Creek, some prospecting was: in progress. No details have been furnished the Geological Survey as to new developments in these smaller camps during the year, and in the absence of such information it is assumed that such work as was done disclosed no noteworthy new conditions. A project involving the drilling of a large tract of placer ground on Kugruk: River was carried out during 1939. The results are said to have disclosed a large tract of placer ground carrying sufficiently high: concentrations of gold to encourage the development as soon as. practicable.

In the Inmachuk Valley, which lies some 30 to 40 miles west of Candle, one of the principal producers was the Forsgren Dredging Co., which is mining with a small dredge some distance southwest of the settlement of Deering. The production of placer gold by: 
the dredge indicates that the company had an especially good season, though details as to the specific accomplishments are not available to the Geological Survey. During 1939 most of the dredging was on the ground near the mouth of the Pinnell River. Several small hydraulic or open-cut plants were established at other points in the valleys of the main stream or of its tributaries. The largest of these was the hydraulic plant of David Hoogendorn, on Discovery Gulch, which employed five men. During 1939 the dredge of the Dry Creek Mining Co., which had been active for many years in the coastal plain area, immediately north of Nome, and which had been dismantled and moved to a new site on Inmachuk River, was rebuilt. This work occupied practically the whole of the open season, so that it was not one of the active dredges during that year. However, the reassembling and reconditioning of the dredge was completed before the season closed, so that it should be ready for an early start in 1940 .

The third tract in which placers were mined in the Fairhaven district includes Bear Creek and adjacent areas on the eastern flank of hills that form the divide between the Buckland and Kiwalik Rivers. No reports as to recent mining developments in this area have been received by the Geological Survey, and it seems probable from their absence that the activity in the area was small and that presumably the placer-gold production from it was about the same as or less than in 1938. Even during the periods when the area is fairly active there are rarely more than three or four camps mining in it, and their gross production is usually valued at only a few thousand dollars.

The records received by the Geological Survey from the Council district in 1939 indicate that it was fourth among the districts of Seward Peninsula in point of its placer production and that it had somewhat increased the amount of placer gold that came from its mines. As usual, by far the greater part of the production came from the four dredges that were active in the district. Of these dredges, two were the property of the Council Dredging Co., which was working in the flood-plain deposits of the Niukluk River at and above the valley of Ophir Creek; the Alaska Placers Co. was operating in the flats of Niukluk River with the dredge formerly owned by the North Star Dredging Co.; and the Inland Dredging Co. was mining on Aggie Creek, a tributary of Fish River. The dredge of the Inland Dredging Co. was not completed until late in 1938, so that the season of 1939 was the first in which it received a thorough try-out. The second dredge of the Council Dredging Co. was a new dredge that the company had placed in commission in the flats of the Niukluk River, near the mouth of Camp Creek. The Alaska 
Placers Co. was a newly organized company, which had acquired the dredge and other property of the former North Star Dredging Co. The principal owners of the new company are the Lucas brothers. After the purchase of the property the new company made some alterations in the dredge, the most extensive one being the substitution of a close-connected bucket line for the former openconnected one.

The Koyuk district, as that term is used in this report, embraces all of southeastern Seward Peninsula as well as the adjacent region immediately east of Norton Bay. In this large tract are two more or less definite centers around which the present placer mines are situated. The northern center has for its focus the settlement of Haycock, on Dime Creek. The southern may be briefly referred to as the Ungalik area. The placer production from the Koyuk district in 1939 showed still further increase over the high record set in 1938. This was largely brought about by the successful operation of the dredge of the Ungalik Syndicate on Ungalik River and Bonanza Creek. From 13 to 33 men were employed at various times at this mine, not so much for the operation of the dredge as for thawing frozen ground, drilling to test areas ahead of the dredge, and performing other duties incident to the general maintenance of operations. Mining was not started at this camp until July 2. In addition to this large dredge, a smaller one farther down Ungalik River, owned by Frank Shaw, has done some dredging. Many difficulties have been experienced with this dredge, and so far as could be learned it was not used in productive mining in 1939, though some work was done to put it in condition. In the northern part of the Koyuk district there was another dredge, that of the Dime Creek Mining Co., on Dime Creek. This is a small dredge that has long been operating in this neighborhood, and it has produced a small but consistent amount of placer gold. Dredging by the Dime Creek Dredging Co. was at about the same place in the area north of Haycock as for several years past. Almost all of the placer mining in the Koyuk district that was done by methods other than dredging was in the Haycock area. Altogether in this part of the district there were, in addition to the dredge, two or three drift mines that were operated during the winter and several open-cut mines that were worked during the summer. The total number of men employed in productive mining is estimated to have been between 30 and 35. All the drift mines and most of the open-cut mines were on Dime Creek, but two open-cut mines were on Sweepstake Creek, a few miles to the west.

The production of gold from placer mines in the Port Clarence district in 1939 was somewhat greater than in 1938. This was rather 
unexpected, because the season there was late in opening in the spring and closed unusually early in the fall. A large part of the placer gold is mined by the dredge of the Bartholomae Oil Corporation on Gold Run, a tributary of Bluestone River, some 12 miles south of Teller. In order to get as early a start as possible, it was necessary to use artificial thawing at places ahead of the dredge and to continue this practice even later in the season to remove outjutting points of frozen ground. On the whole, however, the material mined lies in the channel of the creek, so that it is thawed naturally. The owners report a considerably larger percentage of fine gold in: their clean-ups than in the preceding years. They do not attribute the condition to an actual change in the content of the ground but believe it is due to the improved facilities used for catching and recovering the finer particles of gold in the clean-up. For several years a small dredge, belonging to $\mathrm{N}$. B. Tweet \& Sons, mined intermittently on Dese Creek, some 6 to 8 miles east of Teller. This dredge appears to have been idle throughout 1939, but its owners were mining on Coyote Creek, in the same general neighborhood, by the combined use of a bulldozer and hydraulic methods. A few small open-cut and hydraulic mines are also in operation in the district for part of the season. The largest of these appear to have been that of Martinson and associates, near the head of Gold Run, and camps on Offield and Sunset Creeks. Some drilling and exploration work was done to test a considerable tract of country in the valleys of Budd and Joe Creeks, which are tributaries of Agiapuk River, north of Teller, and Imuruk Basin.

In the Solomon district by far the greater part of the placer gold produced in 1939 came from the dredge of the Lee Bros:, on the Solomon River, some 6 to 8 miles above the mouth of that stream. At this place a well-equipped surface plant, with all modern conveniences including an air field, has been established. The dredge is one that has long been used on the Solomon River, but it has been modernized and well-equipped by its present owners, so that it has made an especially good showing. So successful has been; this enterprise in the last three seasons that the company has generally enlarged its holdings in the valley of Solomon River and adjacent areas and during 1939 shipped in materials and parts for a new dredge. Delays in getting the material shipped and transported to the assembly site and then getting the dredge built consumed so much of the open season that the operators were unable to use the dredge for productive mining in 1939. It should, however, be in condition to be started early in 1940 and should perform effectively. Some open-cut mining by small outfits was also in progress in various parts of the valleys of these two main streams. None of them, however, employed more than two or three men, and many of them were mere individual 
workers. The aggregate production from all this simpler type of mining probably did not exceed a few thousand dollars, and few of the miners made more than a modest grubstake.

In the Bluff district there were more mining camps active than in any of the immediately preceding years, and a great variety of mining methods were employed at the various camps. One of the most unique mining projects in this district, or perhaps in the whole of Alaska, is that of the Topkok Chief Mining Co., near the mouth of Daniels Creek: The notable feature of this plant is that it is essentially a scraper outfit set up on the sea ice off the coast in the winter. The scraper operates through a trench kept open in the ice to excavate the placer material on the sea floor and bring it inland, where it is heaped into a stock pile that is sluiced up during the summer, after the offshore work has had to be discontinued owing to the sea ice having moved away. This company also has claims inland on Daniels Creek, which it mines during the open season with a slack-line scraper. During 1939 one of the old dredges that had lain idle for some time in the Nome district was acquired and moved to California Creek in the Bluff district. This dredge, under the management of Mahan \& Slack, was in operation only a little more than a month, owing to delays incident to the installation of a new Diesel engine and the very late date of the break-up in the spring. On Swede Creek the Swede Creek Mining Co. mined with two slake-line scrapers and derived its necessary supply of water mainly by pumping it from the sea to an elevation of about 140 feet. The present installation is regarded by the company as inadequate, and it proposes to replace them next year with a gas shovel and trucks. There were also a few small one- or two-man camps using simple hydraulic or hand methods of mining on several of the creeks in the Bluff district, but apparently the result of their work was the production of only a small amount of placer gold.

\section{NORTHWESTEKN ALASKA}

The Kobuk River Valley is the only area in northwestern Alaska that is reported to have been the scene of any placer mining in 1939. In this valley there are two principal areas where placer mining is being done. 'The western area is near Kiana, and the principal placer tract is in the valley of the Squirrel River and especially in the valley of its tributary, Klery Creek. The eastern area is in the vicinity of Shungnak, a small settlement about midway between the head and mouth of the Kobuk River. Kiana is about 50 miles in an air line above the mouth of Kobuls, and Shungnak is about 90 to 100 miles in an air line east of Kiana. Both of these tracts are so remote and so poorly served by any regular means of transporta- 
tion or communication that their development is much retarded and hampered by high costs, unavoidable delays, and a short working season.

So large a part of the production of placer gold from northwestern Alaska came from one mine that it has not been consdered desirable to list the report from the region separately, as to do so would divulge the individual output. As a consequence, the production of placer gold for northwestern Alaska has been consolidated with that from Seward Peninsula in the table on page 32.

In the Kiana area the principal operator is the Klery Placers, Inc, whose main holdings are claims in the valley of Klery Creek and some of the adjacent beach ground. Mining at this place is done with a dragline equipment and accessory bulldozers, tractors, and hydraulic plant. No specific report as to the work of the company in 1939 has been furnished the Geological Survey, but from general sources of information the company appears to have had an especially satisfactory season. If this is true, it probably reflects the result of the extensive improvements effected during 1938, whereby an extensive system was built to supply water under head for all phases of the mining work. Although in one of the most remote parts of Alaska, the mine has been made relatively accessible for air service from Kotzebue through the construction of a nearby landing field.

In the tract near Shungnak the placer deposits occur in the lowland adjacent to the Kobuk, close to the places where the small streams that come down from the hills to the north traverse that lowland, or in the valleys of the streams within this belt of hills. The source of the placer gold found in these deposits appears to be local, as in general the gold is rough and shows little evidence of having been transported far. This conclusion is further supported by the occurrence of many quartz veins carrying free gold in the metamorphic rocks that form the hills in which these streams rise or which they traverse. In 1939 several small camps, some of which accomplished little more than panning tests, employed a total of about 12 to $15 \mathrm{men}$, some of whom were natives, on streams in the vicinity of Shungnak. Of these camps three were on Dahl Creek, two on the Shungnak River, and one each on Boulder, Riley, and Lynx Creeks. Lynx, Riley, and Boulder Creeks are tributaries of the Kogoluktuk River, which joins the Kobuk some 3 or 4 miles east of Shungnak, and the Shungnak River enters the Kobuk about 15 miles. west of Shungnak. Reports from this area indicate that 1939 was a very poor year for mining there, because during much of the open season the miners were hampered by too much water, and the freeze-up in the fall came almost a month ahead of the usual time and thus seriously curtailed the working season. 
Slightly more than 66 percent of all the placer gold produced in Alaska in 1939 was mined by dredges. The total value of the gold thus recovered was $\$ 10,677,000$, of which the greater part came from 19 dredges in the Yukon region and the rest from 21 dredges in Seward Peninsula and three in the Kuskokwim region. This total, which is more than 8 percent greater than the value of the gold recovered by dredges in 1938, represents increases of about $\$ 831,600$ in value and 23,760 fine ounces in quantity. The accompanying table gives the value of the gold output and the yardage handled by Alaska dredges from the earliest year for which records are available to the end of 1939 .

Gold produced by dredge mining in Alaska, 1903-39

\begin{tabular}{|c|c|c|c|c|}
\hline Year & $\begin{array}{l}\text { Number } \\
\text { of dredges } \\
\text { operated }\end{array}$ & $\begin{array}{c}\text { Value of gold } \\
\text { output }\end{array}$ & $\begin{array}{c}\text { Gravel } \\
\text { handled } \\
\text { (cubic yards) }\end{array}$ & $\begin{array}{l}\text { Value of } \\
\text { gold recov- } \\
\text { ered per } \\
\text { cubic yard } \\
\text { (cents) }\end{array}$ \\
\hline $\begin{array}{l}1903 \\
1916\end{array}$ & $\begin{array}{l}34 \\
36 \\
28 \\
28 \\
22 \\
24 \\
23 \\
25 \\
27 \\
27 \\
32 \\
28 \\
27 \\
30 \\
27 \\
28 \\
25 \\
25 \\
30 \\
37 \\
39 \\
41 \\
44 \\
43\end{array}$ & $\begin{array}{r}\$ 12,431,000 \\
2,679,000 \\
2,500,000 \\
1,425,000 \\
1,360,000 \\
1,129,932 \\
1,582,520 \\
1,767,753 \\
1,848,596 \\
1,563,361 \\
1,572,312 \\
2,291,000 \\
1,740,000 \\
2,185,000 \\
2,932,000 \\
3,912,600 \\
3,749,000 \\
4,293,000 \\
4,146,000 \\
6,725,000 \\
7,701,000 \\
8,905,000 \\
8,743,000 \\
9,845,400 \\
10,677,000\end{array}$ & $\begin{array}{r}3,900,000 \\
3,700,000 \\
2,490,000 \\
1,760,000 \\
1,633,861 \\
2,799,519 \\
3,186,343 \\
4,645,053 \\
4,342,667 \\
3,144,624 \\
5,730,000 \\
6,084,000 \\
6,371,000 \\
8,709,000 \\
9,906,000 \\
10,214,000 \\
10,310,700 \\
8,889,000 \\
10,445,000 \\
12,930,000 \\
14,632,000 \\
16,684,000 \\
20,052,000 \\
19,860,000\end{array}$ & $\begin{array}{l}69 . \\
68 \\
57 \\
77 \\
69 \\
57 \\
55 \\
40 \\
36 \\
50 \\
40 \\
29 \\
34 \\
33.6 \\
39.5 \\
36.7 \\
41.6 \\
46.6 \\
64.4 \\
59.6 \\
60.9 \\
52.4 \\
49.1 \\
53.8\end{array}$ \\
\hline Total & - & $107,698,400$ & $192,419,000$ & 49.5 \\
\hline
\end{tabular}

The total value of the gold produced by dredges since 1903 is nearly 31 percent of the total value of gold produced from all kinds of placer mining since 1880, and in some of the recent years the value of the gold recovered by dredging has been as high as 80 percent of the total placer production. In 1939 the percentage of gold recovered by dredging, as already stated, was 66 percent, or essentially the same as for 1938 .

${ }^{7}$ Records regarding the dredge operating in 1939 in the Kuskokwim region to mine principally the placer platinum deposits are not included in any! of the statements given in this section of the report. 
The fact that for the past 2 or 3 years the proportion of gold recovered by the dredges has tended to decrease with respect to the amount recovered by other placer mining methods is due not to an actual decrease in dredging but to the great growth in mining by other methods. This is clearly shown by the foregoing statements and the accompanying table, from which it will be seen that although the percentage of gold recovered by dredging in 1938 and 1939 was about identical the actual value of the gold from this source in 1939 was approximately $\$ 832,000$ more than in 1938 . The extensive use of relatively mobile lower-priced mechanized equipment, such as dragline scrapers and bulldozers, is obviously far more expedient at many of the placer properties suitable for such kinds of equipment than the installation of dredges, which cost more initially and therefore require a longer assured life of the property on which they are to be used, especially if the physical characters of the deposits do not lend themselves well to dredge mining. It seems certain, however, that whether or not the percentage of gold recovered by dredges increases or decreases with respect to the total output of placer gold, there will be in the near future little diminution in the quantity of gold that annually comes from this type of mining. Indeed, all signs seem to indicate that for a number of years an increase in the quantity of gold recovered by dredging is to be expected.

In the foregoing table the figures given for yardage mined and value of the gold recovered per cubic yard are subject to some inaccuracy, because several of the dredge operators have not furnished specific information on those subjects for their individual properties, and the figures for these properties have therefore had to be estimated. In making these estimates the following procedure has been adopted to determine the unknown factors: Operators of dredges that produced approximately $\$ 8,749,757$ in gold, or slightly less than 82 percent of the total mined by dredges; report that that amount came from $16,275,772$ cubic yards of gravel. By applying this average to determine the unreported yardage a total of approximately $19,860,000$ cubic yards is obtained, and this is the figure that has been used in the table. This procedure is obviously open to criticism, because the companies that reported fully the amount of gravel mined were the larger ones, and doubtless they worked ground of a lower tenor than that mined by some of the smaller companies. As a result the average value adopted may be too low and consequently may indicate a larger volume of gravel than was actually handled. This method, however, has been followed for the last 15 years, so that the quantities and values given for 1939 were computed on the same basis as those reported for the recent preceding years. In comparing the actual values, however, attention should be called to the fact that, as in all the tables in this 
volume, the price of gold prior to 1934 has been computed at the recognized official figure of $\$ 20.67$ an ounce, whereas after 1933 a price of $\$ 35$ an ounce has been adopted. If the production of gold from dredges in 1939 had been computed at the old standard price the average value per cubic yard would have been practically 31.7 cents a yard, or about 2.7 cents higher than that for 1938, the lowest that heretofore had been recorded since dredging began in the Territory.

The length of time that the different dredging companies operated varied widely. The longest season reported for 1939 was 265 days for dredges of the United States Smelting, Refining \& Mining Co., Fairbanks Department, operating in the Fairbanks district of the YukonTanana region. The longest season reported for any of the Seward Peninsula dredging companies in 1939 was 163 days for the United States Smelting, Refining \& Mining Co., Nome Department, operating in the Nome district. The earliest date for beginning work in the spring of 1939 and the latest date for ending work in the fall were reported by the Fairbanks Department, which began mining March 15 and did not stop its last dredge until December 4. The earliest and latest dates in 1939 on Seward Peninsula were May 28 and November 16 , both reported by the Nome Department. The average length of the season in 1939 of the 22 companies who reported dates of beginning and ending work, irrespective of how many dredges they operated, was 126 days. Obviously the shortness of this average season was due not to climatic conditions but to getting started late or some other purely local cause at the different dredges. The fact that is demonstrated by these dredging records, is that at practically any of the productive placer camps throughout Alaska a moderate-sized dredge, reasonably well handled, may be expected to have an average working season of at least $4 \frac{1}{2}$ months, and that, with skill and special provisions against unfavorable climatic conditions, the season may be considerably extended in practically any of the placer camps south of the Arctic Circle.

The following is a list of the dredges that did some productive mining during 1939:

Yukon region:

Circle district:

Gold Placers, Inc

Coal Creek.

Alluvial Golds, Inc

Woodchonper Creek.

C. J. Berry Dredging Co Mammoth Creek.

Fairbanks district :

$\begin{aligned} & \text { United States Smelting, Refining \& Min- }\left\{\begin{array}{l}\text { Goldstream Greek. } \\ \text { Cleary Creek. } \\ \text { ing Co., Fairbanks Department (6) } \ldots--\end{array}\right. \\ & \text { Deadwood Mining Creek. } \\ & \text { Pedro Creek. }\end{aligned}$


Yukon region-Continued.

Fortymile district:

North American Mines, Inc Wade Creek.

Boundary Dredging Co Canyon Creek.

Hot Springs district:

American Creek Operating $\mathrm{Co}$

American Creek.

Iditarod district:

North American Dredging $\mathrm{Co}$ Otter Creek.

J. E. Riley Investment $\mathrm{Co}$

Do.

Innoko district:

Waino F. Puntila

Little Creek.

Moss \& Larson Mining Co. (formerly

Savage \& Matheson)

Ganes Creek.

Holky Dredging Co

Do.

N. J. Vibe

Yankee Creek.

Kuskokwim region :

Goodnews district:

Bristol Bay Mining $\mathrm{Co}$

Wattamuse Creek.

Tuluksak-Aniak district:

New York-Alaska Gold Dredging Corporation (2)

Bear Creek.

Seward Peninsula region:

Bluff district:

Mahan \& Slack

California Creek.

Council district:

Alaska Placer Co. (formerly North Star

Dredging Co.)

Ophir Creek.

Council Dredging Co. (2) Siukluk River.

Inland Dredging $\mathrm{Co}$ Camp Creek. Àggie Creek.

Fairhaven district:

Arctic Circle Exploration Co. (2) Candle Creek.

Forsgren Dredging $\mathrm{Co}$ Inmachuk River.

Kougarok district:

Fox Bar Dredging $\mathrm{Co}$ Kougarok River.

Kougarok Consolidated Placers, Inc Do.

Tolbert Scott Iron Creek.

Koyuk district:

Dime Creek Dredging $\mathrm{Co}_{-}$ Dime Creek.

Ungalik Syndicate \{Ungalik River. Bonanza Creek.

Nome district:

Alaska Sunset.Mines Co Sunset Creek.

Casa De Paga Gold Co__-_._-_._.-.-. Monument Creek.

Osborne Dredging $\mathrm{Co}_{-}$ Osborne Creek.

United States Smelting, Refining \& Mining Co. (3)

Snake River area.

Port Clarence district:

Bartholomae Oil Corporation. Gold Run.

Solomon district:

Lee Bros. Dredging $\mathrm{Co}_{-}$ Solomon River. 
The dredges that were active in 1938 but not in 1939 were those of the Glass Dredging Co., on Melsing Creek, in the Council district; Shaw \& Cook, on Ungalik River, in the Koyuk district; the Dry Creek Dredging Co., on Dry Creek, in the Nome district; and N. B. Tweet \& Sons, on Dese Creek, in the Port Clarence district.

Three dredges that were not in operation in 1938 were mining in 1939 ; in the Seward Peninsula region, Mahan \& Slack, on California Creek, in the Bluff district; Council Dredging Co., on Camp Creek, in the Council district; and Tolbert Scott, on Iron Creek, in the Kougarok district. One dredge was operated on Nome Creek, in the Fairbanks district in 1939 that had been moved from Deadwood Creek, in the Circle district, where it was in operation in 1938. Of the dredges that were in operation in 1939 but not in 1938, one was newly constructed and two were old dredges that had been acquired by new organizations, moved to new locations, and rebuilt and otherwise reconditioned.

\section{SILVER}

None of the materials that are now being mined in Alaska are valuable solely for the silver they contain, and by far the greater part of the silver that is produced occurs as a relatively minor constituent or byproduct in ores whose principal value lies in some other metal. As is evident from the following table, nearly 70 percent of the silver that has been produced from Alaska in the past has been derived from ores that are valuable mainly for their copper content. How small the percentage of silver is that occurs in these copper ores may be gathered from the fact that it is seldom as much as 2 ounces to the ton of ore, and the average amount recovered has rarely been as much as $1 \frac{1}{2}$ ounces to the ton. For 1939 it is estimated that no silver was derived from distinct copper ores.

All the gold-lode mines yield some silver in addition to their gold. Thus the mine of the Alaska Juneau Gold Mining Co., though worked principally for gold, yielded 111,494 fine ounces of silver in 1939 , according to the company's published report. The extremely small proportion of silver in the ore from this mine is shown by the fact that this quantity of silver came from 2,377,718 tons of rock that was fine-milled; in other words, the quantity of silver recovered was a little less than 0.047 ounce to the ton. The silver from all the gold-lode mines amounted to 128,500 ounces and was worth $\$ 87,100$. Some silver is also contained in all the gold that is recovered from Alaska placer mines. This silver is not recognizable in the crude gold dust or nuggets received from these mines, as it is intimately alloyed with the gold and is recovered only after the gold is treated 
chemically or refined. The total silver from this source was 75,000 ounces, worth $\$ 50,900$.

Data regarding the production of silver have been referred to in several places in the preceding pages and included in some of the tables that cover the production of other metals. For convenience the sources, quantity, and value of the production from each source in 1939, as well as for the earlier years, are set forth in the following table:

Silver produced in Alaska, 1880-1939, by sources

\begin{tabular}{|c|c|c|c|c|c|c|c|c|}
\hline \multirow{2}{*}{ Y'ear } & \multicolumn{2}{|c|}{ Total } & \multicolumn{2}{|c|}{ Copper lodes } & \multicolumn{2}{|c|}{ Gold lodes } & \multicolumn{2}{|c|}{ Gold placers } \\
\hline & Ounces & Value & Ounces & Value & Ounces & Value & Ounces & Value \\
\hline 1880-1918. & $8,389,398$ & $\$ 5,598,314$ & $5,327,852$ & $\$ 3,666,820$ & 1, 319,889 & $\$ 931,396$ & $1,741,657$ & $\$ 1,000,098$ \\
\hline $1919 \ldots \ldots$ & 629,708 & 705,273 & 488,034 & 546,598 & 108,691 & 121,734 & 32,983 & 36,941 \\
\hline $1920 \ldots \ldots$ & 953,546 & $1,039,364$ & 682,033 & 743,416 & 246,292 & 268,458 & 25,221 & 27,490 \\
\hline 1921 & 761,075 & 761,075 & 545.229 & 545,229 & 193,281 & 193,281 & 22,565 & 22,565 \\
\hline 1022 & 729,945 & 729,945 & 622,978 & 622,978 & 80,598 & 80,598 & 26,369 & 26,369 \\
\hline 1923 & 814,649 & 668,012 & $7] 5,040$ & 586,333 & 77,237 & 63,334 & 22,372 & 18,345 \\
\hline 1924. & 669,641 & 448,659 & 572,078 & 383,292 & 75,284 & 50,440 & 22,279 & 14,927 \\
\hline 1925 & 698, 259 & 482,495 & 606,929 & 419,294 & 67,186 & 46,445 & 24,144 & 16,756 \\
\hline $1926 \ldots$ & 690,000 & 430,500 & 605,190 & 377,600 & 59,940 & 37,400 & 24,870 & 15,500 \\
\hline $1927 \ldots$ & 627,800 & 356,000 & 525,100 & 297,800 & 79,400 & 45,000 & 23,300 & 13,200 \\
\hline $1923 \ldots \ldots \ldots$ & 454,700 & $26 f i, 000$ & 350.430 & 205,000 & 80,340 & 47,000 & 23,930 & 14,000 \\
\hline $1929 \ldots \ldots \ldots$ & 472,300 & 252,000 & 351,730 & 187,400 & 94,370 & 50,300 & 26.800 & 14,300 \\
\hline $1930 \ldots \ldots$ & 408,570 & 157,300 & 279,990 & 107,800 & 102,080 & 39,300 & 26.500 & 10,200 \\
\hline $1931 \ldots \ldots$ & 352,000 & 102,000 & 193.850 & 56,200 & 129,800 & 37,600 & 28,350 & 8,200 \\
\hline $1932 \ldots \ldots \ldots$ & 234,050 & $6 ! \mathrm{i}, 000$ & 81,150 & 22,900 & 115.300 & 32,500 & 37,600 & 10,600 \\
\hline $\begin{array}{l}1933 \\
1934\end{array}$ & 157,150 & $\begin{array}{r}55,000 \\
100000\end{array}$ & $\cdots$ & $\ldots \ldots$ & 128,150 & 44,850 & 29,000 & 10,150 \\
\hline 1934 & 154,700 & 100,000 & i34 $400^{-}$ & 96,000 & 118,250 & 76,440 & 36,450 & 23,500 \\
\hline $1935=-$ & 2816,6080 & 206,000 & 134.400 & $\begin{array}{r}96,600 \\
236,000\end{array}$ & 106,600 & 76,600 & 45,600 & 32,800 \\
\hline $\begin{array}{l}1936- \\
1937\end{array}$ & $\begin{array}{l}475,600 \\
495,000\end{array}$ & 369,000 & $\begin{array}{l}31)+1,000 \\
285,000\end{array}$ & $\begin{array}{l}23 f, 000 \\
221,000\end{array}$ & $1] 9,800$ & $\begin{array}{r}93,000 \\
12000\end{array}$ & 51,500 & 40,0011 \\
\hline $\begin{array}{l}1937-- \\
1938\end{array}$ & $\begin{array}{l}495,000 \\
.74,940\end{array}$ & $\begin{array}{l}384,000 \\
307000\end{array}$ & 245,000 & $\begin{array}{l}221.000 \\
158,400\end{array}$ & 156,000 & 121,000 & 73,640 & 47600 \\
\hline $1939 \ldots$ & 203,500 & 138.000 & - & 100,400 & 128,500 & 87,000 & 75,000 & 51,000 \\
\hline Total ... & $19,133,831$ & $16,621,937$ & $12,916,613$ & $9,480,660$ & $3,743,285$ & $2,644,676$ & $2,473,930$ & $1,496,600$ \\
\hline
\end{tabular}

From the foregoing table it is readily apparent that there had been a steadily waning production of silver from 1920 to 1934, when the low point of 154,700 ounces was reached. There was a brief upward spurt, and for 3 years, 1936-38, the production of silver was about 475,000 ounces or more a year, but this was followed by the slump in 1939 to 203,500 ounces. It is probable that for several years this will continue to be about the average anmual output. The cause for these fluctuations is not hard to discover when one remembers the close interrelation that has existed between the content of: silver in the copper ores and the production of those ores. Thus the low points in silver production in 1933 and 1934 coincide with the cessation of copper production in those years. So, too, the lack of production of copper ores in 1939 resulted in the great decrease in the output of silver in that year. As is stated more fully on p. 78, all the large copper mines have definitely announced that their ore bodies have been worked out and that they have therefore discontinued operations. There is, therefore, no reason to expect that in 
the near future there will be any considerable amount of silver produced from this type of ore.

In thus attributing much of the variation in the quantity of silver produced to the rise and decline of copper mining it must not be overlooked that the fluctuations in the price for which silver sold have played a large part in determining the value of the Alaska silver output. Thus in the period 1919-22 the average selling price of silver was $\$ 1$ or more an ounce, whereas in 1931-32 it was less than 30 cents. Since 1933 the selling price has advanced considerably, partly through natural causes and partly through the action of the Government in setting the price it would pay for newly-mined silver from American sources. Throughout 1938 and up to July 1, 1939, the price, set by the President by Executive order on December 30, 1937, was $\$ 1.2929$ a fine ounce subject to a deduction of 50 percent for seigniorage and services by the Government. On July 6, 1939, these orders were modified, so that the seigniorage and charges became only 45 percent of the set price and the producer received 71.11 cents a fine ounce. The mean of these two rates, or approximately 67.88 cents a fine ounce, has therefore been taken as the average price paid throughout the year for silver that qualified under the law. According to the Engineering and Mining Journal, the average price during this period for silver that did not so qualify was approximately 39.08 cents an ounce. On the assumption that all the silver produced from, Alaska mines in 1939 qualified as eligible for purchase at the Govemnent price, its value; as stated in this report, has been calculated at that price.

The striking fluctuation in the average selling price of silver is clearly shown by the following table:

Average selling price of silver, 1880-1939

\begin{tabular}{|c|c|c|c|c|c|}
\hline Year & $\begin{array}{l}\text { Cents an } \\
\text { ounce }\end{array}$ & Year & $\begin{array}{c}\text { Cents an } \\
\text { ounco }\end{array}$ & Year & $\begin{array}{l}\text { Cents an } \\
\text { ounce }\end{array}$ \\
\hline $\begin{array}{l}1880-1918 \ldots \ldots \\
1919 \\
1920 \\
1921 \\
1922 \\
1923 \\
1924 \\
1925 \\
1926\end{array}$ & $\begin{array}{r}66.7 \\
112.0 \\
108.0 \\
100.0 \\
100.0 \\
82.0 \\
67.0 \\
69.1 \\
62.4\end{array}$ & $\begin{array}{l}1927 \ldots \ldots \\
1928 \\
1929 \\
1930 \\
1931{ }_{1} \\
1932 \\
1933 \\
1934 \\
1935\end{array}$ & $\begin{array}{l}56.7 \\
58.5 \\
53.2 \\
38.5 \\
29.0 \\
2.9 .2 \\
35.0 \\
64.6 \\
71.9\end{array}$ & $\begin{array}{r}1936 \\
\quad \text { a verage for period } \\
\quad \text { since } 1918\end{array}$ & $\begin{array}{l}77.57 \\
77.57 \\
64.64 \\
67.88 \\
\end{array}$ \\
\hline
\end{tabular}

In Alaska the development of ores that are valuable principally for their silver content is necessarily attended by many more difficulties and expenses than are likely to be met in developing gold mines. Among the most obvious reasons for this difference are the much lower value per unit of weight of the silver and the fact that more elaborate and expensive processes are usually required to re- 
cover silver in a readily salable metallic state than to recover gold. As a result, it is more or less unwarranted at this time to attempt to develop or even to search for silver lodes in remote parts of Alaska unless the ore has an especially high tenor. Therefore, although silver-lead lodes have been reported at many places in Alaska, few of them have appeared sufficiently attractive to induce persons with money to have the necessary examinations made and to undertake exploitation.

The Alaska districts that in the past have received most attention as possible sources of commercial silver mineralization were the Kantishna district, north of the Alaska Range in central Alaska, and the Hyder district, at the head of Portland Canal, in southeastern Alaska, and shipments of ore from both these places have been made to smelters in the States. It is believed that both of these districts would repay further exploration for workable silver ores, but although that search might be rewarded by success it is believed that any notable increase in production of silver in the near future is most likely to come from stimulation of mining of some of the lodes carrying silver mixed with other metals, such as gold, copper, and lead. This belief arises not through any skepticism that deposits of silver minerals occur in the Territory but rather through the knowledge that the mining of lodes of mixed sulphides is already making handsome returns in many places and the confidence that some of the deposits of this kind that are not now being mined might also, under capable handling, be brought into profitable condition.

\section{PLATINUM METALS}

Platinum is one of a group of several metals, which, because they are closely related in physical and chemical character, are often not differentiated by name or are not even identified specifically in the usual forms of assay or analysis but are spoken of as the "platinum metals," or, even more loosely, as "platinum." Platinum, palladium, iridium, osmium, ruthenium, and rhodium-all members of this group-have been recognized in the product from some of the lodes and placers in Alaska.

The spectacular increase in production of platinum metals from Alaska mines in 1938 marked one of the outstanding features of the mineral industry of that year, and the continuance of production in 1939 at a very high rate is of significance in the economics of the whole Nation. According to records of the Geological Survey, the production of platinum metals in Alaska in 1939 was equivalent to 27,230 fine ounces valued at $\$ 997,000$. It is true that this indicates a decrease in quantity of nearly 7,200 ounces and in value of about $\$ 230,000$ from the high record in 1938. A considerable decrease was 
to be expected because of the exceedingly late date at which the season opened in 1939 in the western placer platinum camps, and also because the site mined by the largest placer operator in 1938 was known to have an especially high tenor. The foregoing statistics, as far as they relate to quantity, are believed to have a high degree of accuracy, but the values stated are to be given much less dependence. The lesser claims for accuracy of the value of the product are due to several causes mainly arising through a rather unstable market for platinum metals and the wide fluctuations that are shown in the sales of each individual shipment. The shipments of placer platinum metals from Alaska show a constantly varying relation among the half dozen specific platinum metals they contain and in the inpurities and dross associated with them. The records collected by the Survey are not sufficienty detailed to show the exact composition of each lot of metal produced. This being the case, it is evident that to try to arrive at an average price per ounce for material composed of widely variable elements that range as greatly in selling price as do the several members of the platinum group leads to confusion that obscures rather than clarifies the main objective. The main part of the platinum metals derived from Alaska lodes is palladium, and a fairly well-established record of the price of that metal is quoted at frequent intervals by the Engineering and Mining Journal; Utilizing this record of the price of palladium and the average price of the group of platinum metals, as derived from that same source, a composite figure, $\$ 36.61$ a fine ounce; has been arrived at for the a verage value of the Alaska production of composite platinum metals in 1939. This compares with the average price of platinum metals: for the year as given by the Engineering and Mining Journal, which was approximately $\$ 36.75$ a fine ounce. As an indication of the approximate reliability of the figure used for the unit price in 1939, it may be noted that the comparable figure used in 1938 was $\$ 35.71$, when the average price of platinum metals as stated by the Engineering and Mining Journal was $\$ 35.90$ a fine ounce. In 1938 the amount. of the high-priced platinum metals in relation to the low-priced one, palladium, was practically the same. Even if the unit price that has been adopted should not prove to be strictly correct, it is probably sufficiently close to the fact to serve the useful purpose of correctly reflecting the magnitude of the industry in the Territory.

The outstanding development in the platinum-mining industry in Alaska, as well as in the United States proper, continued to be the placer-mining operations in the vicinity of Goodnews Bay, in the extreme western part of the Kuskokwim region, in southwestern Alaska. In this field the two principal mines are those of the Goodnews Bay Mining Co. and the Clara Creek Mining Co. These prop- 
erties, as well as the adjoining country, were examined in considerable detail in 1937 by a Geological Survey party in charge of J. B. Mertie, Jr. A summary report by him has recently been published and a more complete and comprehensive report by him on the district is now in course of publication. ${ }^{8}$ At the property of the Goodnews Bay Mining Co. mining is done with both a dredge and a dragline. At the property of the Clara Creek Mining Co. a dragline is used. Unlike most of the Alaska placer deposits that are mined by dredging, those in the Goodnews district are not permanently frozen and therefore can be excavated without long and expensive thawing operations, such as are required in the Nome and Fairbanks districts. The distribution of the platinum-bearing placer deposits appears to be quite strictly localized to the streams deriving their detritus from and around the flanks of Red Mountain, an intrusive mass of basic composition. As most of that area has now been covered by claims of the two larger companies, there are very few small camps or individual prospectors mining or seeking this type of deposit in the area, though before these consolidations took place there were a great number of such small outfits. During the season of 1939 there were between 65 and 70 men engaged in platinum mining in the Goodnews area.

Another significant contributor to the output of platinum metals from Alaska in 1939 was one of the lode mines on Kasaan Peninsula, in the Ketchikan district of southeastern Alaska. The principal platinum metal recovered at this mine is palladium, which, as already noted, sells for a much lower price than most of the other platinum metals, and which in 1939 rarely sold for more than $\$ 24$ an ounce. The development at this mine was being carried on by the Alaska Gold \& Metals Co., which has successfully operated the property since 1935. The ore is a basic sulphide, carrying in addition to the palladium considerable amounts of gold, copper, and silver, all of which are recovered from the concentrates shipped to the Tacoma Smelter for treatment. From the mine the crude ore is delivered to the mill, where it is passed through various crushers and subjected to concentration processes, including flotation. The property is in operation continuously during the year, though during the winter it is run on a reduced schedule.

The only other region in Alaska where some platinum metals are reported to have been recovered in 1939 is Seward Peninsula. In that region small amounts of platinum metals were recovered from

\footnotetext{
${ }^{8}$ Mertie, J. B., Jr., Platinum deposits of the Goodnews Bay district, Alaska: U. S. Geol. Survey Bull. 910-B, pp. 115-145, 1939; The Goodnews platinum deposits: U. S. Geol. Survey Bull. 918 (in press).
} 
gold placers on Dime Creek, a tributary of the Koyuk River, Quartz Creek, a tributary of the Kiwalik River, in the Fairhaven district, and in nearby areas in the extreme eastern part of the peninsula. The Koyuk district has long been a small though consistent producer of platinum as a byproduct. The streams derive their gravel in large part from the hills formed of Mesozoic basic effusive rocks which have been cut by granite intrusives, and in part from lower country, in which Paleozoic schists and limestones predominate. The bedrock source of the platinum metals has not yet been determined, though some ultrabasic igneous rocks have been recognized in proximity to the placers.

Although no other operators in Alaska are known to have produced and sold platinum metals in 1939, it is not at all unlikely that small amounts may have been produced elsewhere and held by their producers. Places where platinum has been recognized are widespread through other parts of Alaska, and some of them in other years have produced platinum that has been sold. Among these places may be mentioned the Chistochina district of the Copper River region; Metal Creek, in the Kenai district; some of the beach placers of Kodiak Island, in southwestern Alaska; the Kahiltna River and nearby streams, in the Yentna district of the Susitna region; Boob Creek, in the Tolstoi area of the Innoko district; Granite Creek, in the Ruby district of the Yukon region; and some streams in the Marshall district, in the western part of the Yukon region.

\section{COPPER}

For many years the copper production of Alaska miners has been second in value only to the gold production of the Territory and during the past span of years has accounted for more than $\$ 227,000$,000 of the mineral wealth that has come from Alaska. Obviously all mineral deposits have a limited extent, and as their mining is continued there necessarily comes a time when they become depleted and finally exhausted. The great copper mines of the Territory reached that state in 1938 and late in that year were definitely closed down by their managements. This of course does not mean that no other copper ores are known to occur in Alaska or that subsequently new deposits may not be discovered and developed. It simply means the closing of the great epoch of copper mining that began with the opening of the unique and phenomenally rich deposits near Kennicott in 1911 and ended with their final cessation in 1938. Henceforth, for at least some years, the only copper that is likely to come from the mines of the Territory is that recovered as an accessory or byproduct from ores that are valuable mainly 
for their content of some other metal. This was the source of the small amount of copper credited to 1939.

The following table shows the amount and value of the copper produced in Alaska since the earliest recorded mining of copper:

Copper produced by Alaska mines, 1880, 1900-1989

\begin{tabular}{|c|c|c|c|c|c|c|c|}
\hline \multirow{2}{*}{ Year } & \multirow{2}{*}{$\begin{array}{c}\text { Ore } \\
\text { mined } \\
\text { (tons) }\end{array}$} & \multicolumn{2}{|c|}{ Copper } & \multirow{2}{*}{ Year } & \multirow{2}{*}{$\begin{array}{c}\text { Ore } \\
\text { mined } \\
\text { (tons) }\end{array}$} & \multicolumn{2}{|c|}{ Copper } \\
\hline & & Pounds & Value & & & Pounds & Value \\
\hline $\begin{array}{l}1880 \\
19001915 \\
1916 \\
1917 \\
1918 \\
1919 \\
1920 \\
1921 \\
1922 \\
1923 \\
1924 \\
1925 \\
1926 \\
1927\end{array}$ & $\begin{array}{r}1,232,396 \\
617,264 \\
659,957 \\
722,047 \\
492,644 \\
766,095 \\
477,121 \\
581,384 \\
731,168 \\
761,779 \\
860,023 \\
670,000 \\
645,000\end{array}$ & $\begin{array}{r}3,933 \\
220,773,969 \\
119,654,839 \\
88,793,400 \\
69,224,951 \\
47,220,771 \\
70,435,363 \\
57,011,597 \\
77,967,819 \\
85,920,645 \\
74,074,207 \\
73,855,298 \\
67,778,000 \\
55,343,000\end{array}$ & $\begin{array}{r}\$ 826 \\
35,031,225 \\
29,484,291 \\
24,240,598 \\
17,098,563 \\
8,783,063 \\
12,960,106 \\
7,354,496 \\
10,525,655 \\
12,630,335 \\
9,703,721 \\
10,361,336 \\
9,489,000 \\
7,250,000\end{array}$ & 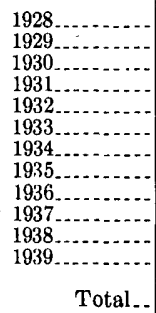 & $\begin{array}{r}579,500 \\
590,400 \\
531,000 \\
88,000 \\
56,900\end{array}$ & $\begin{array}{r}41,421,000 \\
40,510,000^{\circ} \\
32,651,000 \\
22,614,000 \\
8,738,500 \\
29,000 \\
121,000 \\
15,056,000 \\
39,267,000 \\
36,007,000 \\
29,760,000 \\
278,500 \\
1,374,511,000\end{array}$ & $\begin{array}{r}\$ 5,965,000 \\
7,130,000 \\
4,244,600 \\
1,877,000 \\
550,500 \\
1,900 \\
9,700 \\
1,249,700 \\
3,720,000 \\
4,741,000 \\
2,976,000 \\
30,000 \\
227,408,400\end{array}$ \\
\hline
\end{tabular}

In the foregoing table no quantity of ore mined is shown for the years subsequent to 1932 . This has been omitted partly because the large copper producers no longer made that information available but largely because much of the copper was derived as a minor byproduct of gold ores, so that the quantity of ore ceased to give a proper basis of comparison with the production of earlier years. Thus, in :1939, as stated, 'no ores were mined primarily for their copper content, and it would be manifestly misleading to tabulate the gold ores from which only small amounts of copper were obtained as though they really were copper ores.

The general trend of the copper-mining industry in Alaska is graphically indicated by one of the curves in figure 3, which shows the output of copper for each year from 1900 to 1939 . On the same diagram has been plotted the average price of copper for each year. The diagram tells its own story of the growth of the copper industry-from a meager start in the early boom days of the Territory, through fabulous strides in the days of the World War, when all nations were clamoring for copper and paying almost any price to get it and Alaska copper production rose to nearly $120,000,000$ pounds a year, then fluctuating up and down until 1923, when the trend became definitely downward and at an accelerating rate, until production practically ceased in 1933 and remained at an extremely low point in 1934 and then turned sharply upward as the operators attempted to salvage the remnants of such ore as could be cleaned out before finally closing the mines down in 1938 .

Among the mines whose principal mineral content of value was some metal other than copper, but which furnished concentrates 
from which copper was obtained, were those of the Nabesna Mining Corporation in the Alaska Range region, at the head of the Copper River region, in the valley of the Nabesna River, which is a tributary of the Tanana, and the Alaska Gold \& Metals Co., on Prince of Wales Island, in the Ketchikan district of southeastern Alaska. No considerable change in the amount of copper derived from these mines is to be expected in the future unless they greatly alter the size of their general mining operations.

That there are other places in Alaska where copper minerals occur is well known. That some of these deposits contained enough copper to enable them to be worked at a profit under past conditions is a

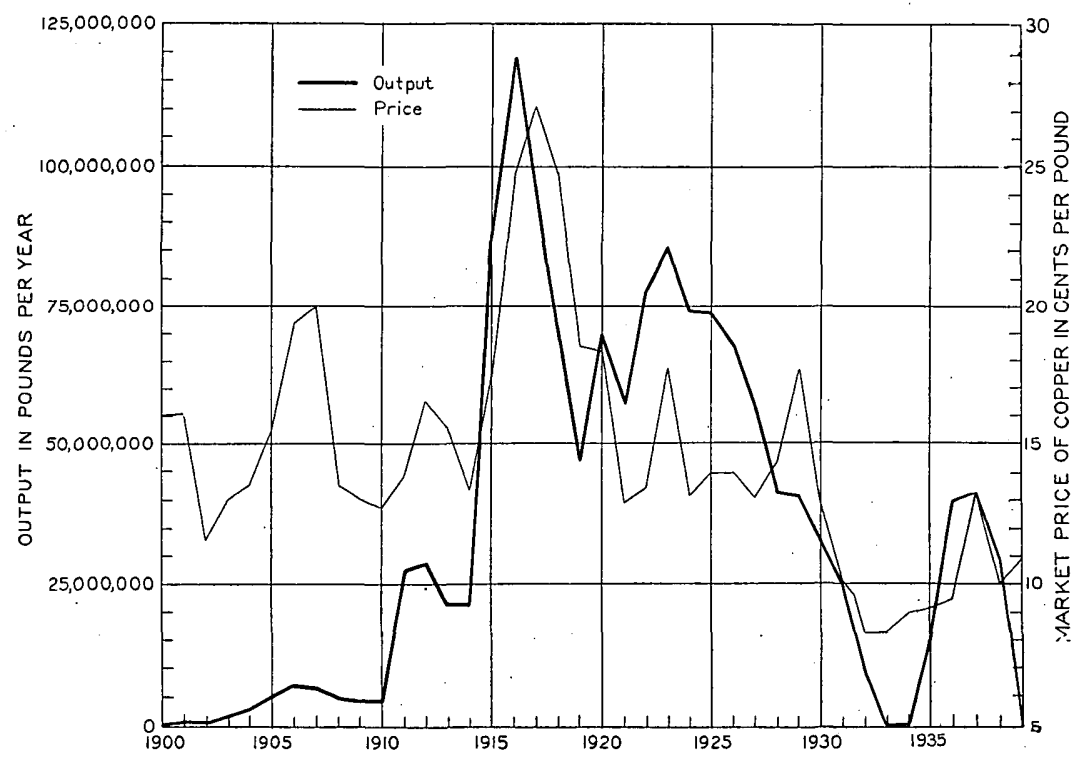

Figure 3.-Copper produced from Alaska mines, 1900-1939, and fluctuations in the price of copper during that period.

matter of history. It is extremely doubtful, however, whether any of the known copper deposits that are not now being mined can be worked at a profit under present conditions. As a consequence, practically all activity at properties of this kind has been discontinued and doubtless will not be resumed until the price of copper has materially advanced. That there may be deposits, as yet unknown, which might repay development is possible, but the incentive to search for them is so small and the probability of failure so great that prospectors are not willing to take the gamble. At present, therefore, search for new copper deposits or development of those already known has practically ceased. Obviously, no forecast can be made as to when these conditions are likely to change. Various remedial or palliative measures have been proposed, which might encourage 
the copper-mining industry, but it seems doubtful whether much improvement through such measures can be looked for in the near future. Indeed, the cessation of copper mining at the large mines points inexorably to the conclusion that hereafter the output of copper from Alaska mines will come only from the mines in which it is recovered as a byproduct of ores of gold or some other metal more sought as the principal object of mining. Some increase from this source is expected with considerable confidence.

\section{LEAD}

The lead produced from Alaska ores in 1939 is estimated to have been 2,120,000 pounds, or about 104,000 pounds less than in 1938 . This decrease is attributable to less production of ore from certain of the lode mines that are principally valuable for their gold, because all the lead is recovered as a byproduct from the concentrates of the gold ores. These concentrates are shipped to smelters in the States for treatment to recover all the valuable metals they contain. The average market price of lead in 1939, according to the Engineering and Mining Journal, was 5 cents a pound, which was about onefourth cent higher than the price that prevailed in 1938. At this price, the value of the Alaska lead production was $\$ 106,000$, which, although greater than for any other year since 1931 with the single exception of 1937, was much less than for some of the preceding years when the quantity produced was very much less.

Lead produced in Alaska, 1892-1939

\begin{tabular}{|c|c|c|c|c|c|c|c|c|}
\hline Year & Pounds & Value & Year & Pounds & Value & Year & Pounds & Value \\
\hline 1892. & 60,000 & $\$ 2,400$ & 1909. & 138,000 & $\$ 5,934$ & 1926. & $1,556,000$ & $\$ 124,400$ \\
\hline 1893 & 80,000 & 3,040 & $1910^{-}$ & 150,000 & 6,600 & 1927. & $2,016,000$ & 127,000 \\
\hline 1894 & 70,000 & 2,310 & 1911. & 102,000 & 4,590 & 1928 & $2,038,000$ & 118,000 \\
\hline 1895. & 40,000 & 1,320 & 1912 & 90,000 & 4,050 & 1929 & $2,630,100$ & 166,000 \\
\hline 1896 & 60,000 & 1,800 & 1913 & 12.000 & 528 & 1930. & $2,730,000$ & 136,500 \\
\hline 1897 & 60,000 & 2,160 & 1914 & 56,000 & 1,344 & 1931 . & $3,320,000$ & 126,000 \\
\hline 189 & 60,000 & 2,240 & 1915 & 874,000 & 41,118 & 1932 & $2,522,000$ & 75,600 \\
\hline 189 & 70,000 & 3,150 & 1916 & $1,640,000$ & 113,160 & 1933 & $2,314,000$ & 85,600 \\
\hline 190 & 80,000 & 3,440 & 1917. & $1,704,000$ & 146,584 & 1934. & $1,680,000$ & 62,100 \\
\hline 190 & 80,000 & 3,440 & 1918. & $1,128,000$ & 80,088 & 1935. & $1,630,000$ & 65,200 \\
\hline 1902 . & 60,000 & 2,460 & 1919 & $1,374,000$ & 72,822 & 1936 & $2,116,000$ & 99,500 \\
\hline 1903 & 60,000 & 2,520 & 1920. & $1,750,000$ & 140,000 & 1937. & $2,004,000$ & 120,400 \\
\hline $1904 \ldots$ & 60,000 & 2,580 & 1921 & $1,518,000$ & 68,279 & 1938 & $2,224,000$ & $\mathrm{j} 05,400$ \\
\hline 1905 & 60,000 & 2,620 & 1922 & 754,000 & 41,477 & 1939. & $2,120,000$ & 106,000 \\
\hline 190 & 60,000 & 3,420 & 1923 & 820,000 & 57,400 & \multirow{3}{*}{ Total } & & \\
\hline 190 & 60,000 & 3,180 & 1924 & $1,262,000$ & 100,899 & & $46,950,000$ & $2,588,600$ \\
\hline & 80,000 & 3,360 & 1925 & $1,578,000$ & 140,571 & & & \\
\hline
\end{tabular}

Practically all of the lead that is reported in the foregoing table as produced in 1939 was recovered in the course of treatment of the gold ores of the Alaska Juneau Gold Mining Co.'s mines, in southeastern Alaska. According to the published reports of this company, it recovered less than half a pound of lead from each ton of ore that was mined and trammed to the mill, or less than $0.86^{\circ}$ pound 
of lead from each ton of ore that was fine-milled. From the table on page 17, showing the recovery of metals at the Alaska Juneau mine, it is evident that the total quantity of lead recovered from the total quantity of ore that was fine-milled has remained prạctically constant, as the average for the entire period of the mine's operation since 1914 is 0.90 pound of lead to the ton of ore that is fine-milled.

Ores containing greater or lesser quantities of lead minerals are widely known throughout the Territory, and in the past shipments valuable at least in part for their lead content have been made from many areas in southeastern Alaska, especially the Hyder district; from the Yukon-Tanana region, especially the Kantishna district; and even from far-away Seward Peninsula, at the Omilak mine, and from the Kobuk district in the vicinity of Shungnak. Lead is, however, a heavy, low-priced commodity that requires rather elaborate treatment to produce in readily salable metallic form, and these draw-backs, coupled with the low current price for the metal, act as deterrents to the development of lead deposits in remote regions. The outlook for any notable increase in the production of this metal, therefore, seems to depend on the stimulation of the mining of other metals and the consequent increase in the production of lead as a byproduct. That this increase in mining of lodes of mixed metallic content is likely to take place is regarded as a certainty, and that some of the silver-lead deposits now lying idle will be opened up again seems almost equally certain. As general business conditions throughout the world improve and as development and transportation facilities in Alaska improve, an increase in the output of lead from Alaska ores is looked for with considerable assurance.

TIN

For many years Alaska has been a small but regular producer of tin, and in the course of the more than a third of a century since tin minerals were discovered in Seward Peninsula and later elsewhere in the Territory it has shipped tin worth nearly $\$ 1,600,000$. During 1939 the production of tin from Alaska mines is estimated to have been 74,080 pounds of metallic tin valued at $\$ 37,300$. This marks a considerable decrease in both quantity and value as compared with the preceding year, but it is still by far the largest amount of tin that is produced anywhere within the limits of the United States or its possessions. All the Alaska tin was derived from the mineral cassiterite $\left(\mathrm{SnO}_{2}\right.$; tin 78.6 percent, oxygen 21.4 percent), which occurs in placers mixed with gravel and rock detritus and is recovered by processes that are essentially the same as those used in placer-gold mining. The tin is then obtained in metallic form from the cassiterite by smêlting, which is done outside Alaska. 
The principal producing tin properties in Alaska lie in the extreme western part of Alaska, near the western tip of Seward Peninsula. In addition to a few small one- and two-man camps that are fairly widely distributed in this general region, the main tin-mining activity is on the property of the American Tinfields, Inc., near Tin City. The tin-bearing placers that are now being mined occur around the eastern border of Cape Mountain, a granite mass that forms the westernmost limit of the North American continent and has been intruded into a country rock consisting of limestones and slates that had been much metamorphosed even before the intrusion of the granite. The tin minerals have been found in place in the contact zone of the granite, and attempts have been made in the past to develop some of the richer areas as lode mines. Somewhat similar conditions, prevail at other points in western Seward Peninsula, where in the past both tin lodes and placers have been found and a number of the placers mined extensively.

Although they contributed only a small amount of tin to the total output from Alaska mines in 1939, mention should be made of the placer deposits in the Hot Springs and Ruby districts of the YukonTanana region, which, though mined mainly for their gold content, afford a small but rather constant amount of tin minerals each year. None of the tin minerals now mined from either of these smaller deposits or from those of Seward Peninsula are at the present time reduced in smelters in the United States. The metallurgy of their reduction, however, involves no great difficulty, so that if a sufficient and constant supply were available it would be entirely practicable to smelt it in the States.

The complete record of tin production from Alaska is given in the accompanying table:

Tin produced in Alaska, 1902-1939

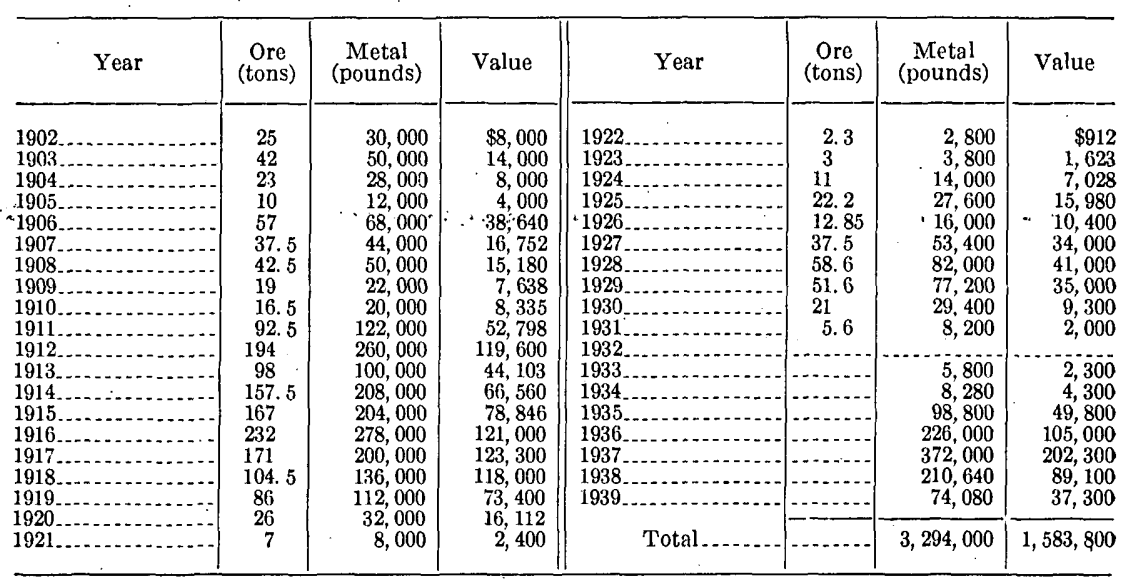


The importance of tin in our national economy and the dearth of workable tin deposits throughout most of the States make the future of the Alaska deposits a matter of special national significance. The facts are not yet in hand to warrant expressing any fixed conclusion as to the quantity of tin these deposits may supply under hypothetical conditions. The showings already made do, however, justify certain tentative opinions. Some of these facts may be summarized as follows: (1) Tin minerals in considerable quantities have already been recovered from certain areas in Seward Peninsula; (2) other nearby areas as yet not equally developed appear to have similar geologic setting and presumably may contain deposits of equal value; (3) certain areas adjacent to those containing workable placers or that are likely to contain such placers have been subjected to geologic processes that are capable of producing placers of other types than those now receiving attention, for instance, old beach concentrations; (4) the angularity of much of the tin ore in the placers and the size of many of the fragments, which show that the material has probably been transported a short distance, point to a rather local source for the mineralization and suggest the possibility of discovering lode deposits of commercial value. As yet none of the inferences that may be drawn from the foregoing facts have been tested critically by being confronted with the practical problem of furnishing quantitative information as to the amount of tin there is in various deposits. Obviously answers to these questions cannot readily be obtained without the outlay of considerable time and money under expert technical supervision. Complete answers to all the questions involved would go beyond what the Government could reasonably undertake. As a start and to show whether further work along those lines may not be justified, the Geological Survey had a party in charge of J. B. Mertie, Jr., commence intensive field investigation of the Seward Peninsula tin deposits in the season of 1939 . The work in that season was rather closely restricted to the area immediately adjacent to Cape and Potato Mountains, but it will be continued another season so as to cover all other prospective tin areas in the general district and will embrace quantitative determinations as to both the lodes and the placers so far as can be made with the available funds and personnel. Reports of the results of Mr. Mertie's findings will be issued as rapidly as the necessary laboratory and office studies can be carried through after the completion of the field work.

In focusing the activities of the Survey's search for tin in Alaska. on the possibilities of the development of tin on the area in western Seward Peninsula, it should not be forgotten that the occurrence of tin minerals in other parts of Alaska has been amply demonstrated. That further intensive examination of some of these other 
deposits is highly desirable is obvious, but their geologic settings are more obscure and their physical surroundings are such that determination of their real merits is likely to present difficulties that cannot easily be solved.

\section{COAL}

The coal produced from Alaska mines in 1939 is estimated to have been 146,250 tons, an amount that has been exceeded. only in one year since coal mining began in the Territory. In addition to the coal mined in Alaska, 26,347 tons was imported from fields outside Alaska, and no Alaska coal was exported. The consumption of coal in Alaska in 1939 was thus 172,597 tons, or about 21,731 tons less than in 1938. The local consumption of coal is being supplied more and more by increased output of the domestic mines. A comparison of coal production and consumption in Alaska for the entire period for which records are available is afforded by the following table:

Coal produced and consumed in Alaska, 1880-1999

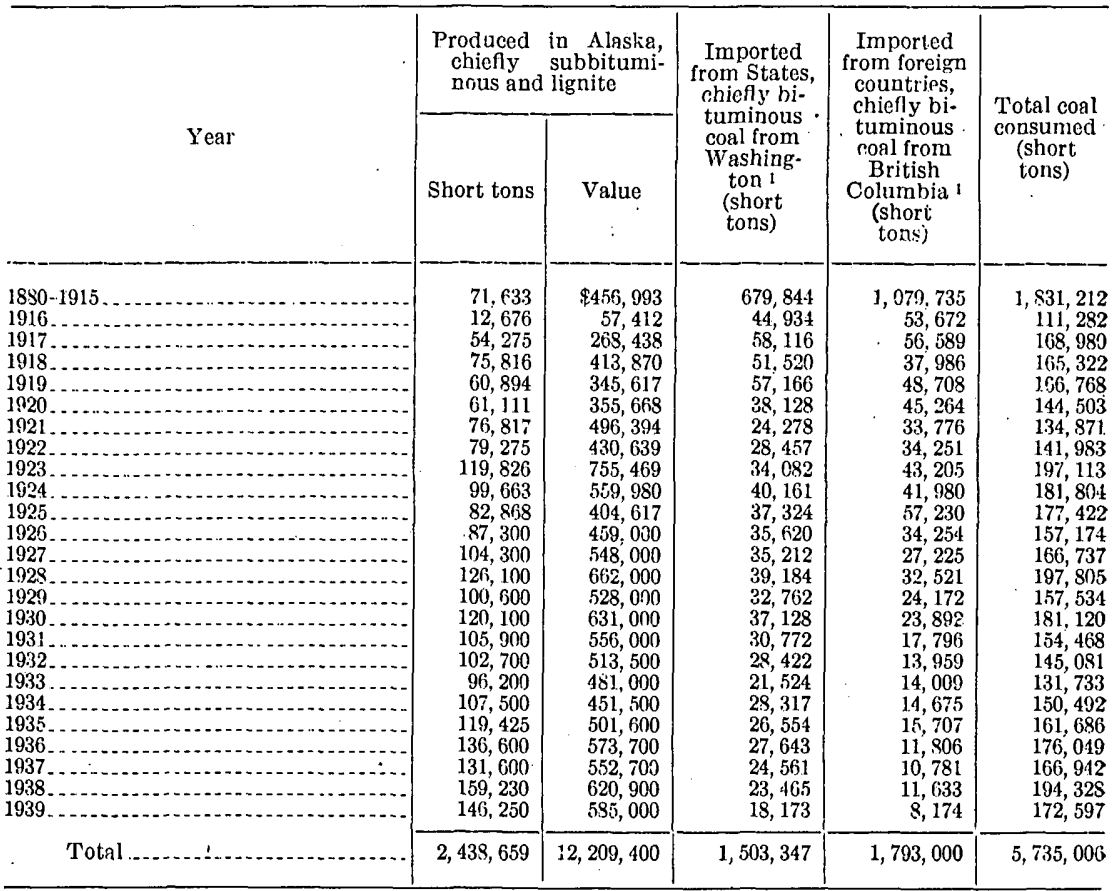

1 Compiled from reports from Bureau of Foreign and Domestic Commerce. No figures on imports before 1899 are available.

In this table the total value of the coal produced in Alaska in 1939 is stated to have been $\$ 585,000$. The value can be regarded only as a fair approximation, because records are not available for precise determination of the actual selling price of the coal. Much of the 
coal is purchased by The Alaska Railroad on contract for large quantities, or produced by that organization for its own use, so that the price paid by the railroad or charged on its books is not a suitable index of the price paid for the lots sold to the smaller consumers, who in the aggregate buy a rather large part of the output and pay much higher prices. From all the available information, and by weighting the resulting estimate as closely as practicable, it: appears that the average price of the coal mined in Alaska in 1939 may be taken as $\$ 4$ a ton. This is 10 cents a ton more than the estimated price in 1938 and is about $\$ 1.07$ a ton less than the average price that prevailed during the period 1880 to 1938 .

Practically all the Alaska coal mined in 1939 came from two mines-one in the Matanuska field and one in the Nenana, or Healy River field. The principal mine in the Healy River field was that of the Healy River Coal Corporation and in the Matanuska field that of the Evan Jones Coal Co., at Jonesville. Still smaller amounts of coal came from the mine of the Houston Fuel Co., near Houston, which is situated not far west of the developed portions of the Matanuska field; from a small deposit on Kugruk River in Seward Peninsula; and from beds exposed on Kuk River, south of Wainright, in northern Alaska.

The largest coal mine in the Territory is that of the Healy River Coal Corporation, in the Nenana field. The mine is situated in the valley of Healy River, about 4 miles east of the junction of that stream and the Nenana River. The plant of this mine has been well laid out and is now equipped with the necessary modern machinery to handle between 300 and 400 tons a day. The coal beds that are being mined are of Tertiary age, comparable with those in the Matanuska field, but the individual beds are much thicker and the measures have suffered much less deformation through mountain building than those in the southern area. Probably owing to the lesser amount of folding that the beds have undergone, the coal of the Nenana field is a highgrade lignite, which has a somewhat lower heating value than that from the Matanuska and nearby fields; as a consequence, it is not used in the railroad locomotives, but the shorter haul makes its use more economical in many parts of the interior. This mine was in continuous operation throughout 1939 and yielded considerably more than half the coal mined in Alaska during that year. The largest single user of coal from this property is the United States Smelting, Refining \& Mining Co., Fairbanks Exploration Department, which utilizes it for furnishing power to its dredges and in its large placer-mining cperations in the vicinity of Fairbanks. The constantly growing demands by that company for more power require an increasing quantity of coal. The Healy River coal is also extensively used for power 
and domestic fuel at other points in Alaska, even as far distant from the mine as Cordova. Some difficulty was experienced during the year owing to a fire that is believed to have originated spontaneously in the underground workings on bed No. 6, in the first crosscut above the gangway between rooms 107 and 108. The fire was discovered May 5, but it was well into August before it seems to have been gotten under control. During that time the fire had spread widely and had destroyed considerable coal but had not seriously interrupted the general operation of the mine.

The mine of the Evan Jones Coal Co., in the Matanuska field, is situated on a spur of the former Chickaloon Branch of The Alaska Railroad, about 16 miles in an air line northeast of the settlement of Matanuska. Its coal is of bituminous rank and in. steam sizes has been practically the only fuel used in locomotives or for power purposes by The Alaska Railroad. The larger sizes are extensively used for domestic purposes, and much of the product finds a ready market throughout western and central coastal portions of Alaska, especially in the schools under the direction of the Office of Indian Affairs and in some of the canneries. Operations at this mine are reported to have proceeded at about the normal rate throughout most of the year, though during all of July and a large part of August the production of coal was practically suspended while repairs and reconditioning of the plant were in progress.

For many years The Alaska Railroad has maintained in a standby condition its own mine at Eska, a mile or so east of Jonesville, which had been opened on the same general series of coal beds as those mined by the Evan Jones Coal Co. This policy was continued, and in 1939 a small amount of work was done at this mine to replace some of the old timbers, clear out small falls of rock that had slabbed off the walls, and do other minor jobs so that the property could quickly be put into production again should an emergency arise that might jeopardize the railroad's other sources of fuel.

As noted on p. 86, during 1939 small amounts of coal were reported to have been mined or prospecting for coal was in progress during the year near Houston, a station on the The Alaska Railroad some 20 miles west of Matanuska, and at one locality in Seward Peninsula and at two or three points along Kuk Lagoon, south of Wainwright, in northern Alaska. The coal from these different properties was used only locally and had no significant effect on the general Alaska coal situation, except to confirm the statement, often made before, that throughout the Territory there are many areas containing coal adequate for local use.

So far as the Geological Survey is informed, no production was made during the year from the known coal deposits on Admiralty 
Island, in the Juneau district, where some activity had lately been shown. In the Bering River field, where extensive deposits of coal ranging in composition from bituminous to anthracite have long been known to occur, prospecting or other development work relating to the coal resources apparently continued to remain at a standstill in 1939. Rumors of renewed activity in this field were heard from time to time, and extensions of some of the Government permits for coal prospecting there had been asked for, as the old permits were nearing expiration. It is evident that this field has much potential value, but it is also evident that the present coal consumption of Alaska is not such as to stimulate large companies to undertake extensive projects and that until there is a greater demand for their product or until they are prepared to invade a more distant market, where competition will be more severe, they will not enter this field. Furthermore, the development work already done in this field indicates that some complex geologic conditions will be encountered, so that desultory prospecting by small, poorly financed, or technically unskilled operators holds little promise of success, and full development must await a company that is able to go into the matter in a large way and to bear the necessarily uncertain expense of exploring a new field.

The whole problem of the development of Alaska's coal resources is exceedingly complex, for although there are in the Territory large areas occupied by coal-bearing rocks, the present local demands are fairly well supplied by existing mines, and to attempt to enter a larger field would require not only large outlays for developing mines but also perhaps even greater difficulties in establishing profitable markets. Obviously, many consumers are unwilling to commit themselves to any specific agreements to purchase until they are sure that the coal offered them is available at a satisfactory price, and the mining operator, of course, in the initial stages can offer little definite assurance as to costs and availability of his product until he has some certainty as to his market. Certainly many of the steps that must be taken, if any extensive use of Alaska coal is to be made, require that the enterprise be undertaken on such a scale as will justify the outlay for the essential facilities. This means that a considerable tonnage must be marketed, but the attempt to dispose of a large tonnage of Alaska coal will bring it into competition with coals from other areas and in places where the competitive conditions appear to be almost insuperable for the Alaska product. Many of the competitive conditions are changing, however, so that the situation must be subjected to constant review. Of course, as Alaska develops and becomes more settled, its people and industries will call for more 
and more coal, and in meeting this demand Alaska coals will have certain great competitive advantages over those from outside sources. That growth, however, probably will be relatively slow though none the less sure.

\section{PETROLEUIM}

No petroleum was produced from any Alaska deposits in 1939, although for a number of years prior to 1934 a small but significant production of petroleum had come from wells of the Chilkat Oil Co., in the Katalla district, east of the mouth of the Copper River. Even during the period that this company was active the supply of petroleum products from that source was by no means adequate to meet the constantly increasing demand for fuel and lubricants created by the increasing use of machinery. This lack of a local supply was met in 1939, as it had been in earlier years, by imports from the States. The accompanying table shows the amount of petroleum products that were imported into Alaska during 1939, as well as during the preceding years.

Petroleum products shipped to Alaska from other parts of the United States, 1905-99, in gallons ${ }^{\text {12 }}$

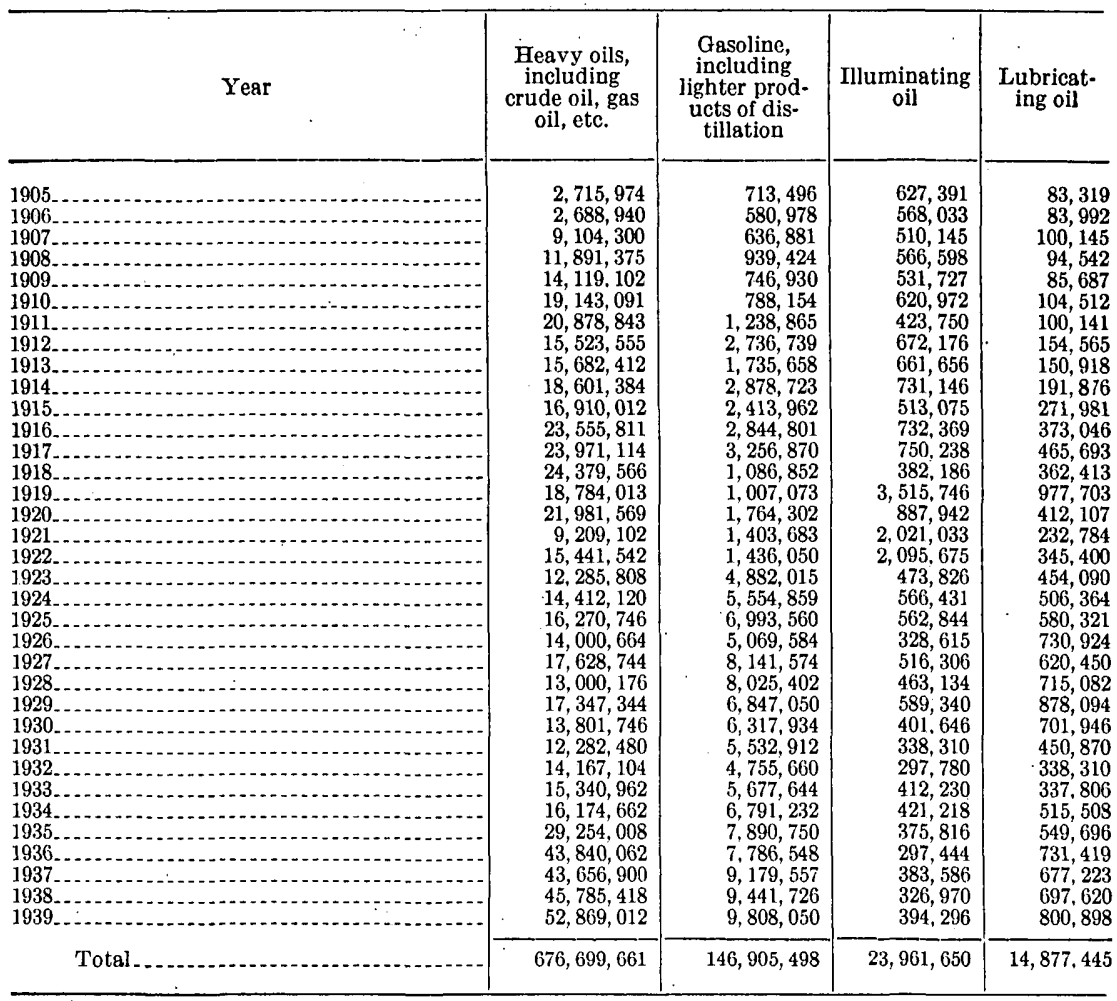

1 Compiled from reports of Bureau of Foreign and Domestic Commerce. 
From the foregoing table the great change in the types of different petroleum products imported and the amounts of each type during the period of record are readily apparent. Thus the illuminating oils, which in the period from 1919 to 1922 formed a considerable part of the imports, have dropped to less significant amounts since 1922 . Importations of heavy oils, which have always formed the bulk of the petroleum imports to Alaska, increased in the last few years, until in 1939 they amounted to more than three and a half times the average for the period from 1921 to 1932 . This great increase undoubtedly reflects the growing use of Diesel-equipped apparatus at many. of the mines, on tractors, and on vessels of the fishing fleet. It should also be noted that, whereas in 1920 the importation of gasoline was about 1,764,000 gallons, in 1939 it was practically 9,808,000 gallons, or about five and a half times that of the earlier year. This increase is, in considerable measure, in direct response to. the increasing mileage of available roads and the attendant increase in the number of motor vehicles that use them, as well as the increased mechaniza. tion of mining equipment in general.

Search for new oil fields in Alaska, which after numerous hectic booms in the past have practically ceased, began in 1936 to be revived and in 1939 was attracting considerable attention, even though at only two places had the new search reached the stage of drilling test wells. This drilling work was carried on by the Iniskin Drilling Co., which had extensive holdings in the Iniskin-Chinitna district on the west coast of Cook Inlet, in the Alaska Peninsula region, and by a combination of oil companies that had united in their efforts to test part of the known geologic structure in the vicinity of Jute Bay, northeast of the settlement of Kanatak on Cold Bay. Drilling in the Iniskin area was a continuation of the work started on a structure near Fitz Creek in 1936 and that had been carried to a depth of 7,156 feet when work was discontinued for the season in 1938. Work was resumed in 1939 at this depth, and before the work for that season was stopped drilling had been carried to a depth of approximately 8,775 feet. Unfortunately, salt water was encountered some distance above the bottom of the hole, and as they lacked suitable equipment for handling it or closing it off and as it was late in the season, the operators felt impelled to discontinue the work.

Although showings of oil and gas had been noted at several horizons in the lower 1,000 feet of the drill hole, no commercial pools were disclosed, and the incursion of the salt water prevented adequate testing of even those showings that were noted in the hole. That oil actually occurs in the area was demonstrated by the fact that some was collected from the drill holes and used in the operation of 
the trucks and in the heating apparatus at the camp. No announcement has been made concerning plans for work at this place another season. Some doubt has been expressed as to whether the new rules affecting prospecting permits on prospective oil areas may be such as to warrant going ahead with the project, even though the operators feel that there is a chance for finding oil in some of the deeper beds that lie below the present bottom of the drill hole. The work so far has been very expensive, costing perhaps four times as much as similar drilling would have cost in many of the oil fields in the States. Therefore, unless especially favorable terms can be arranged, it is likely that further drilling at this place will not be resumed in the near future.

The drilling in the vicinity of Kanatak was done by a joint organization representing the Standard Oil Co. of California, the Tide Water Associated Oil Co., and the Union Oil Co. of California. The site selected is in the Bear Creek Unit area, at the head of Salmon Creek, about 4 miles from Jute Bay, approximately in sec. 10, T. 30 S., R. 41 W., Seward meridian. The surface rocks at the drill site are correlated by the company's geologist with Middle Jurassic formations. Active work on this project was resumed on April 23, 1939 , at a depth of 2,430 feet-the point at which work for the season was discontinued in the fall of 1938. From that time to November 14 the drilling progressed with little interruption or unusual features to a depth of 6,295 feet. The exact date that drilling was suspended in the fall is not known, but apparently it was continued into early December. In that case it is evident that the bottom of the hole was somewhat deeper than that stated above. No changes were noted in the rock cores indicating that there was any stratigraphic break in the sections drilled which might mark rocks of a different geologic series. The whole section is therefore regarded as of Middle Jurassic age. No showings of commercial quantities of oil were reported. No public announcement as to the plans of the company for continuance of drilling in this area has been made.

In connection with the general development of oil claims in both Alaska and the States there is a widespread misunderstanding as to the real significance of Government permits for exploration for oil. Hundreds of such permits have been issued by the Government and cover tracts in all parts of Alaska and are outstanding in the hands of individuals or companies, but most of them were evidently taken up solely for speculative purposes and will lapse if no active work is done under them. As prospecting permits for oil are issued on application, without regard to the merits of the land involved as a favorable place in which to search for oil, the investing public 
should be warned that a permit from the Government is only what it purports to be-permission to search for oil-and in no way implies that the search has even a remote chance of being successful. Furthermore, the public should realize that prospective permits, if within the law, are readily granted by the Government at a nominal charge, and so should be warned against unscrupulous individuals who offer their services in obtaining permits for their clients at a charge far in excess of any reasonable fee for any service they render and of any payment required by the Government.

\section{MISCELLANEOUS MINERAL PRODUCTS}

The list of minerals of value that have been found in Alaska is long. In addition to those described in the preceding sections of this report, others which at one time or another have been produced in quantities large enough to have more than local significance and some of which have been the basis of profitable mining industries include, among metallic products, antimony, arsenic, bismuth, chromium, iron, mercury or quicksilver, molybdenum, nickel, tungsten, and zinc; and among nonmetallic products, asbestos, barite, building stone, clay, garnet, graphite, gypsum, jade, limestone, marble, and sulphur. Without doubt small quantities of practically all these materials were "produced" in 1939 in the broadest sense of that word, but none of them, with the exception of antimony, limestone, and quicksilver, are known to have been produced and sold in quantities valued at as much as a few hundred dollars. In the following table, as well as in some of the other tables in this report, all of these minerals that were produced by a single operator only or in quantities so small that to list them separately would disclose the production of individual operators have been grouped together under the collective term "miscellaneous mineral products." Included in this table among the miscellaneous mineral products are the platinum metals, although they have also been described elsewhere in this report. The inclusion of the value of the platinum metals is a relic of the period when practically the entire production of platinum metals in Alaska came from one mine and so could not be disclosed. Now that there are several producers of platinum metals, inclusion of that group among the miscellaneous mineral products is no longer necessary or desirable from certain points of view; but in order that there may be a fair comparison of the production of the minerals grouped together as miscellaneous products in earlier years with those same products in 1939, it has been considered desirable still to include the value of the platinum metals in this table. In other words, for 1939 the item shown in this table as $\$ 1,120,700$ may be broken down into miscel- 
laneous mineral products other than platinum, $\$ 123,700$, and platinum metals, $\$ 997,000$.

Value of output of miscellneous mineral products of Alaska, including platinum, petroleum, quicksilver; stone, antimony, 'gypsum, marble, and other products, 190.1-99 ${ }^{1}$

\begin{tabular}{|c|c|c|c|c|c|}
\hline Year & Value & Year & Value & Year & Value: \\
\hline 1901 & $\$ 500$ & $1915 \ldots$ & $\$ 205,061$ & 1929. & $\$ 194,000$ \\
\hline 2. & 255 & 1916 & 326,737 & 1930. & 157,300 \\
\hline 1903. & 389 & 1917 & 203,971 & 1931 & 108,000 \\
\hline$\ldots . .$. & 2,710 & 1918 & 171,452 & 1932. & 223,400 \\
\hline$\ldots \ldots+$ & 710 & ........... & $21.4,040$ & 1933 & 39,200 \\
\hline 1906 & 19,965 & $1920 \ldots \ldots$ & $99^{\prime}$ & $\ldots$ & 86,400 \\
\hline 1907 & 54,512 & $1921 \ldots \ldots$ & 235,438 & 1935 & 299,700 \\
\hline 1908 & 8 & $1922, \ldots \ldots$ & 266,296 & 1936 & 293,800 \\
\hline 1909 & 8 & 1923 & 229.486 & $1937--$ & 615,600 \\
\hline 1910 & 96 & $1924 \ldots \ldots$ & 348,728 & 1938 & $1,338,600$ \\
\hline $1911 \ldots \ldots \ldots$ & 141,739 & $3925 \ldots$ & $454 ; 207$ & $1939 \ldots$ & $1,120,7() 0$ \\
\hline 1912 & 165,342 & $1926 \ldots$ & 444,500 & & \\
\hline $\begin{array}{l}1913 \ldots \ldots \\
1914 \ldots \ldots\end{array}$ & 286,277 & $\begin{array}{l}1927 \ldots \\
1928\end{array}$ & 162,000 & & $9,765,800$ \\
\hline & & & & & \\
\hline
\end{tabular}

$1 \$ 117,000$ of placer platinum metals mined prior to 1926 and $\$ 238,000$ of antimony mined prior tó 1927 not distributed by years but carried in total.

The only significant production of antimony ore from Alaska mines in 1939 came from the property of Morris P. Kirk \& Sons, Inc.; on Stampede Creek in the Kantishna district, in the northern foothills of the Alaska Range. Antimony ore has long been known to occur at that locality, but prior to 1936 no systematic mining of the deposit had been attempted. Since 1936 the present company has been active in developing its property and has shipped out considerable ore. The mine is developed by a vertical shaft and adit from which open: ings have been made into the ore body. No first-hand information is available to the Geological Survey as to the recent operations at this property. It is currently reported that during 1939, in addition to the regular mining work, a long crosscut was driven to get under some of the rich ore bodies that had been encountered in the upper levels during the earlier development of the property. It is also currently reported that milling equipment was installed to concentrate some of the stibnite in the material that had been mined, which was not of sufficiently high grade to pay for shipping as crude ore. It would seem that such concentration was well worth while, not only in reducing shipping charges but also in increasing the amount of mineral that can be obtained from the deposit. As is well known, antimony is one of the metals that is much in demand for war purposes, and the United States does not have within its own borders a supply adequate for its national needs. The importance therefore of developing and utilizing to their full extent all deposits that can supply the national deficiency is especially pressing at this time. The average price of antimony, according to the quotations given $277199-41-7$ 
by the Engineering and Mining Journal, was 12.36 cents a pound in 1939 , which was essentially the same as the price of 12.35 cents a pound that prevailed in 1938, but during the last 3 months of 1939 the average monthly price was 14 cents a pound.

The quarrying of limestone as an ingredient of cement afforded a considerable part of the amount credited here to miscellaneous minerals in 1939. This enterprise is conducted by Superior Portland Cement, Inc., of Seattle, operating under lease from the Pacific Coast Cement Co. The quarries at which this high-grade limestone is mined are on Dall Island, in the Ketchikan district of southeastern Alaska. From the quarries at this locality the rough stone is shipped in barges to Seattle, where it is treated and mixed with the other constituents of the cement. This property has been productive for several years, but ordinarily it is possible to supply all the limerock needed by the company by keeping the quarries in operation only part of the year. In accordance with this practice, the quarries were in operation in 1939 only from March to October, inclusive. The records showed a somewhat smaller quantity of limestone shipped from the property than was quarried during the year. The quantity mined in 1939 was considerably more than in 1938.

Cinnabar, the principal ore of quicksilver or mercury, has been recognized in the concentrates from the placer deposits in many parts of the Territory, but in most of these places the lodes from which the cinnabar originally came were apparently small stringers that appear unlikely to afford ore that can be mined under present conditions. In the central and western parts of the Kuskokwim Valley, however, extensive areas of cinnabar in bedrock have long been known to occur which appear to hold promise of containing quicksilver deposits that may be profitably developed, though much further exploration will be required to determine their real value. One of the better known of these areas is in the vicinity of the settlement of Sleitmut, on the Kuskokwim, near the mouth of the Holitna River. Unconfirmed reports from this area indicated that during the year a few old-timers had gotten out a little ore, but that owing to the fact that no suitable furnaces were available for treating the ore, they had been unable to extract the mercury in a metallic state. The part of the Kuskokwim region where most of these showings of quicksilver ore occur is so remote that it is difficult and expensive to test out thoroughly the various places where mineralization has been recognized. The exceedingly rich specimens of mercury ore that have been found occasionally in the course of such prospecting as has been done encourages further search for deposits of commercial value, but it has not yet been demonstrated whether these pieces come from small rich stringers, possibly 
too narrow and too scarce to mine, or from offshoots from a workable body of ore.

Although the foregoing notes cover all the mineral products that contributed to swell the total output from Alaska during the year, they by no means have given account of all the significant prospecting that has been in progress or of the deposits that are temporarily lying dormant. As an example of the Jatter class may be mentioned the temporary cessation of production at the well-known quarries of the Vermont Marble Co., in southeastern Alaska. These quarries are on the west coast of Prince of Wales Island, not far from the small settlements of Tokeen and Calder. No productive mining was done there during 1939 , though the property was kept in condition so that work could be resumed promptly when required. The general practice of this company has been to operate these quarries actively at intervals and supply all the stone needed for the ensuing years, during which time the quarries are kept only in a stand-by condition. Thus these quarries have lain dormant since 1932. The stone is used in many of the larger and better buildings in the whole Pacific coast region, being especially in demand for interior trim and decoration. Ordinarily the company ships its rough stone from Alaska to finishing plants that it maintains in Tacoma, Wash., and San Francisco, Calif. There is, of course, no basis for believing that the cessation of quarrying during the year means the permanent closing of the property. It only marks a halt in production until sales of the product on hand deplete the stock so that replacements are needed, and there is every indication that this will occur shortly, so that the quarries will again be running. Limestone and marble are widely distributed throughout southeastern Alaska, and, according to Burchard, ${ }^{9}$ many different grades, some even approaching statuary quality, are found in the region. It therefore seems certain that some of these limestone and marble deposits, many of which are favorably situated with respect to deep-water transportation, will ultimately be profitably developed.

Revival of activity was reported at the gypsum deposits that have long been known to occur in the vicinity of Iyoukeen Cove, Chichagof Island. This was shown by the incorporation of the Camel Gypsum Co. to open up deposits some $1 \frac{1}{2}$ miles east of the former workings on this cove. For a while 18 men were employed, mostly on construction of structures and buildings for the surface plant and wharf. Some underground development of the deposit of gypsum was in progress by means of a short tunnel, from which it is proposed later to sink an inclined shaft on the ore body. So

\footnotetext{
9 Burchard, E. F., Marble resources of southeastern Alaska : U. S. Geol. Survey Bull. 682, pp. 29-39, 1920.
} 
far as could be learned there was no actual production of gypsum in 1939, except such as was taken out in the course of driving the underground openings. The property apparently consists of eight mining claims.

Chromium is another of the metals that occurs in Alaska deposits, and in 1939 it attracted much attention, though no production of the metal is to be credited to that year. Chromium is one of the elements entering into many phases of modern commercial processes and at the present time is one of the metallic elements that the United States does not produce in sufficient quantities to meet its domestic needs. Deposits of chromium are known to occur at a number of places in Alaska, and from at least one of these considerable ore was shipped some years ago. This place is in the vicinity of Seldovia, near the southern tip of Kenai Peninsula. The two principal deposits at this place are at Claim Point and Red Mountain, both of which have been examined in some detail by geologists of the Geological Survey and had an estimate of their chromium content published.10 Late in 1939 the urgent need for adequate national defense led to the Government inviting bids for supplying some 25,000 tons of high-grade chrome ore. The successful bidder on this job proposed to furnish the ore from these Alaska deposits and on being awarded the contract began laying plans and making arrangements for carrying it out. By the time all the necessary negotiations were completed it was too late in the season of 1939 to set in motion any actual productive work that year, but there is every reason to expect that in 1940 the task of fulfilling the contract will be pressed vigorously.

Nickel is another of the metals that is of prime importance in military and industrial operations of national importance. It is also one of the materials with which the United States is not at present adequately supplied to meet its domestic needs. Consequently, there is at this time especially urgent call to seek out and determine whether or not there are domestic deposits that might relieve this national shortage. For a long time it has been known that there were occurrences of nickel ores in Alaska, but their real worth was not known with the degree of exactness that was required if a national policy was to be framed on their supposed availability or unavailability. One of these prospective areas was on Admiralty Island, and a Geological Survey party was dispatched in 1937 to study, among other things, the occurence of nickel there. Unfortunately the facts disclosed did not appear to warrant placing much dependence on this deposit as a source of much nickel for emergency

10 Gill, A. C., Chromite of Kenai Peninsula, Alaska: U. S. Geol. Survey Bull. 742, 52 pp., 1922. 
use. ${ }^{11}$ Another area in which nickel deposits have been known to occur is in the extreme western islands of southeastern Alaska, including Yakobi, Chichagof, and a belt that passes into Baranof Island. There is no question that nickel-bearing rocks occur there, but how much nickel they could furnish and their character are not adequately known. To determine these facts so far as practicable, a geologic party in charge of Mr. J. C. Reed was sent late in 1939 to make a start in the Yakobi-northern Chichagof Island area. This work was suspended in the fall and is to be resumed again in 1940. As yet the work has not been caried far enough to afford an answer to the question as to whether this part of Alaska can be looked to for supplying significant amounts of nickel to meet the Nation's needs.

Little new development is reported to have taken place in 1939 in mining the many kinds of nonmetallic mineral products that occur at various places in Alaska. Extensive use was made of the widespread gravel and rock deposits for railroad ballast and road construction, and with sand they entered largely into the concrete mixtures required in the more permanent structures that are beginning to be built in many parts of the Territory. In estimating the value of Alaska's mineral output in 1939 no value has been set on these materials, though if a price of only a few cents a ton had been placed on them, the output of mineral products would have been worth many thousand dollars more than the value stated. Necessarily many of these common materials are becoming of increasing importance as the development of the Territory progresses, and Alaska is fortunate in having widely scattered through its extent deposits of materials that can fill most of these needs as they arise.

11 Reed, J. C., Nickel content of an Alaskan basic rock: U. S. Geol. Survey Bull. 897-D, pp. 263-268, 1939. 



\section{INDEX}

P

Acknowledgments.

Admiralty-Alaska Gold Mining Co. operations by ...-...--

Admiralty Island, coal deposits on_..gold mining on.-_..nickel on

Aggie Creek, gold placers on_._-_...-

Ahtell Creek, gold placers on_-_-_-_--

Alaska Empire Gold Mining Co., operations by

Alaska Gold \& Metals Co., operations by

Alaska Gold Dredging Co., operations

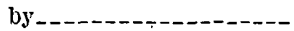

Alaska Hills Mining Co., operations by

Alaska Juneau Gold Mining Co., gold produced by _.-.--- 16-18

lead produced by

operations by

Perseverance property of, development of _._._. 17-18

silver produced by

Alaska-Pacific Consolidated Mining Co., operations by

Alaska Peninsula region, drilling for petroleum in

Alaska Placers Co., operations by

Alaska Railroad, coal for___._-__ 85-86, 87 user of coal

Alaska Range, antimony in northern foothills of

gold lodes on northern slopes of gold lodes on southern slopes of -gold placer's on northern flanks of -

gold placers on southern flanks of -

Alaska Range region, copper in

Alaska Sunset Mines Co., operations by Mining Corporation,

Alaska Taylor Mining Corporation, operations by.

Alatna River, gold placers on

Albert Creek, gold placers on--_-_---

Alder Creek, gold placers on

American Creek (Eagle district), gold placers on

American Creek (Hot Springs district), gold placers on --

American Creek (Kougarok district), gold placers on

American Creek Operating Co., operations by

American Tinfields, Inc., operations by

Ban

Bartholomae Oil Corporation, operations by -..--.-...---

Bear Creek (Fair'haven district), gold placers on -......-.--

Bear Creek (Kenai Peninsula district), gold placers on

Bear Creek ('Tuluksak-Aniak district),

gold placers on

Bear Creek Unit area, drilling for petroleum in ........---

Bering River field, coal deposits in ---

Bettles Bay mine, work on

Bettles River, gold placers on

Page

49

49

34

93-94

7

60

19

28

$20-21$

52

62

61

61

24

97

54

65

63

37

91

88

26

52

54

53

Big Eldorado Creek, gold placers on

Big Four mine, work on

Bird Creek, gold placers on

Black Gulch, gold placers on

Blue Jay mine, work at._._. 20

Bluff district, gold placers in _.___ 59,66

Bobtail Creek, gold placers on_-_-_-- 46

Bock claims; work on _._._. 47

Bonanza Creek (Chisana district), gold placers on 53

Bonanza Creek (Koyuk district), gold placers on

Bonasila Valley, gold placers in----- 46

Bonnifield district, gold placers in placer-gold production, totals_..- $\quad 39$

Boob Creek, platinum placers on --_-- 78

Bottom Dollar Creek, gold placers on_ 44

Boulder Creek (Hot Springs district), gold placers on_...-..- 47

Boulder Creek (Northwestern Alaska), gold placers on

Boundary Dredging Co., operations

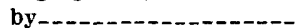


Bremner district, gold lodes in _...---

Bristol Bay Mining Co., operations by-_-_-_-_-

Broad Pass, gold lodes near

Budd Creek, prospecting in valley of Butte Creek, gold placers on Buzzard Gulch, gold placers on-_-_--

\section{$\mathrm{C}$}

Cache Creek (Hot Springs district), gold placers on--...--

Cache Creek (Yentna-Cache Creek district), gold placers

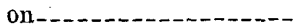

Cache Creek area, gold placers in ...

Cache Creek Mining Co., operations by

California Creek, gold placers on_-_--

Camel Gypsum Co., operations by -..-

Camp Creek, gold placers on_.....--

Candle area, gold placers in_.......-

Candle Creek (Fairhaven district), gold placers on

Candle Creek (Mount McKinley district), gold placers on--

Candle Creek area, gold placers in.-Canyon Creek (Fortymile district), gold placers on

Canyon Creek (Kenai Peninsula district), prospecting near.

Canyon Creek (Tuluksak-Aniak district), gold placers on

Cape Mountain, tin placers near...--

Caribou Creek (Fairbanks district), gold placers on_._._. 40,43

Caribou Creek (Kantishua district), gold placers on

Caribou Gold Dredging Co. (Fairbanks district), operations by-

Caribou Mines (Kantishna district), operations by

Casa De Paga Gold Co., operations by - 59-60

Casadepaga River area, gold placers

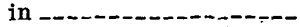

Chandalar district, gold placers in.placer-gold production, totals_...-

Chatanika River, gold placers on ----

Chena River, gold placers in valley of Chichagof district, gold lodes in _...

Chichagof Island, gold mining on ..gypsum deposits on -..........

Chichagoff Mining Co., operations by -Chicken Creek, gold placers on Chilkat Oil Co., operations by Chisana district, gold placers in -...-placer-gold production; totals_-.--

Chistochina district, gold placers in-platinum in

Chistochina River, Middle Fork of, gold placers on....-....

Chititu Creek, gold placers on

Chititu Mines, operations by Chromium, occiurrencel of Chulitna district, gold lodes in
Chulitna River, West Fork of, gold Pagø Cinnabar, occurrence of Circle district, gold placers in placer-gold production, totals--- $\quad 39$ Claim Point, chromium deposits at_- 96 Clara Creek Mining Co., operations by - 76-77 Cleary Creek, gold placers on Cleary Hill Mines Co., operations by _._Cleveland Peninsula, gold lodes on_- 19. Cliff mine, work on _..._._._._ 26 Coal, consumption of _._._-_- 85-86, 88-89 price of _._._. 86 problem concerning development. of

production of

Coal Creek, gold placers on ....... 43

Coffee Dome, gold placers near-_-_- 61

Cold Bay, drilling for petroleum in vicinity of _... 90

Colorado Creek, gold placers on_-_-_ 46 Conwest Exploration Co., operations by _._..... 20-21

Cook Inlet, drilling for petroleum on west coast of gold lodes near head of _._._. 20 Cook Inlet-Susitna region, gold placers in . gold produced in, totals Copper, ores yielding_..._ $72,73,77,79-81$ price of production of _._........... 12, 78-81 Copper River, petroleum east of mouth of 89

Copper River region, copper in gold lodes in 27 gold placers in gold produced in, totals_._._._. 32 platinum in Copper River Valley, gold placers in $33-34$ Council district, gold placers in_-- 59, 63-64 Council Dredging Co., operations by Coyote Creek, gold placers on _..._. 65 Craigie Creek, gold lodes on__-_._- 20-21 Cripple Creek (Fairbanks district), .. preparatory work for mining on

Cripple Creek (Innoko district), gold placers on

Cripple Creek Mining Co. (Innoko district), operations byCripple Creek Mountains, gold placers in vicinity of _. $45-46$

Crooked Creek, gold placers on _._._ 54 Crow Creek, gold lodes near head of_- 25-26 prospecting near head of._-_...-- $\quad 37$ Crow Creek Gold Corporation, operations by _._. Culross mine, work on

\section{D}

Dahl Creek (Kougarok district), gold placers on_._. 61

Dahl Creek (Northwestern Alaska), gold placers on.......-

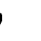


Dahl Creek Mining Co., opeiations by" Dall Island, limestone on Dan Creek, gold placers on Danicls Creek, gold placers on_-_...Deadwood Creek, gold placers on -..-Deadwood Mining Co.,. operations by - 40,43 Deep Creek, gold placers on Dese Creek, gold placers on Devault, Devault \& Leitz, operations by

Dick Creek, gold placers on Dime Creek, gold placers on platinum placers on

Dime Creek Dredging Co., operations by

Disappointment Creek, gold placers on

Discovery Gulch, gold placers on

Dome Creek (Fairbanks district), gold placers on

Dome Creek (Fortymile district), gold placers on

Donlin Creek, gold placers on

Dredges, length of working season of list of "one-bucket," description of placer gold mined by

Dry Creek Mining Co., operations by -Durand \& Awe Bros., operations by -.-

\section{E}

Đagle Creek, gold placer's on.

Engle district, gold placers in placer-gold production, totals...

Eldorado Creek, gold placers on Eska, Alaska Railroad coal mine at-Esperanto Creek, gold placers on_-.-Ester Creek, gold placers on_-_._-_Ester Dome area, gold lodes in Eureka Creek (Fot Springs district), gold placers on

Eureka Creek (Kantishna district), gold placers on

Eureka Creek area, gold placers in _...

Evan Jones Coal Co., operations by -- 86, 87

\section{$\mathrm{fF}$}

Fairbanks Creek, gold lodes near gold placers on

Fairbanks Creek area, preparatory work for mining in ---

Fairbanks district, gold lodes in gold placers in lode-gold production, totals..... placer-gold production, totals...-

Fairbanks Exploration Department. See United States Smelting, Refining \& Mining Co.

Fairhaven district, gold placers in --

platinum in

Fairview area, gold placers in....--

Faith Creek, gold placers on

Falls Creek, gold placers on
59 ,

Page

61
Fern Gold Leasing Co., operations

Pago

Fern mine, wor

First Chance Creek, gold placers on $\quad 40$

Fish Creek, gold placers on

preparatory work for mining on_- $\quad 41$

Fishbook Creek, gold lodes near head

Fitz Creek, drilling for petroleum near

Flagstaff Mining Co., operations by -- 19-20

Flat Creek (Iditarod district), gold placers on

Flat Creek (Marśball: district), gold placers in valley of

Flat Creek (Ruby district), gold placers on_-_-_-_-_-_ 49

Florida Creek, gold placers on

Folk bench claim, work on

Forsgren Dredging Co., operations by -- 62-63

Fort Gibbon district, gold placers in placer-gold production, totals__.- $\quad 39$

Fortymile district, gold placers in_-_- $\quad 48$ placer-gold production, totals___- $\quad \cdot 39$

Fortymile River, gold placers on_.... 48

Fourth of July Creek, gold placers on_- $\quad \mathbf{5 4}$

Fox Bar Dredging Co., operations by - $\quad 61$

Fox Creek, gold placers on_...... 54

\section{G}

Game Creek, gold placers nèar._...- 61

Ganes Creek, gold placer's on__-_._-- 45, 46

Garrison Co., operations by_._._. $\quad 57$

Gem Creek, gold placer's on .....- 61

Georgetown district, gold placers in _ 54-55, 56

Gertrude Creek, gold placers on

Gilmore Creek, gold placers on_-_-_- 40, 42

Gilpatrick mine, work on

Girdwood district, gold lodes in $-24-25,25-26$ gold placers in

Glen Gulch, gold placers on _..._._. 47

Gold, ores yielding price of _-_.-_- 12-13 production of

from lodes_..._._._._. 13, 15-28

from placers _._. 13, 15-16, 28-67

trend of value of

Gold Bullion mine, work on_._._._- 21

Gold Cord mine, work on

Gold lodes, production from, by districts_-_.-. 16-28

production from, summary of --- 13

trend of _........... 14

Gold placers, dredge mining of general conditions of mining of-- 28-31 production from, by districts_._- 31-67 summary off__-_._._.-. 13 trend of

Gold Run (Chisana district), gold placers on

Gold Run (Fairhaven district), pros: pecting on

Gold. Run (Port Clạrence diștricț), gold placers on

Gold Standard mine, work at

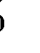

.

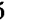

7

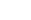

(3)

(1)

39

8

8

1

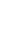

(1)

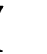

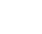

2

6

7

6

4

21

8

13

14


Golden Zone property, work on-..--

Goldstream Creek, gold placers on_-- 40,42

Goodnews. Bay, platinum in vicinity of - _-__- 76-77

Goodnews Bay Mining Co.; operations by _._ 58, 76-77

Goodnews district, dredging in gold placers in

Goodpaster district, prospecting work in

Goose Gulch, gold placers on Granite Creek (Ruby district), platinum placers on-..-.--

Granite Creek (Tuluksak-Aniak district), gold placers on--

Granite Creek (Yentna-Cache Creek district), gold placers on

Granite mine, work on

Granite Mountain, gold lodes on

Greenstone Creek, gold placers on---

Greenstone Mines, Inc. See Osborne Dredging Co.

Grubstake Creek (Bonnifield district), gold placers on

Grubstake Creek (Chistochina district), gold placel's on

Gypsum, occurrence of

\section{H}

Half Dollar Creek, gold placers on Hammond River, gold placers on Happy Creek (Fairbanks district), gold placers on

Happy Creek (Iditarod district), gold placers on

Hard, Uotila \& Hansen, operations by

Harrison Creek, gold placers on ...... Haycock area, gold placers in Healy River, coal in valley of

Healy River Coal Corporation, operations by--..-...--

Helm Bay, gold lodes near._._-_-- 19, 20

Hi Yu Mining Co., operations by .._- 22, 23

Hirshey property, work on

Hirst-Chichagof Mining Co., operations by

Hogatza River area, gold placers in $-52,53$

Holitna River, cinnabar deposits near mouth of

Holmes Gulch, gold placers on

Homestake Creek, gold placers on Hope Mining Co., operations by

Hot Springs district, gold placers in. placer-gold production, totals:-tin deposits in

Houston Fuel Co., operations by

Hunter Creek, gold placers on

Hyder district, gold lodes in lead in

\section{I}

Iditarod district, gold placers in. placer-gold production, totals_.-.Iditarod Mining Co., operations by -.-

Kas
(
Independence Creek, gold placers on-

Page

Independence mine, work on _._._.-_ 20-21

Indian River-Hughes area, gold placers in

Iniskin-Chinitna district, drilling for petroleum in

Iniskin Drilling Co., operations by --Inland Dredging Co., operations by --Inmachuk River, gold placers on Inmachuk Valley, gold placers in Innoko district, gold placers in placer-gold production, totals_-- $\quad 39$ platinum in _._._. 78 Innoko River, gold placers near head of -

Iridium. See Platinum.

Iron Creek, gold placers on

Iron Creek area, gold placers in Iyoukeen Cove, gypsum deposits in vicinity of

\section{$\mathbf{J}$}

Joe Creek, prospecting in valley of --Johnson \& Ostnes, operations by Joplin bench claim, work on Julian Creek, gold placers on Jump Creek, gold placers on Juneau district, coal deposits in _ 87-88 gold placers in 33

Jute Bay, drilling for petroleum in vicinity of

\section{$\mathbf{K}$}

Kahiltna River, platinum placers on Kako Creek, gold placers in vicinity of

Kantishna district, antimony ore in -gold lodes in gold placers in lead in placer-gold production, totals__- $\quad \mathbf{3 9}$ Karta Bay, gold lodes near._._._. 19-20 Kasaan Bay, gold lodes near._-_-_ 19 Kasaan Peninsula, platinum mines on $\quad \mathbf{7 7}$ Katalla district, petroleum in _..... 89 Keenan \& Castleton, operations by -.- 61 Kenai district, platinum in_..... 78 Kenal Peninsula, chromium deposits near southern tip of ...- 96 gold placers on Kenai Peninsula district, gold lodes in _...- 24-26 gold placers in $36-37$ Kenai River, prospecting in' valley of $\quad 37$ Ketchem Creek, gold placers on .... 44 Ketchikan district, copper in__._._ 79-80 gold lodes in limestone in ......... 94 platinum mines in Kiana area, gold placers in...... 67 Kimshan Cove, gold lodes near-_-- 18 Kirk, Morris P., \& Sons, Inc., operations by 93

Klag Bay, gold lodes near._._... 18 Klery Creek, gold placers in valley of

3

8

6

(1)

4


Kler'y Placers, Inc., operations by --_Kobuk district, lead in

Kobuk River Valley, gold placers in

Kodiak Island, gold placers on..... platinum placers on

Kokomo Creek, gold placers on

Kougarok Consolidated Placers, Inc., operations by .......-

Kougarok district, gold placers in $.59,60-61$

Kougarok River, gold placers on_...--

Kougarok Valley, gold placers in

Kow Kow Mining Co., operations by Kowkow Creek, gold placers on

Koyuk district, gold placers in platinum in

Koyukuk district, gold placers in placer-gold production, totals_..

Koyukuk Valley, gold placer's in .....

Kugruk River, conl deposits on prospecting on

Kuk Lagoon, coal along

Kuk River, coal deposits on .......

Kupreanof Island, gold lodes on

Kuskokwim region, cinnabar deposits

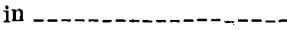
gold lodes in-_-_gold placers in gold produced in, totals

platinum in
Kuskokwim River, cinnabar deposits on

Kuskokwim Valley, cinnabar in gold lodes in gold placers in

Kvamme \& Co., operations by

\section{L}

Lake Iliamna, gold placers in vicinity of -

Lammers-Fitzpatrick Mining \& Exploration Co., operations by

Lead, ores of price of production of ....... 12,

Lee Bros., operations by Lillian Creek, gold placers on Limestone, occurrence of Little Creek, gold placers on Little Eldorado Creek (Chisana district), gold placers on

Little Eldorado Creek (Fairbanks district), preparatory work for mining on

Little Minook Creek, gold placers on_ Little Nugget Creek, prospecting in vicinity of

Little Squaw Creek, gold placers on Lituya-Yakataga district, gold placers

Livengood Creek, gold placers on

Livengood Placers, Inc, operations by Long Creek, gold placers on_-_-_--_ Long Creek Mining Co., operations by Lost Chicken Creek, gold placers on--
Page
Lucky Creek, gold placers on

Lucky Gulch (Kantishna district), gold lodes near head of -

Lucky Gulch (Valdez Creek district), gold placers on

Lynx Creek, gold placers on

\section{M}

Mabel mine, work on

McCarty mine, work on

McCaskey Bar, gold placers on

McGowan \& Lind, operations by -.--

McLean Arm, gold lodes near

Mahan \& Slack, operations by _...- 66

Maid of Mexico mine, work on _-_.- 20

Mammoth Creek, gold placers on_.._ 43, 44

Marguerite Creek, gold placers on_--- 51

Mairshall district, gold placers in _-_.- 46-47 placer-gold production, totals_._- $\quad 39$

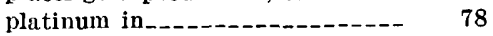

Marvel Creek, gold placers on _..._. 57

Marvel Creek Mining Co., operations by

Marvel Dome, gold placers in vicinity of

Mascot Mining Co., operations by _-- $\quad 61$

Mastodon Creek, gold placers on _._._ 44

Mastodon Dome, gold placers near-_-_ $\quad 43$

Matanuska field, coal in_..._._._. 86, 87

Matheson \& Savage, operations by ... $\quad 46$

Mayfield mine, work on._._._._. 26

Medfra area, gold placers in_._._._ 55, 56

Mercury. See Cinnabar.

Mespelt \& Co., operations by

Metal Creek, platinum placers on

Middle Fork, gold placers on _._-_ $\quad \mathbf{5 2}$

Middle Fork Mining Co., operations by 34

Miller Creek, gold placers on_-_-_- 44

Miller Gulch, gold placers on_._._.- $\mathbf{3 4}$

Mills Creek, gold placers on

Mineral Creek, gold lodes on__-_-_-_ 26-27

Mineral production, assembling of statistics general features of summaries of trends of _... 11

Mineral products, miscellaneous, value . of - $10-12$

Minerals, prices of _._._. 6-7

Minook, Ltd., operations by _....... $\quad 53$

Mohawk Mining Co., operations by _.- 23

Monarch-Jewel mine, work on _.__ 25-26

Montana Mining Co., operations by-- 47

Monument Creek, gold placers on _._- 59-60

Moore Creek area, gold placers in

Moore Creek Mining Co., operations by - 55-56

Moose Creek (Kantishna district), gold placers on

Moose Creek (Ruby district), gold placers on

Moose Pass-Hope district, gold lodes 
Moose Pass Placers, Inc., operations by:-

Mosquito Fork, gold placers on Mount McKinley district, gold placers in

Myers Fork Creek, gold placers on:-Myrtle Creek, gold placers on_._-_.--

\section{$\mathbf{N}$}

Nabesna district, lode-gold production, totals

Nabesna Mining Corporation, operations by _-__:- 23-24, 79-80

Nabesna River, copper in valley of gold lodes in valley of _._._._. 23-24

Nearhouse property, work on_-_-_-Nelchina district, gold placers in.-.Nelson \& Tift, operations by -..-.--

Nelson Mining Co., operations by -..-

Nenana field, coal in _..............

New Hope property, work on

New York-Alaska Gold Dredging Co., operations by _..- 56-57

Nickel, occurrence of

Nickoloff property, work on_._-_--Nicolai Placer Mines, operations by-Niukluk River, gold placers on Nixon Fork district, gold lodes in Nixon Fork mine, work on

Nixon Fork. Mountains, gold placers on flanks of -.....-..-

Nizina district, gold placers in-_-_-Nolan Creek, gold placers on ........

Nome Creek, gold placers on

Nome district, gold placers in
North American Dredging Co., opera-

North American Dredging Co., opera
tions by

North American Mines, Inc., operations by

North Star Dredging Co. See Alaska Placers Co.

Northern Alaska, coal in

Northern Commercial Co., operations by _....................

Northland Development Co., operations by -.........

Northwestern Alaska, gold placers in_

gold produced in, totals......-

Norton Bay, gold placers east of

Nugget Creek, gold placers on -.-----

Nuka Bay district, gold lodes in...-.

Nukalaska Mining Co., operations by

\section{o}

Offield Creek, gold placers on Oil. See Petroleum.

Olive Creek, gold placers on Olson \& Co., operations by

Omega Creek, gold placers on

Omilak mine, lead ores from

Ophir Creek (Council district), gold placers on

Ophir Creek (Innoko district), gold placers on

Oracle mine, work on
37.

48

55-56

48

52

16

25

Page

Osborn Creek, gold placers on Osborne Dredging Co., operations by- 59-60 Osmium. See Platinum.

Otter Creek, gold placers on_-_._-_._ 44, 45

\section{$\mathbf{P}$}

Pacific Coast Cement Co., operations

$$
\text { by - }
$$

Palladium. See Platinum.

Palmer Creek (Fairbanks district), gold placers on

Palmer Creek (Kenai Peninsula), gold lodes near.....-. 25

gold. placers on

Pass Creek, gold placers on

Patterson Creek, gold placers on_._._ 62

Pearl Creek, gold placers on _.._-_. $\quad 40$

Pedro Creek, gold placers on ..._._. 40

Pedro Dome area, gold lodes in

Peters Creek, gold placers on

Peterson \& Mayfield, operations by--- $\quad 37$

Petroleum, consumption of _._._._- 89-90 production of prospecting for

Pinnell River, gold placers on

Pioneer Creek, gold placers on _.... 47

Platinum, price of production of _._._._._._._ 12,75-78

Poorman Creek (Ruby district), gold placers on

Poorman Creek (Yentna-Cache Creek district), gold placers on

Porcupine Creek, gold placers on _..-_ 44

Porcupine district, gold placers in _-_ 33

Port Clarence district, gold placers in _._- $59,64-65$

Portage Bay Mining Co., operations by-_...- 26

Portage Creek (Bonnifield district), gold placers on

Portage Creek (Circle district), gold placers on

Portage Creek (Kenai Peninsula), gold placers on

Portland Canal, gold lodes near head of -

Potato Mountain, tin deposits near... 84

Prince of Wales Island, copper on gold lodes on_._._. 19-20 quarries on west coast of _._._._. 95

Prince William Sound region, gold lodes in _..._..... 24, 26-27 Publications, selected list of

Quail Creek, gold placers on-_-_-_- $\quad 53$

Quartz Creek . (Fairhaven district), gold placers on

platinum placers on

Quicksilver. See Cinnabar.

\section{$\mathrm{R}$}

Rampart district, gold placers in -..- 53 placer-gold production, totals_-- $\quad 39$

Ramsey-Rutherford mine, work on 
Reconstruction Finance Corporation, aid from__._. $48-49$

Red Mountain (Goodnews district), platinum deposits near.

Red Mountain (Kenai Peninsula), chromium deposits at_-

Red River, gold placers near.-_-_---

Red Top Mining Co., operations by ---

Resurrection Creek, gold placers on---

Revillagigedo Island, gold lodes on

Rex Creek (Bonnifield district), gold placers on

Rex Creek (Nizina district), gold placers on

Rhode-Island Creek, gold placers on_ Rhodium. See Platinum.

Riley, J. E., Investment Co., operations by

Riley Creek, gold placers on

Ruby district, gold placers in-----placer-gold production, totals

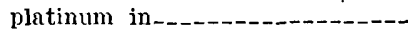
tin deposits in Russian Mission, gold placers near.Ruth Creek, gold placers on Ruthenium. See Platinum.

\section{S}

St. Michael Creek, gold placers on

St. Patrick Creek, gold lodes near head of _....................

Salmon Creek, drilling for petroleum at head of

Schwaesdall \& Repo, operations by.-

Seventymile River, gold placers in valley of

Seward Peninsula, coal deposits on gold placers on gold produced in, totals lead on-_-_-_platinum on-_............... prospecting work on tin deposits on Seward Placer Co., operations by Shamrock Creek, gold placers on_...Sheep Creek, prospecting in vicinity of Shungnak area, gold placers in Shungnak River, gold.placers on Silver, ores of price of production of

Silver's prospect, prospecting on

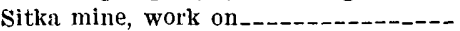
Sixmile River, prospecting on Slate Creek (Christachina district), gold placers on

Slate Creek (Iditarod district), gold placers on _......-.

Slate Creek (Koyukuk district), gold placers on

Slate Creek Placers, Inc, operations by

Snake River (Nome district), gold placers in valley of ----

Snake River (Seward Peninsula), gold lodes near head of
Page

Snow Gulch, gold placers on

Solomon district, gold placers in

Solomon River, gold placers on
77

96

37

24

6-37

19

51

34

47

44
Sonny Fox Mining Co., operations by Sources of information_._-_._-_- 1-4

Sourdough Creek, gold placers on $-40,42-43$

Southeastern Alaska, copper in -..-- 79-80 gold lodes in gold placers in gold produced in, totals_._._._._ 16,32 lead in limestone in marble in nickel in -._._-_._- 97 platinum mines in_._-_._-_._- $\quad \mathbf{7 7}$

Southern Cross mine, work on

Southwestern Alaska, gold placers in.. $\quad 35$ gold produced in, totals_._._._. 16,32 platinum in

Spaulding Creek, gold placers on_---- 46

Specimen Gulch, gold placers near---- 60

Spokane-Peters Mining Co., operations by

Spruce Creek (Innoko district), gold placers on

Spruce Creek (Ruby district), gold placers on

Squirrel River, gold placers in valley of

Stampede Creek, antimony ore on -.-

Standard Oil Co. of California, operations by

Stuyahok Valley, gold placers in Sullivan Creek, gold placers on .....Sunset Creek (Nome district), gold placers on

Sunset Creek (Port Clarence district). gold placers on

Superior Portland Cement, Inc., operations by

Susitna region, platinum in Susitna River, gold placers near head of -

Swede Creek, gold placers on Swede Creek Mining Co., operations by

Sweepstake Creek, gold placers on Switch Creek, gold placers on_-_._-_-

\section{T}

Tamarack Creek, gold placers on-.-Tanana River, gold placers in vicinity of -

Thorne Arm, gold lodes near.....Three Miner's, Inc., operations by -..Tibbs Creek, gold lodes in vicinity of Tide Water Associated Oil Co., operations by

Timber Creek, gold placers on Timber Creek Mining Co., operations by Tin, price of production of Tobin Creek, prospecting on _._._. 54 Tofty area, gold placers in 28 Tokichitna River, gold placers on__-_ 36

\section{(n)}

象


Tolovana district, gold placers in placer-gòld production, totals_...

Tolstoi area, platinum in

Too Much Gold Creek, gold lodes on -

Topkok Chief Mining Co., operations by

Totatlanika River, gold placers on

Trail Creek, gold placers on-_._..--

Tramway Bar, gold placers on

Triple X Placers, operations by
Troublesome Creek area, gold placers

Troublesome Creek area, gold placers

Tuluksak-Aniak district, gold placers in -

Tunnell Mining Co., operations by --Tweet, N. B., \& Sons, operations by -

Twelvemile Arm, gold lodes near.-.--

\section{$\mathrm{U}$}

Ungalik area, gold placers in Ungalik River, gold placers on Ungalik Syndicate, operations by -..Union Oil Co. of California, operations by

United States Smelting, Refining \& Mining Co., Fairbanks Exploration Department, length of working season

Fairbanks Exploration Department, operations by

$40-42,44,53$

user of coal

Nome Department, length of working season operations by

Uotila \& Haid, toperations by

Uotila \& Ogriz, operations by

Upper Koyukuk area, gold placer's in

Utopia Creek, gold placers on_-_-_---

\section{$\mathrm{V}$}

Valdez Creek, gold placers on_._._-_Valdez Creek district, gold placers in Vault Creek, gold placers on Vermont Marble Co., operations by --Vibe \& Schwaesdall, operations by-..w

Wade Creek, gold placers on
Page

48-49

39

78

23

66

51

49-50

52 .

$50-51$

53

36
65

19

64

64
64

64
64

64

91

1$$
\text { W }
$$

70

22 ,

86

70

59

46

45

52

52

36

35,36

40

95

46

48
Walkér Fork, gold placers on

Walker Fork Dredging Co., operations by

Wattamuse Creek, gold placers on -

Wells Bros. prospect, work on

White Creek, gold placers on

Wilbur Creek, gold placers near.-_--

Wild River, gold placers on

Willow Creek (Iditarod district), gold placers on_--_----

Willow Creek (Marshall district), gold placers on

Willow Creek (Mount McKinley district), gold placers on --

Willow Creek (Yentna-Cache Creek district), gold placers on

Willow Creek district, gold lodes in $-20-22$ lode-gold production, totals_-_-- 16

Willow Creek mine, work on -._-_-_- 20-21

Wilson Creek Mining Co., operations by

Wolf Creek (Eagle district), gold placers on

Wolf Creek (Fairbanks district), gold placers on

Woodchopper Creek (Circle district), gold placers on

Woodchopper Creek (Hot Springs district), gold placers on-

Wrangell district, gold lodes in...-. $\mathbf{Y}$

Yakobi-northern Chichagof Island area, nickel_in_._._._. 97

Yankee Creek, fgold placers on

Yellow Band Gold Mining Co., Inc., operations by .....-

Yentna-Cache Creek district, gold placers in -

Yentna district, platinum in._.... 78

Yukon Basin, gold produced in, totals_ $\quad 32$

Yukon Mining Co., operations by --- $46-47$

Yukon region, gold placers in_-__- 38-54 platinum in.............. 78

Yukon River, gold placers in vicinity of _... 54

Yukon-Tanana region, lead in tin deposits in 83

83

8
4 